\title{
Concentração de hemoglobina em crianças de 6 a 36 meses, antes e depois de sua inscrição no Projeto Estadual do leite - VIVALEITE
}

\section{ANA CAROLINA ENCISO DE SÁ}

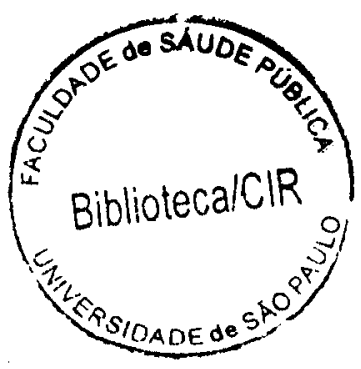

Dissertação apesentada ao Programa de PósGraduação em Saúde Pública da Faculdade de Saúde Pública da Universidade de São Paulo para obtenção do título de Mestre em Saúde Pública.

Área de Concentração: Nutrição

Orientadora: Profa. Dra. Sophia C. Szarfarc

\section{São Paulo}

2005 
Autorizo, exclusivamente para fins acadêmicos e científicos, a reprodução total ou parcial desta dissertação, por processos fotocopiadores.

Assinatura:

Data:

$$
4674 \text { 21000 dox }
$$




\section{AGRADECIMENTOS}

À minha orientadora, Profa Sophia C. Szarfarc, pelos conhecimentos transmitidos, pela paciência, compreensão e dedicação. Além de excelente profissional, uma pessoa admirável. Agradeço por todos os momentos bons que passamos juntas.

À Prof Josefina Ap. Pellegrini Braga, pelo auxilio, pela atenção, e pelo carinho e cordialidade, sempre presentes.

À Dra Silvana Maria F. Margatho, pela atenção e carinho dispensados, além do sempre presente incentivo quanto ao trabalho acadêmico.

A todos os amigos da CODEAGRO, especialmente à Rosângela Ap. Augusto, indispensáveis para a realização deste trabalho.

À Dra Maria Lúcia Rosa Stefanini, por todas as informaçōes compartilhadas e pela atenção dispensada.

Ao meu pai José Francisco de Sá e à minha mãe Imaculada de Sá, por terem sempre zelado por minha educação e formaçăo, pela paciência nos momentos difíceis, pelo apoio e estímulo, e por serem o alicerce da minha vontade de crescer e alcançar novas conquistas.

Ao meu namorado Marcelo Assumpçăo, pelo companheirismo e apoio em todos os momentos da minha vida.

À minha amiga e futura sogra Maria Elena Criscio, pela correção gramatical do meu trabalho, mas, principalmente pelo apoio, amizade e carinho que tanto prezo. 


\section{RESUMO}

Sa ACE. Concentraçăo de hemoglobina em crianças de 6 a 36 meses, antes e depois de sua inscriça no Projeto Estadual do leite - Vivaleite. São Paulo; 2004. [Dissertaçăo de mestrado - Faculdade de Saúde Pública/Universidade de São Paulo].

Objetivo: Comparar os valores médios de hemoglobina, antes e após 6 meses de consumo de leite do Projeto VIVALEITE. Metodologia: $O$ estudo foi realizado em Itapeva, Piracicaba, Săo José dos Campos, Taubaté e São Paulo, locais selecionados devido ao aumento representativo do número de crianças beneficiadas pelo Projeto. A amostra foi constituída de 399 crianças, de 6 a 36 meses de idade. Os dados da criança e da família foram obtidos mediante aplicação de formulário. O diagnóstico da anemia foi efetuado por meio da dosagem de hemoglobina, utilizando-se o aparelho HemoCue $^{\star}$. O valor critico utilizado para caracterização de anemia foi de $11,0 \mathrm{~g} / \mathrm{dL}$ e os níveis médios de concentração de hemoglobina foram comparados pelo Teste T Pareado e pela Análise de Variância (ANOVA), com nível de significåncia de 5\%. Resultados e Discussāo: Foi encontrada uma diferença significativa $(p=0,0)$ entre as concentrações de hemoglobina antes $(10,18 \mathrm{~g} / \mathrm{dL})$ e após o consumo do leite do VIVALEITE $(10,99 \mathrm{~g} / \mathrm{dL})$, verificando-se um incremento de $0,81 \mathrm{~g} / \mathrm{dL}$ nos índices de hemoglobina. No início do acompanhamento, $67,9 \%$ das crianças apresentavam anemia, e ao final do acompanhamento, esse valor decresceu para $48,7 \%$, ou seja, $18,5 \%$ do total de crianças estudadas saíram do estado anêmico, sendo esse valor estatisticamente significante $(p=0,0)$. Conclusōes: Está bem documentada a eficiência da intervenção proposta pelo VIVALEITE no controle da deficiéncia marcial, desde que essa açăo seja somada de orientação nutricional constante, como a aplicada neste trabalho. Além disso, há necessidade de uma revisão, no que diz respeito à operacionalização do Projeto, no sentido de aprimorar os seus efeitos na saúde da criança.

Descritores: Anemia ferropriva, Ferro quelato, Leite fortificado, Projeto VIVALEITE, Suplementaçăo alimentar. 


\begin{abstract}
Sa ACE. Hemoglobin levels in children from 6 to 36 months, before and after their introduction on Estate Project - VMALETTE. São Paulo; 2004. [Dissertaçăo de mestrado - Faculdade de Saúde Pública/Universidade de São Paulo].
\end{abstract}

Objective: To compare the average values of hemoglobin, before and after six months of consume of VIVALEITE milk. Methodology: The present study was development in Itapeva, Piracicaba, São José dos Campos, Taubaté and Săo Paulo cities. These places were chosen because of the represented increased of number of children that will be matriculated on VIVALEITE. Three thousand and ninety nine children between six and twenty four years old were included in the study. A form was fill to obtain the family and children characteristics. The anemia diagnosis was made by the dosage of hemoglobin concentration in blood, through digital puncture and the reading was made by the HemoCue ${ }^{\circ}$. The critical value adopted by this study for anemia diagnosis was $11,0 \mathrm{~g} / \mathrm{dL}$. Statistical analyses used the Student $t$ test, Variance analyses and $X^{2}$, with $p<0,05$. Results and Discussions: This study found a significant difference $(p=0,0)$ between hemoglobin levels before $(10,18 \mathrm{~g} / \mathrm{dL})$ and after $(10,99 \mathrm{~g} / \mathrm{dL})$ six months of consume of fortified milk (VIVALEITE milk). There was an increase of $0,81 \mathrm{~g} / \mathrm{dL}$ in children hemoglobin levels. At the beginning of study, $67,9 \%$ of the children presented anemia. After six months, this percentage had decreased to $48,7 \%$. Therefore, $18,5 \%$ of children recovered of anemia status, and this value was statistically significant $(p=0,0)$. Conclusions: The effectiveness of food fortification for anemia of iron deficiency treatment is very well established by the literature and this is the proposal of VIVALEITE Project. Nevertheless, there are needs of changes in the operacionalization of the Project to accomplish their objectives and to promote good results for the children's health.

Describers: Anemia for iron deficiency, Food Fortification, Fortified milk, Quelated iron, State Project - VIVALEITE. 


\section{LISTA DE TABELAS}

1 Distribuiçăo das perdas na amostra, segundo local de estudo. São Paulo, 2003-2004.

2 Distribuiçăo do $n^{\circ}$ e \% de crianças, segundo características da familia. Săo Paulo, 2003-2004.

3 Distribuiçăo do $\mathrm{n}^{\circ}$ e \% de crianças, segundo recebimento de programas assistenciais. Săo Paulo, 2003-2004.

4 Distribuiçăo do $n^{\circ}$ e \% de crianças, segundo suas características. São Paulo, 2003-2004.

5 Distribuiçăo do $n^{\circ}$ e $\%$ de crianças, segundo consumo de sulfato ferroso. Săo Paulo, 2003-2004.

6 Médias de hemoglobina, peso ao nascer, desmame e consumo de leite no início do acompanhamento. Såo Paulo, 2003-2004.

7 Distribuiçăo das crianças, segundo média de consumo diário de leite por idade, relatado pela mảe ou responsável, no início do acompanhamento. Săo Paulo, 2003-2004.

8 Distribuiçăo do $n^{\circ}$ e \% de crianças, segundo consumo de leite no início 58 do acompanhamento. São Paulo, 2003-2004.

9 Distribuiçăo do $n^{\circ}$ e \% de crianças, segundo consumo de leite (VIVALEITE ou outro) ao final do acompanhamento. São Paulo, 20032004.

10 Distribuiçăo do $n^{\circ}$ e $\%$ de crianças, segundo consumo de leite (não VIVALEITE) ao final do acompanhamento. Săo Paulo, 2003-2004.

11 Distribuiçăo do $n^{\circ}$ e \% de crianças, segundo consumo de leite do VIVALEITE pelo beneficiário, relatado pela måe ou responsável, ao final do acompanhamento. Săo Paulo, 2003-2004.

12 Consumo de leite do VIVALEITE por crianças beneficiárias (ao final do acompanhamento), segundo relato da măe ou responsável. São Paulo, 2003-2004.

13 Distribuiçăo do $n^{0}$ e $\%$ de crianças, segundo consumo semanal de alimentos fonte de ferro. Săo Paulo, 2003-2004. 
14 Distribuiçăo do $n^{\circ}$ e $\%$ de crianças, segundo consumo de VIVALEITE por membros da família (excluindo-se a criança beneficiária) - diluição intrafamiliar. Săo Paulo, 2003-2004.

15 Distribuição das crianças, segundo prevalência de anemia por faixa etária, ao inicio e ao final do acompanhamento. São Paulo, 2003-2004.

16 Distribuiçăo do $n^{\circ}$ e \% de crianças, segundo hábito de ferver o leite, antes e depois de orientaçăo. Săo Paulo, 2003-2004.

17 Distribuiçăo do $n^{\circ}$ e $\%$ de crianças, segundo hábito de descartar a nata, antes e depois de orientaçăo. Săo Paulo, 2003-2004.

18 Distribuiçăo do $n^{\circ}$ e \% de crianças, segundo características da populaçăo e concentração de hemoglobina, no início do acompanhamento. Săo Paulo, 2003-2004.

19 Distribuiçăo do $n^{\circ}$ e $\%$ de crianças, segundo concentração de hemoglobina e consumo diário de leite relatado pela mãe ou responsável, no início do acompanhamento. São Paulo, 2003-2004.

20 Distribuição do $n^{\circ}$ e $\%$ de crianças, segundo concentração de hemoglobina por faixa etária, no inicio do acompanhamento. São Paulo, 2003-2004.

21 Distribuição do $n^{\circ}$ e $\%$ de crianças, segundo concentração de hemoglobina e volume de leite do VIVALEITE, referido pelas mães ou responsáveis. Săo Paulo, 2003-2004.

22 Distribuiçăo do $n^{\circ}$ e \% de crianças, segundo concentração de hemoglobina por faixa etária, ao final do acompanhamento. São Paulo, 2003-2004.

23 Distribuiçăo das crianças, segundo média de concentraçăo de hemoglobina no inicio e ao final do acompanhamento. São Paulo, 2003-2004.

24 Distribuiçăo do $n^{\circ}$ e \% de crianças, segundo concentração de hemoglobina no inicio e ao final do acompanhamento. São Paulo, 2003-2004.

25 Distribuiçăo das crianças, segundo concentraçăo de hemoglobina no início e ao final do acompanhamento. São Paulo, 2003-2004. 


\section{LISTA DE QUADROS, GRÁFICOS E FIGURAS}

\section{QUADROS}

No

1 Recomendaçōes diárias de ferro.

Fonte: RDANRC (1989).

2 Consumo diário de ferro e \% de adequação por crianças. São 27 Paulo. 1984/85.

Fonte: MONTEIRO (1988).

3 Niveis de hemoglobina indicativos de anemia.

Fonte: DEMAYER (1989)

4 Distribuição da população amostral, segundo local de estudo. 39 São Paulo, 2003-2004.

$5 \quad$ Média de consumo diário de leite por crianças. São Paulo. 58 2002

\section{GRÁFICOS}

$\mathbf{N}^{\mathbf{0}}$

1 Distribuição das crianças, segundo idade de desmame. São Paulo, 2003-2004.

2 Distribuição das crianças, segundo prevalência de anemia no 56 inicio do acompanhamento. São Paulo, 2003-2004.

3 Distribuição das crianças, segundo prevalência de anemia no 65 início e ao final do acompanhamento. São Paulo, 2003-2004.

\section{FIGURA}

$\mathbf{N}^{\circ}$

1 Fluxograma de adição de ferro ao leite

Fonte: SOGLIA (2001). 


\section{SUMÁRIO}

Página

1. INTRODUÇĀO

1.1. Breve histórico sobre Programas Govemamentais de combate às caréncias nutricionais

1.2. Projeto Estadual do Leite - VIVALEITE

9-14

1.3. Ferro e deficiência

1.4. Anemia 23-32

1.5. Fortificaçăo de alimentos

2. JUSTIFICATIVA DO TRABALHO 35-36

3. OBJETIVOS

3.1. Objetivo Geral

3.2. Objetivos especificos

4. MATERIAL E MÉTODOS

4.1. Aspectos éticos da pesquisa 38

4.2. Delineamento, Local e Populaçăo do estudo $38-40$

4.3. Obtenção dos dados 40

4.4. Variáveis 41

4.5. Categorizaçăo das variáveis $42-48$

4.6. Dosagem da concentraçăo de hemoglobina 48

4.7. Orientaçăo Nutricional 48-49

4.8. Digitaçăoo dos dados 49

4.9. Análise de dados 49 
5.1. Caracterizaçăo das familias do Projeto VIVALEITE

5.2. Caracterizaçăo das crianças do Projeto VIVALEITE

5.3. Verificaçăo da adesão à orientaçăo nutricional

5.4. Comparaçסes entre a concentração de hemoglobina e as características da populaçăo estudada

5.5. Comparaçס̃es entre a concentraçăo de hemoglobina, no início e ao final do acompanhamento.

5.6. Consideraçס̄es sobre o Projeto Estadual do Leite - VIVALEITE.

6. CONCLUSÃO

Consideraçōes finais

7. REFERÊNCIAS BIBLIOGRÁFICAS

\section{ANEXOS}

ANEXO 1: Operacionalização do Projeto VIVALEITE

ANEXO 2: Termo de consentimento

ANEXO 3: Questionário às mães ou responsáveis pela criança

ANEXO 4: Termo de encaminhamento

ANEXO 5: Orientação Nutricional

ANEXO 6: Folder 


\section{INTRODUÇÃO}

A alimentaçăo adequada é um direito humano básico, reconhecido no Tratado Intemacional de Direitos Humanos, Económicos, Sociais e Culturais. Quando este direito nāo é assegurado, surgem as carências nutricionais, que se expressam, principalmente, através da anemia ferropriva e da desnutrição energético-protéica (DEP) (VALENTE 2001).

As crianças dos paises em desenvolvimento são as principais vitimas das carências nutricionais que, em última análise, acabam atuando como obstáculos para o desenvolvimento, destacando-se os custos envolvidos com as conseqüências dessas carências e de suas complicações, 0 comprometimento do aprendizado e as limitaçōes decorrentes, na idade adulta, na produtividade da força de trabalho (MONTEIRO 1988).

Nas últimas décadas, a distribuiçăo de alimentos para grupos populacionais vulneráveis tem sido apontada, freqüentemente, como um componente importante das estratégias voltadas para a melhoria das condiçőes de vida e saúde nos paises nảo desenvolvidos (UNICEF 1998; GHASSEMI 1992a, b).

\subsection{Breve histórico sobre Programas Governamentais de combate às carências nutricionais}

A primeira iniciativa do govemo brasileiro, no sentido de intervir no combate às caréncias nutricionais, teve início em 1938 com o estabelecimento do salário mínimo, seguida, na década de 40 , pela criação de diversos órgăos que tinham, entre outros objetivos, o de auxiliar o governo na formulaçăo de politicas de alimentaçăo e nutrição (CAVALCANTI e RIBEIRO 2003).

O programa de distribuiçăo de leite da Secretaria de Estado da Saúde de Săo Paulo (SES-SP) teve início na década de 50 e foi um dos programas de suplementação alimentar introduzidos no $1^{\circ}$ Plano Nacional de Alimentaçăo do Brasil, apresentado pela Comissão Nacional de Alimentaçăo, na $3^{\mathbf{a}}$ Conferência Latinoamericana de Nutrição, realizada na 
Venezuela, em 1953. Nessa oportunidade foram implantados programas de ajuda alimentar, por meio da Organização das Naçōes Unidas para a Agricultura e Alimentaçăo (FAO) e do Fundo das Nações Unidas para a Infância (UNICEF). O UNICEF patrocinou a distribuição de leite voltada para o grupo materno-infantil, na maioria dos países latinoamericanos (retirando, tal ajuda, na década de 60.) No Brasil, esse programa foi coordenado pela Comissăo Nacional de Alimentaçăo. Inicia-se, então, a distribuição de leite em po, modificado (maternizados, acidificados, adicionados de ferro, etc) ou năo, nas unidades de saúde (STEFANINI 1994).

A década de 70 caracterizou-se pela expansão do conhecimento nos campos da epidemiologia social, das políticas públicas e da nutrição. Surge, então, o Instituto Nacional de Alimentaçăo e Nutrição (INAN) (STEFANINI 1994).

O INAN, vinculado ao Ministério da Saúde, tinha por objetivo propor o Programa Nacional de Alimentaçăo e Nutriçăo - PRONAN, promover e fiscalizar a sua execução, e avaliar os resultados. Embora situada como atividade emergencial e transitória, a suplementação alimentar constituiu-se, a partir de então, em parte central do conjunto de açōes propostas pelo govemo para o controle da desnutriçăo, através dos diversos programas criados pelo INAN (MONTEIRO 1998).

Por meio do PRONAN intensificaram-se os diagnósticos nutricionais e de saúde. Um grupo formado por lideranças da pediatria e nutriçăo propõe a substituiçăo dos leites modificados distribuidos nos postos de saúde por leite integral, fundamentada em justificativas técnicas e económicas (STEFANINI 1994).

O PRONAN desenvolveu uma das ações de atenção à saúde das crianças embasado no combate à desnutriçăo das gestantes e nutrizes, a partir do ano de 1973, estendendo-se até 1979. Outro programa, o Plano de Nutrição e Saúde (PNS), foi implantado em todos os estados da federação, a partir de 1975, e consistiu na suplementaçăo alimentar de gestantes, nutrizes e crianças de 6 meses a 6 anos de idade, da população com renda abaixo de 2 salários mínimos. As crianças de 6 a 24 meses recebiam, 
mensalmente, 1 quilo de leite desnatado em pó, 2 quilos de açúcar e 1 quilo de arroz. (CAVALCANTI e RIBEIRO 2003).

Em meados da década de 70 foi elaborado um programa destinado à suplementaçăo alimentar de gestantes, nutrizes e crianças inscritas na rede de unidades sanitárias da SES-SP, por meio do Programa de Assistência Materno Infantil (AMI). Até 1970, o AMI só atendia crianças de 0 a 12 meses, pertencentes a famílias comprovadamente carentes, inscritas no programa. Estas recebiam leite em pó (integral e alguns tipos de leite modificado) e produtos a base de soja. Deve-se lembrar que, no início da década de 70, 0 Brasil começou a desenvolver o plantio de soja, ofertando-a no mercado interno e externo. A partir de 1976, o programa incluiu o atendimento a gestantes, nutrizes e crianças de até 18 meses que apresentassem sinais de má nutriçăo. Cada criança recebia 4 latas (de $459 \mathrm{~g}$ cada) ou 2 pacotes ( $1000 \mathrm{~g}$ cada) de leite em pó por mês. As crianças de 4 a 6 meses recebiam outros alimentos (sopas, frutas, mingaus), gradativamente, em complementaçăo ao leite matemo ou ao leite em pó (CAVALCANTI e RIBEIRO 2003). Entre 1977 e 1980 triplicou a demanda no fornecimento de leite, seguida pelo aumento nos preços do produto praticados pela indústria, estrangulando o orçamento da SES-SP. Assim, em 1984, foi lançado o Programa de Leite Fluido para libertar o setor público da politica de preços das indústrias, viabilizar a continuidade da distribuiçăo e favorecer as cooperativas leiteiras (STEFANINI 1994).

Paralelamente, em 1976, foi implantado o Programa de Suplementaçăo Alimentar para gestantes, nutrizes e crianças de até 6 anos de idade, denominado "Pró-Nutri", pela Secretaria de Promoção Social do Estado. No mesmo período, a Prefeitura do Município de São Paulo também forneceu leite em pó em seus postos de saúde, através do Programa de Distribuiçăo de Leite na Rede de Saúde (CAVALCANTI e RIBEIRO 2003).

Portanto, de 1976 a 1985, houve vários programas de suplementação alimentar, promovidos pelos govemos Federal, Estadual e Municipal, com os mesmos objetivos, mas atuaçōes diferentes (CAVALCANTI e RIBEIRO 2003). 
Em 1985 foi criada a Secretaria Especial de Ação Comunitária e lançado o Programa Nacional do Leite para Crianças Carentes (PNLCC), onde as organizaçőes comunitárias previamente credenciadas distribuiam cupons trocados no varejo, por 1 litro de leite para cada criança menor de 7 anos de idade, pertencente a familias com renda mensal menor que 2 salários mínimos. Este programa, que atendia a 7,8 milhōes de crianças em 1989, foi extinto em 1990 (STEFANINI 1994).

Em decorrência do Movimento Sanitário, o Sistema de Saúde sofreu importantes modificaçőes que se consolidaram na $8^{\mathbf{a}}$ Conferência Nacional de Saúde, em 1986, com a proposta do Sistema Unificado de Saúde - SUS e na Constituiçåo de 1988. A SES-SP criou diferentes Comissões de Especialistas e Grupos de Execução (GEPROs). Os GEPROs de Nutrição e de Saúde da Criança estabeleceram por meio de Normas Técnicas, entre outras ações, o sub-programa do leite fortificado com ferro, vitaminas $\mathrm{A}, \mathrm{C} \mathrm{e}$ D (Res. SS 75/91). O leite em pó modificado voltou a ser distribuido nas unidades de saúde (STEFANINI 1994).

Estudos do Grupo de Atenção à Nutrição (GAN) verificaram uma prevalência de anemia de $59,1 \%$ em crianças de 6 a 23 meses, atendidas nas Unidades Básicas de Saúde - UBS. Verificaram, também, que a fortificação do leite com ferro aminoácido quelato (3mg) e vitaminas mostrouse efetiva no combate à anemia. Tal fato levou a SES-SP a publicar a Resoluçăo SS 75, de 12 de março de 1991, aprovando critérios para inscriçăo e acompanhamento de crianças no Programa Integrado de Suplementaçăo Alimentar - PISA, e estabelecendo o enriquecimento do leite (São Paulo 1991).

Nota-se, a partir da década de 80 , uma preocupação governamental crescente com as caréncias nutricionais, em especial a anemia ferropriva, apontada, então, como problema de Saúde Pública.

Em 1993 foi criado o Conselho de Segurança Alimentar - CONSEA, que tinha como uma de suas prioridades o combate à desnutrição maternoinfantil. Para atendé-la foi implantado o Programa de Atendimento aos Desnutridos e às Gestantes - "Leite é Saúde". O programa repassava 
recursos do Ministério da Saúde para os municipios, que distribuiam na rede de Saúde, 1 litro de leite (ou $120 \mathrm{~g}$ de leite em pó) e $24 \mathrm{ml}$ de óleo vegetal para crianças desnutridas, e 0,5 litro de leite para os irmãos dos desnutridos de até 4 anos de idade, e para as gestantes. Esse programa foi fortemente criticado pelos órgăos representativos dos profissionais de saúde e nutrição (STEFANINI 1994).

Considerando a alta prevaléncia de desnutrição energética-protéica e anemia por carência de ferro em crianças na faixa etária compreendida entre 6 e 23 meses de idade atendidas nas UBSs do Estado de São Paulo, e, considerando a importância do efeito da suplementaçăo alimentar nas crianças acometidas por ambos agravos, bem como a necessidade de unificar os programas de Suplementaçăo Alimentar existentes no Estado de Săo Paulo (evitando a duplicaçăo de atividades e otimizando seus resultados), a Resoluçăo SS-489, de 6 de setembro de 1994, da SES-SP, aprovou a Norma Técnica, redefinindo critérios e beneficiários dos Programas de Suplementaçăo Alimentar nas UBSs do Estado de Săo Paulo (SÃO PAULO 1994). Assim, unificaram-se os programas "Leite é Saúde" e "PISA", redefinindo seus beneficiários e critérios. Foram estabelecidas prioridades de atendimento, quantidade de leite a ser distribuida, controle de qualidade do produto, recomendaçס̄es e orientaçס̄es.

Paralelamente, o Estado de Săo Paulo criou, conforme Decreto 37.736, de 27 de outubro de 1993, o Conselho Estadual de Alimentação, junto ao Gabinete do Govemador, composto por 7 secretários de estado e 25 representantes da sociedade civil, convidados pelo Governador (STEFANINI 1994). Ao Conselho cabia, entre outras atribuições, instituir açס̄es emergenciais, no âmbito govemamental e não-govemamental, para suplementaçăo alimentar da populaçăo carente. Nesse sentido, o Decreto supracitado lançou o "Programa São Paulo Vidalimento - Leite", com o objetivo de contribuir para a melhoria das condiçóes nutricionais das crianças carentes do Estado, mediante a distribuição de leite às familias com renda mensal de até 2 salários minimos, que tivessem crianças de 6 meses a 6 anos de idade, a ser coordenado pela Secretaria de Agricultura e 
Abastecimento do Estado de São Paulo (SAA). A operacionalização do Programa se deu por meio de parcerias com entidades da sociedade civil, para a distribuiçăo dos tíquetes às familias cadastradas. O "Programa São Paulo Vidalimento - Leite" foi implantado gradativamente, atendendo a Capital, Regiåo Metropolitana de São Paulo e demais regiōes do Estado, visando obter amostragem de receptividade e funcionamento, para que, à medida que os resultados fossem compativeis com os objetivos, aumentasse o âmbito de sua atuaçăo (SĀO PAULO 1993).

O Programa supracitado foi substituído pelo "Programa Campo/Cidade Leite", criado pelo Decreto 40.036, de 5 de abril de 1995, a ser coordenado pela SAA, por intermédio de sua Coordenadoria de Abastecimento, a qual coube estabelecer as normas regulamentares do Programa, bem como as hipoteses de descredenciamento das entidades parceiras por conduta irregular (SÃO PAULO 1995). Não houve mudanças em relação à operacionalização do programa, o qual seguiu atendendo crianças de 6 meses a 6 anos de idade, de famílias que recebessem até 2 salários mínimos mensais, sendo consentidas 120 familias por entidade, as quais recebiam 15 tiquetes por mês.

O Programa de distribuiçăo de leite no Estado de São Paulo, até outubro de 1995, era executado pela SAA e pela SES-SP. A SAA atendia a Capital e a Regiåo Metropolitana e seu Programa de atendimento ficou suspenso no período de janeiro a março de 1995, por iniciativa dos fornecedores contratados pelo Estado, que passaram a não entregar o produto nos estabelecimentos comerciais. Foi retomado a partir de abril de 1995, quando a divida da gestão anterior, objeto da suspensão, foi saldada. A SES-SP também distribuia o produto na Capital, Região Metropolitana e municípios do interior do Estado, não havendo interrupção alguma dessa atividade (SÃO PAULO 1995).

A partir de julho de 1995, por determinação superior, a SAA passou a ser o órgåo responsável pela compra do leite distribuído pela SES-SP, através das UBSs. Nesse sentido, foram realizadas reuniōes conjuntas entre as Secretarias de Agricultura, Saúde, Fazenda, Casa Civil e Governo, sendo 
que no dia 19 de outubro de 1995 a SAA apresentou um estudo, o qual foi aprovado pelos presentes. Tal estudo mostrou a necessidade de se baixar 0 custo dos Programas de Distribuiçăo de Leite no Estado de Săo Paulo, evitar duplicidade no fornecimento do produto na Capital e Região Metropolitana, bem como de readequar as cotas de leite distribuidas no interior do Estado, visando $o$ atendimento aos municipios que apresentavam maior número de famílias indigentes, de acordo com o Mapa da Fome III, do Instituto de Pesquisa Económica Aplicada - IPEA, do Ministério do Planejamento. A maneira encontrada para se racionalizar a distribuição de leite foi a suspensão do Programa da SES-SP na Capital e Região Metropolitana e o aumento da cota (de 120 para 150 familias) distribuida pelas entidades, no Programa da SAA (SĀO PAULO 1995).

Assim, em outubro de 1995, readequou-se a distribuiçăo de leite em todo o Estado de Såo Paulo, cabendo todo o gerenciamento somente à SAA (SÃO PAULO 1995).

Além disso, foram incluidos no Programa mais 20 municipios, totalizando o atendimento aos 606 municípios do interior do Estado de São Paulo.

Em 7 de março de 1997, por força do Decreto 41.6112, o "Programa Campo/Cidade Leite" foi modificado, estabelecendo-se uma prioridade de atendimento dirigida a crianças de 6 a 23 meses de idade, tendo preferência, ainda, àquelas crianças cujo chefe encontrava-se desempregado ou cuja måe fosse arrimo de família, para a distribuição gratuita de leite. Tal Decreto também instituiu uma Comissăo Estadual, com atribuiçăo de estabelecer metas e critérios para execução do Programa, bem como avaliar periodicamente os resultados obtidos. A Comissão era formada por representantes da SAA, de outras secretarias (Criança, Familia e Bem-Estar Social; Saúde; Emprego e Relaçōes do Trabalho; Governo e Gestão Estratégica) e do Fundo Social de Solidariedade, a qual seria presidida pelo Secretário de Agricultura e Abastecimento, devendo reunir-se de três em três meses (SÃO PAULO 1997). 
Mediante o Decreto 44.569, de 22 de dezembro de 1999, o "Programa Campo/Cidade Leite" foi substituído pelo "Projeto Estadual do Leite VIVALEITE", sendo gerenciado pela SAA, por meio da Coordenadoria de Desenvolvimento dos Agronegócios - CODEAGRO. O mesmo Decreto estabeleceu que o leite distribuído tivesse por caracteristicas ser fluido, pasteurizado, com teor mínimo de gordura de 3\% e enriquecido com ferro e vitaminas $A$ e $D$. As demais diretrizes do Projeto permaneceram as mesmas do "Programa Campo/Cidade Leite" (SÃO PAULO 1999).

O "Projeto Estadual do Leite - VIVALEITE" foi constituído dentro do Programa de Alimentaçăo e Nutrição para Populações Carentes, parte integrante do Plano Plurianual do Agronegócio Paulista 1999-2002, instituido pela Resoluçăo SAA -12, de 16 de junho de 1999 (SĀO PAULO 1999).

Até o ano de 1999, o "Projeto Estadual do Leite - VIVALEITE" resumia-se ao atendimento de crianças, porém o Decreto 45.014, de 28 de junho de 2000 , estendeu esse atendimento a pessoas idosas com renda menor que 2 salários mínimos e idade superior a 60 anos, priorizando as maiores de 65 anos, e, dando preferência, ainda, àquelas portadoras de doença crónica e que faziam uso contínuo de medicamentos (SÃO PAULO 1999).

O "Projeto Estadual do Leite - VIVALEITE" encontra-se, atualmente, ainda regido pelo Decreto supracitado (2000).

A OPS/OMS recomenda que os paises criem projetos de saúde para redução da anemia ferropriva em crianças menores de 2 anos. Essa intervençăo resume-se, basicamente, na fortificaçăo de alimentos de uso massivo pela população alvo. Ainda, essa intervenção deve ser acompanhada de um controle de qualidade do alimento e de um acompanhamento nutricional da populaçăo beneficiada, a fim de se medir o impacto do projeto (FREIRE, 1998).

BEHAR (1991), realizando uma análise critica dos programas de nutrição na América Latina, concluiu que os maiores problemas estavam ligados à escassez de critérios para selecionar os beneficiários, à diversidade de canais para a distribuiçăo de alimentos (serviços de saúde, 
escolas, instituiçס̃es religiosas, etc) e aos critérios de seleção das familias, que nem sempre consideravam o risco nutricional. Somado a essas dificuldades, a avaliaçăo destes programas, em geral, baseavam-se nas quantidades de alimentos distribuídos, mais do que na identificação dos beneficiários e na análise dos possiveis efeitos que poderiam ter ocorrido para prevenir as caréncias nutricionais; era como se o objetivo do programa fosse a distribuiçăo dos alimentos e não o efeito do seu uso.

A literatura tem mostrado, exaustivamente, a importância e as dificuldades de avaliaçăo de programas de intervençåo nutricional. Esta avaliação dos resultados é reconhecidamente um valioso instrumento prático para determinar o alcance dos resultados esperados e avaliar se o programa deve ser reformulado ou reforçado, no sentido de maximizar seus efeitos.

A avaliaçăo destes programas visa quantificar e qualificar as relações existentes entre as atividades de promoçăo nutricional desenvolvidas e seus efeitos no estado nutricional da populaçăo alvo (TADDEI 1983).

É pertinente salientar que, a despeito de sempre estar previsto em todos os Decretos mencionados que regeram o Projeto intitulado hoje VIVALEITE, uma avaliaçăo periódica dos resultados obtidos (a ser realizada em parceria com as Comissōes Estaduais), o mesmo nunca foi avaliado.

\subsection{Projeto Estadual do Leite - VIVALEITE}

O Programa de Distribuiçăo do Leite no Estado de São Paulo teve inicio em outubro de 1.993 sob a denominação de Programa São Paulo VIDALIMENTO. O público alvo a que se destinou o benefício foi o de famílias com renda mensal de até 2 salários mínimos e que possuissem crianças de 6 meses a 6 anos de idade.

Até o segundo semestre de 1994, o Programa atendia apenas à Capital, sendo expandido aos demais municípios da Região Metropolitana de Såo Paulo em agosto do mesmo ano.

A prioridade estabelecida pelo Govemo em relação ao atendimento na Capital e Regiăo Metropolitana prendeu-se ao fato dessas regiões 
aglutinarem o maior índice de indigência da população do Estado, daí a concentração inicial do Programa nessas áreas.

O cadastramento dos beneficiários e a distribuição do benefício ficaram a cargo de entidades filantrópicas da sociedade civil, cadastradas para tal fim na Coordenadoria de Abastecimento (absorvida pela Coordenadoria de Desenvolvimento dos Agronegócios - CODEAGRO, na estrutura atual), órgåo integrante da Secretaria de Agricultura e Abastecimento do Estado de São Paulo.

O sistema de distribuição de leite operava por meio do fornecimento de cartelas com tíquetes entregues mensalmente a cada entidade que, por sua vez, as distribuia as famílias cadastradas, sendo que cada família recebia 30 tiquetes ao més. Esses tíquetes eram trocados por litros de leite tipo $\mathrm{C}$ nos estabelecimentos comerciais mais próximos.

Em abril de 1995, o Programa São Paulo - VIDALIMENTO foi substituído pelo Programa Campo/Cidade - Leite.

No bojo desta reformulação, operou-se uma redistribuiçăo do produto no interior do Estado de Săo Paulo, com base no Mapa da Fome III, elaborado pelo IPEA, em 1993.

Nesse contexto, ocorreram algumas alteraçð̋es nas cotas de leite distribuídas. O número de famílias atendidas, por entidade, aumentou de 120 para 150. Ao mesmo tempo o programa passou a distribuir 15 litros de leite (ao invés de 30) por família beneficiada, na Capital e Região Metropolitana

Em 1996, em virtude de inúmeros problemas verificados no sistema de tíquetes em relaçăo à operacionalizaçăo do Programa (desvios do produto, distorçర̋es detectadas quanto à finalidade do beneficio, falsificação do tíquete, etc.) iniciou-se uma transiçăo para o sistema de entrega de leite direto nas entidades, por meio de um projeto piloto desenvolvido nos municípios de Săo Bernardo do Campo e Mauá que, por um ano e meio, demonstrou a viabilidade do novo sistema e suas vantagens.

Em 1997, foram estabelecidas novas diretrizes para a execução do Programa, ficando estabelecida a prioridade no atendimento às crianças na 
faixa etária de 6 a 23 meses de idade, bem como o atendimento preferencial às famílias cujo chefe encontrava-se desempregado ou cuja mãe fosse arrimo da família.

Em abril de 1.997, o sistema de distribuiçăo de tiquetes, na Capital e municípios do interior do Estado, foi substituido pela entrega de leite fluido, pasteurizado, em embalagem plástica, padronizada, distribuído diretamente as familias inscritas por meio das entidades cadastradas e prefeituras conveniadas. No mesmo ano, a cota de leite distribuida aos municípios do interior do Estado de Săo Paulo passou de 30 para 15 litros mensais de leite, por criança, por més, igualando-se o critério quantitativo com a Capital e Região Metropolitana.

No mesmo ano, o leite passou a ser enriquecido com 6,0mg de ferro (aminoácido quelato), 2000Ul de Vitamina A e 400Ul de Vitamina D, no intuito de combater as duas maiores caréncias nutricionais do Estado, a anemia ferropriva e a hipovitaminose A. Tal decisão foi embasada em discussóes com a equipe técnica da Secretaria de Saúde e a exemplo de estudo realizado no Municipio de Angatuba, por TORRES et al. (1996).

No bojo de uma açăo integrada sob a forma do Programa Estadual de Alimentaçăo e Nutriçăo para as populaçōes carentes e dando curso ao processo de aprimoramento da intervençăo social desenvolvida, foi instituido - Projeto Estadual do Leite - VIVALEITE, em substituição ao Programa Campo/Cidade-Leite.

Em meados de 2.000, operou-se o recadastramento geral das familias atendidas no Projeto, objetivando a correçăo de eventuais distorções e desvios de finalidade no atendimento (duplicidade de inscriçōes, famílias inscritas que năo preenchiam os pré-requisitos para tal, etc.).

Tal recadastramento contou com a participaçăo de servidores da SAA e de outras Secretarias de Estado, de lideranças comunitárias, de voluntários e de servidores e órgăos municipais da Grande São Paulo.

Também em meados do ano 2000, o Projeto ampliou seu atendimento às pessoas idosas de baixa renda com idade superior a 60 anos, priorizando a faixa etária superior a 65 anos, estabelecida a preferência no atendimento 
aos idosos portadores de doença crônica ou que fizessem uso contínuo de medicamento. Este atendimento restringe-se a Capital do Estado de São Paulo.

O Projeto Estadual do Leite - VIVALEITE é, atualmente, gerido pela SAA, por intermédio de sua Coordenadoria de Desenvolvimento dos Agronegócios - CODEAGRO e integra o Programa de Alimentação e Nutrição para Populaçoes Carentes (PAN).

Participam do Projeto VIVALEITE cerca de 4 mil entidades da sociedade civil sem fins lucrativos na Capital e Região Metropolitana, e 606 municípios do interior do Estado, o que se traduz em um atendimento a 720 mil beneficiários, para os quais são distribuídos cerca de 11 milhões de litros de leite mensalmente.

O Projeto VIVALEITE, assim como a maioria dos programas de suplementação alimentar no Brasil, dispunha apenas de dados oficiais de cobertura, como quantidade de leite, distribuição regional, custos, e nada sobre a evoluçăo do estado nutricional da populaçăo, fator de limitação na determinaçăo da efetividade.

Porém, alguns esforços, ainda que discretos, têm sido efetuados nesse sentido.

No ano de 2002, realizou-se um estudo sobre a prevalência de anemia em crianças de 6 a 24 meses, beneficiárias do Projeto VIVALEITE (há pelo menos 6 meses), comparando-as com um grupo controle (que não consumia o leite enriquecido). Os resultados encontrados constataram a necessidade de um aumento do teor de ferro adicionado ao VIVALEITE, que passou de 6 para 7,5 miligramas por litro, possibilitando a denominação de leite enriquecido *.

Ainda como uma açăo relativa à avaliaçăo do Projeto, passou-se a cobrar dos municípios um acompanhamento do estado nutricional das crianças, por meio da complementação do cadastro (para entrada e atualizaçăo das crianças no Projeto) com dados antropométricos e de saúde das crianças, bem como se elaborou um sistema de digitaçăo on line para execuçăo do mesmo. Entretanto, a execuçăo do sistema on line, no que se 
refere ao acompanhamento nutricional, ainda năo se encontra disponivel para utilização pelos municípios, que acabam por remeter essas informaçőes via correio, para a equipe técnica do Projeto. Dessa maneira, nāo é possivvel, até então, aferir-se os resultados pertinentes ao estado nutricional da criança.

O Projeto, atualmente, destina-se ao atendimento de crianças e idosos com baixa renda, por meio da distribuição gratuita de leite fluido, pasteurizado, com teor de gordura minimo de $3 \%$ (três por cento) e enriquecido com $7,5 \mathrm{mg}$ de ferro (aminoácido quelato), $2000 \mathrm{Ul}$ de vitamina $A$ e $400 U 1$ de vitamina $D$.

A quantidade distribuida é de 15 litros de leite por mês, por familia, sendo que na Capital apenas 1 criança em cada família pode ser cadastrada e nos municipios do interior do Estado podem ser cadastradas até 2 crianças por familia.

\subsubsection{Objetivos do VIVALEITE}

O Projeto VIVALEITE destina-se a suprir a carência nutricional da população de baixa renda, melhorando suas condições de vida e promovendo, de forma paralela à intervençăo social direta, uma série de açőes que visam o desenvolvimento comunitário, o resgate da cidadania e a inclusão social de seu público alvo.

$\mathrm{Na}$ Capital e Região Metropolitana o objetivo é efetuar 0 atendimento a população carente com a participação de organizações não governamentais para essas intervençðes sociais, mobilizando a sociedade civil organizada e estabelecendo um canal entre estas e o Poder Público; e nos demais municípios do Interior, desencadear tais ações em parceria com a Municipalidade.

De forma simultånea ao repasse do beneficio, o Projeto tem por objetivo agregar recursos financeiros ao setor leiteiro, ajudando no escoamento da produção, o que permite a criação e manutenção de empregos no campo, causando impacto no fluxo migratório bem como nos 
efeitos negativos dele decorrentes. O Projeto consome aproximadamente $8,2 \%$ da produçăo atual de leite fluido tipo C, do Estado de São Paulo.

\subsubsection{Beneficiários}

O Projeto atende crianças na faixa etária de 6 meses a 6 anos de idade, pertencentes a familias com renda mensal inferior a 2 salários mínimos. Possuem prioridade no atendimento as crianças de 6 a 23 meses, preferencialmente, aquelas cujo chefe encontra-se desempregado e cuja măe é arrimo de familia.

O Projeto, na Capital e Regiåo Metropolitana, atende, ainda, idosos (idade superior a 60 anos) com renda familiar inferior a 2 salários minimos, priorizando-se a faixa etária superior a 65 anos, estabelecida a preferéncia no atendimento aqueles portadores de doença crónica ou que necessitem de uso contínuo de medicamento.

A operacionalizaçăo do Projeto Estadual do leite - VIVALEITE, no modelo de execuçăo atual, encontra-se em texto anexo (ANEXO 1).

\subsection{Ferro e deficiência}

O organismo humano adulto contém de 3 a $5 \mathrm{~g}$ de ferro, aproximadamente $2000 \mathrm{mg}$ como hemoglobina e $8 \mathrm{mg}$ como enzimas. Aproximadamente $90 \%$ do fermo é reutilizado pelo organismo (MAHAN e STUMP 1998).

O ferro exerce um papel no transporte respiratório do oxigênio e dióxido de carbono e é uma parte ativa das enzimas envolvidas no processo de respiraçăo celular (a produçăo de ATP na mitocóndria envolve enzimas que contém ferro) (MAHAN e STUMP 1998).

Assim, o ferro é critico para pessoas de todas as idades (BEARD et al. 1993), já que está envolvido na função e síntese dos neurotransmissores. 


\subsubsection{Absorção e transporte}

O ferro heme é absorvido na mucosa intestinal como um complexo de porfirina intacto, sua absorçăo é de cerca de $25 \%$ comparada com $5 \%$ do ferro não heme. Em casos de deficiência de ferro, este pode ser até $50 \%$ absorvido (MAHAN e STUMP 1998).

Para que o ferro năo heme seja absorvido, ele deve se encontrar no duodeno e jejuno superior, na forma solúvel. Este é ionizado pelo suco gástrico, reduzido à forma ferrosa e quelado com substáncias solubilizantes, como açúcares, ácido ascórbico e aminoácidos que contém enxofre. O ferro năo quelado precipita no duodeno ( $\mathrm{pH} 7$ ), e o ion ferroso é mais bem absorvido nesta faixa de pH (MAHAN e STUMP 1998).

A taxa de absorção de ferro parece estar sob o controle da mucosa intestinal (MAHAN e STUMP 1998). O trato intestinal tem um papel muito importante no mecanismo de reciclagem do ferro corporal, pois a absorção pode ser modificada conforme as necessidades do organismo, ou seja, quando as reservas săo baixas, ocorre aumento significativo da absorção e. contrariamente, quando altas, sua inibiçăo (QUEIROZ e TORRES 2000).

Para que ocorra o aproveitamento de ferro pelo organismo há necessidade de receptores especificos existentes em grandes quantidades nos tecidos que mais necessitam do ferro (medula, figado, placenta). Normalmente, cerca de 70 a $90 \%$ do ferro é captado pela medula óssea, para ser utilizado na produçăo da hemoglobina (QUEIROZ e TORRES 2000). Se uma célula necessita de ferro, ela produz mais moléculas receptoras de transferrina $e$, assim, consegue captar mais do suprimento mineral em circulaçăo (BRUNKEN e SZARFARC 1999).

A ferritina pega o ferro do lúmen intestinal e o traz para a superfície celular, onde se liga ao receptor transferrina, libera o ferro dentro da célula e retorna ao lúmen para pegar mais ferro (MAHAN e STUMP 1998), ou seja, a transferrina distribui o ferro pelo organismo aos locais onde ele é necessário (DE MAYER 1989). 
Dentro da célula da mucosa, o ferro pode se combinar com a apoferritina para formar a ferritina para armazenamento temporário dentro da célula (MAHAN e STUMP 1998).

A taxa na qual o ferro é liberado das células mucosas para a circulação pode ser regulada pela quantidade e saturaçăo da transferrina. $O$ número de receptores de transferrina sobre uma membrana celular pode ser ajustado às necessidades da célula do individuo (MAHAN e STUMP 1998).

A transferrina é normalmente saturada até um terço de sua capacidade total de ligaçăo ao ferro (TIBC). Se o ferro não é necessário, ela permanece saturada e é menos absorvida, sendo descamada no $2^{\circ}$ ou $3^{\circ}$ dia de vida. Se o ferro for necessário, a transferina permanece menos saturada, recebendo mais ferro (MAHAN e STUMP 1998).

Após o processo de digestão, a maior parte do ferro forma um depósito intraluminal, sendo, portanto, sua absorçăo determinada por fatores facilitadores (ácido ascórbico, cames em geral, aminoácidos como lisina, cisteina e histidina, ácidos cítrico e succínico e açúcares, como a frutose) ou inibidores (fitatos, presentes nos cereais; compostos fenólicos como flavonóides, ácidos fenólicos, polifenois e taninos, encontrados nos chás preto e mate, café e certos refrigerantes; sais de cálcio e fósforo, encontrados em fontes protéicas lácteas; fibras e proteína do ovo) (TORRES et al. 1995).

Entre os inibidores da absorçăo estão os polifenóis, fitatos, fosfatos e oxalatos. Os polifenóis săo metabólitos secundários de origem vegetal, ricos em grupos hidroxil fenólicos que formam complexos insolúveis com ferro. Polifenóis de alto peso molecular - os taninos - presentes no chá e no café são os maiores inibidores da absorção de ferro dos alimentos (BOTHWEL et al. 1989). O cálcio, em pequenas quantidades, parece aumentar a absorção de ferro, mas grandes quantidades inibem a absorçăo. Os fosfatos ligados ou năo a proteinas formam complexos insolúveis com ferro e são os principais responsáveis pela baixa biodisponibilidade do ferro dos ovos, leite e derivados. Os fitatos, presentes em muitos cereais (milho, arroz, trigo e leguminosas), inibem a absorçăo do ferro năo-heme da dieta através da 
formaçăo de complexo insolúvel de fitato di e tetra-férrico (LERNER \& IANCU 1988; BOTHWEL et al. 1989).

De acordo com LAYRISSE et al. (1969), NAVES-CABRAL (1990) e SILVA e SILVA (1999), citados por ALMEIDA E NAVES (2002), o feijão apresenta um teor relativamente elevado de ferro (cerca de $7 \mathrm{mg} / 100 \mathrm{~g}$ ), porém o mineral é pouco absorvido pelo organismo (em torno de 3 a $5 \%$ ) devido à presença de fitatos e taninos que inibem a sua absorção. Entretanto, sabe-se que os taninos săo substâncias hidrossolúveis e que o ácido fítico, por sua vez, pode ser desfosforilado durante o processamento de alimentos. Assim, de acordo com CABRAL (1992), citado por ALMEIDA e NAVES (2002), a biodisponibilidade do feijăo pode ser melhorada com técnicas de preparo, como o remolho por algumas horas (desprezando-se a água após) e a retirada da película (peneiraçăo após o cozimento).

Entre os fatores estimuladores da absorçăo de ferro estão as cames e os ácidos orgânicos como o cítrico, málico, tartárico, lático e, principalmente, - ácido ascórbico. O efeito da came como estimulador relaciona-se especificamente à proteína muscular. $O$ mecanismo não foi completamente esclarecido, mas pode estar relacionado à liberação de cisteína e de peptidios com cisteína durante o processo de digestão, formando quelatos peptídio-ferro de fácil absorçăo. O ácido ascórbico converte o ferro férrico em ferroso, tomando-o solúvel no meio alcalino do intestino delgado. Além disso, no ph ácido do estómago, o ácido ascórbico forma um quelato com o cloreto férrico, que permanece estável em pH alcalino (BOTHWEL et al. 1989). De acordo com HALLBERG et al. (1989) e SIEGENBERG et al. (1991), citados por ALMEIDA e NAVES (2002, p.275), em concentraçőes iguais ou superiores a $50 \mathrm{mg}$, quantidade existente em, por exemplo, $100 \mathrm{ml}$ de suco de laranja, o ácido ascórbico pode inibir ou até anular os efeitos negativos dos polifenóis e dos fitatos presentes em uma mesma refeição.

O ferro é mais bem absorvido em ambientes ácidos, por isso, a auséncia de HCL ou a administraçăo de antiácidos diminuem sua absorção. 
Estados fisiológicos, como gestaçăo e crescimento, que exigem maior formaçăo sanguínea, aumentam a absorçăo de ferro, assim como em casos de deficiência do mineral (MAHAN e STUMP 1998).

Apesar de o ferro na forma ferrosa ser mais bem absorvido, nem todos os compostos ferrosos o săo. O pirofosfato ferroso, largamente utilizado para enriquecimento por não conferir cor no alimento, é pobremente absorvido (MAHAN e STUMP 1998).

Para suplementaçăo medicamentosa, devido ao baixo custo e absorçăo rápida, recomenda-se a utilizaçăo de sais ferrosos (sulfato, fumarato, citrato, etc). Entretanto, são comuns alguns efeitos colaterais como náuseas, vơmitos, dor epigástrica, diarréia ou obstipação intestinal, fezes escuras e, em longo prazo, o aparecimento de manchas escuras nos dentes (QUEIROZ e TORRES 2000). Esses efeitos podem ser verificados em 15 a 20\% dos pacientes com tratamento oral com ferro (MASSEY 1992).

\subsubsection{Armazenamento}

Cerca de 200 a $1500 \mathrm{mg}$ de ferro săo armazenados no organismo como ferritina e homossiderina, se a quantidade existente estiver acima das necessidades imediatas do individuo; $30 \%$ está no fígado, $30 \%$ na medula óssea e o resto no baço e músculos. Pode ser mobilizado até $50 \mathrm{mg} / \mathrm{dia}$ do estoque de ferro, sendo $20 \mathrm{mg}$ para sintese de hemoglobina (MAHAN e STUMP 1998; BRUNKEN e SZARFARC 1999).

A medida da ferritina sérica tem sido uma boa ferramenta para avaliaçăo do estado clínico de ferro, já que a ferritina circulante está correlacionada aos estoques de ferro do organismo (MAHAN e STUMP 1998), estejam eles esgotados ou sobrecarregados (BRUNKEN e SZARFARC 1999).

\subsubsection{Excreçåo}

O ferro é perdido pelo organismo apenas através da hemorragia e excretado em quantidades pequenas pelas fezes (a maior parte que não absorvido pela digestão, e o restante da bile e células esfoliadas do epitélio 
gastrointestinal), no suor e na esfoliaçăo normal do cabelo e pele (MAHAN e STUMP 1998; BRUNKEN e SZARFARC 1999).

A perda diária de ferro é de aproximadamente $1 \mathrm{mg}$ no homem adulto e pouco menos na mulher nảo menstruante. Nestas, há uma perda de 0,5mg/dia (MAHAN e STUMP 1998).

\subsubsection{Recomendações}

Considerando-se uma absorção de 10\%, a RDA (Recommended Dietary Allowances) preconiza ingestão diária de $10 \mathrm{mg}$ de ferro elementar para crianças de 6 meses a 3 anos de idade.

Quadro 1 - Recomendaçōes diárias de ferro

\begin{tabular}{|l|c|c|}
\hline \multicolumn{1}{|c|}{ Categoria } & Idade & $\begin{array}{c}\text { Recomendações } \\
\text { diárias de ferro (mg) }\end{array}$ \\
\hline Crianças & $0-6$ meses & 6 \\
& 6 meses a 1 ano & 10 \\
& 1 ano a 10 anos & 10 \\
& $11-18$ anos & 12 \\
\hline Homens & $>19$ anos & 10 \\
\hline Mulheres & $>19$ anos & 10 \\
\hline Grávidas & & 30 \\
\hline Lactantes & & 15 \\
\hline
\end{tabular}

Fonte: RDAINRC (1989)

\subsubsection{Fontes e ingestőes}

Na dieta, podemos encontrar o ferro heme (em alimentos de origem animal) e o ferro năo heme (em alimentos de origem vegetal).

O ferro heme é proveniente de fontes de alimentos de origem animal (hemoglobina, mioglobina e outras heme proteínas). As principais fontes de origem animal são as carnes vermelhas e as visceras, em especial o fígado (MARTINEZ et. al, 1999). Além de ser bem absorvido, devido a sua alta biodisponibilidade, o ferro heme melhora a absorção do pool de ferro não heme (QUEIROZ e TORRES 2000).

O ferro não heme está presente em alimentos de origem vegetal, encontrando-se sob a forma de complexo férrico, que durante a digestão é parcialmente reduzido para a forma ferrosa, de mais fácil absorção, sob a 
açăo do ácido clorídrico, bile e suco pancreático (QUEIROZ e TORRES 1995). Entre as fontes de origem vegetal, as leguminosas têm porcentagem elevada, porém pouco biodisponivel, não sendo consideradas fontes recomendadas de ferro (MARTINEZ et al. 1999).

\subsubsection{Ferro quelato}

Entre as medidas definitivas para o controle e prevenção da anemia ferropriva, a mais premente é encontrar alimentos viáveis de fortificação com ferro, que sejam colocados à disposiçăo da populaçăo, tanto no mercado varejista como em programas de suplementação alimentar com o apoio de legislaçăo específica que controle a qualidade dos mesmos (SZARFARC et al. 1995).

O sucesso da fortificação com ferro depende tanto do composto a ser utilizado como do veículo ao qual vai ser adicionado. A fortificação de leite com ferro é tecnicamente mais dificil em relação a outros nutrientes, principalmente porque as formas mais absorvidas são muito reativas e produzem efeitos indesejáveis quando acrescentadas ao leite (SOGLIA 2001).

Em se tratando do enriquecimento de leite, a composição estrutural do sal ou mineral influi muito na escolha da fonte de ferro a ser utilizada, assim como o custo, solubilidade, reatividade, granulometria, cor, gosto, densidade, cheiro e biodisponibilidade (SOGLIA 2001).

Entretanto, o ferro quelato, além de não comprometer as características organolépticas do leite fluido, tem uma absorção de até $90 \%$ em crianças anêmicas e de $40 \%$ em crianças não anêmicas, sem ser afetado pela dieta (PINEDA 2003).

ASHMEAD (1989), citado por SOGLIA (1996), relata que o ferro aminoácido quelato comporta-se em solução, como um dipeptídio, sendo ionizado somente após sua absorçăo pelo organismo.

SOGLIA (1996), em tese de mestrado sobre o enriquecimento de leite com ferro aminoácido quelato, demonstrou que, mediante dieta adicionada de leite enriquecido com esse composto (com concentraçōes maiores que 
$6,0 \mathrm{mg} / \mathrm{Kg}$ de dieta) foi possivel regenerar ratos anémicos. Ainda, por meio de análise sensorial de leite enriquecido, verificou uma diferença significativa entre o sulfato ferroso e o ferro aminoácido quelato, em relação ao sabor oxidado, sendo atribuido melhor valor ao último, que obteve resultado semelhante ao leite sem a adiçăo de ferro.

RIBEIRO et al. (2000), em estudo sobre suplementaçăo oral com ferro quelato em crianças institucionalizadas de 6 a 36 meses, verificou um aumento médio significante de 1,6g/dL nos niveis de hemoglobina, após 11 meses de consumo. Entre as crianças que iniciaram o estudo com valores inferiores a $9,5 \mathrm{~g} / \mathrm{dL}$, a hemoglobina passou de $8,4 \pm 0,9 \mathrm{~g} / \mathrm{dL}$ para $10,2 \pm$ $1,4 \mathrm{~g} / \mathrm{dL}$, com incremento médio de $1,8 \mathrm{~g} / \mathrm{dL}$.

PINEDA et al (2001), em estudo de suplementação alimentar de crianças de 6 a 36 meses de idade, com ferro quelato, verificou um aumento significativo nos niveis de hemoglobina (de $8,0 \pm 1,49$ para 10,5 $\pm 0,22 \mathrm{~g} / \mathrm{dL}$ ), observando, ainda, uma absorçăo de $90,9 \%$ do ferro quelato por crianças anémicas.

\subsubsection{Deficiência de ferro}

A deficiência de ferro é a mais comum entre as deficiências nutricionais. Os grupos de maior risco são crianças menores de dois anos de idade, adolescentes, gestantes e idosos (MAHAN e STUMP 1998).

A falta de ferro no organismo afeta a imunidade humoral e celular, diminuindo a concentraçăo de linfócitos $T$, a resposta mitogênica e a atividade celular da "natural killer" (NK) (MAHAN e STUMP 1998). Assim, a carência de ferro atinge, em maior ou menor grau, todas as células de um organismo vivo e se traduz por uma enfermidade sistêmica com múltiplos sintomas, conforme os órgãos afetados (TABOADA 1983).

Em síntese, os efeitos da carência de ferro são: a queda da hemoglobina, antes mesmo da ocorrência da anemia; diminuição das ferroenzimas, que afeta todas as células, comprometendo a respiração mitocondrial e o metabolismo energético; diminuição da produção de energia, no sistema muscular, que se traduz pela tendência à inatividade 
física e pela hipotonia muscular, diminuiçăo na síntese de catecolaminas, no sistema nervoso central, traduzindo-se nos sintomas de irritabilidade, fadiga, atenção diminuida, apatia e falta de interesse - todas essas alterações determinam retardo psicopedagógico (TABOADA 1983).

$\mathrm{Na}$ pele e nas mucosas, a queda da hemoglobina reflete-se por estomatite angular, glossite, esofagite e unhas fracas. No sistema digestivo, aparece a anorexia e a diminuiçăo da acidez gástrica, que podem levar à síndrome da má absorçăo. Quanto ao sistema imunológico, tem sido demonstrado que há diminuição na atividade bactericida e na imunidade celular (TOMKINS \& WATSON 1999).

O estágio final da deficiência de ferro é a anemia hipocrômica microcítica (MAHAN e STUMP 1998).

A deficiência de ferro pode ser causada por lesăo, hemorragia e doenças gastrointestinais que comprometem a absorção do ferro, ou, ainda, pela dieta (MAHAN e STUMP 1998).

Entre a populaçăo brasileira, há evidéncias da associação entre prevalência de anemia e deficiência de ferro das dietas, uma vez que nestas a quantidade total e a biodisponibilidade de ferro parecem insuficientes para atender as necessidades de ferro de vários grupos etários (VANNUCHI et al. 1992).

A quantidade de ferro que o feto acumula durante a vida intra-uterina é proporcional ao seu peso. Portanto, quanto menor o peso de nascimento, menor a quantidade orgânica do mineral. Ao nascer, a criança a termo tem cerca de $75 \mathrm{mg}$ de ferro por quilo de peso, dos quais dois terços se encontram sob a forma de hemoglobina (STEKEL 1984; OSKI e NAIMAN 1984). A deficiência de ferro pode manifestar-se mais precocemente em recém-nascidos pré-termo, pois suas reservas neonatais são menores e a velocidade de crescimento é maior quando comparada a dos recémnascidos a termo (DALLMAN 1996).

As reservas fisiológicas de ferro $(0,5 \mathrm{~g} / \mathrm{Kg}$ no recém-nascido a termo) são formadas no último trimestre de gestaçăo. Na prematuridade, pela falta de tempo, e no baixo peso ao nascer, pela pequena reserva, associados ao 
abandono precoce do aleitamento matemo exclusivo, são as causas mais comuns que contribuem para a espoliação de ferro no lactente jovem. $\mathrm{Na}$ primeira infância, o problema agrava-se em decorre̊ncia de erros alimentares, principalmente no periodo de desmame, quando freqüentemente o leite materno é substituído por alimentos pobres em ferro. (QUEIROZ e TORRES 2000).

O recém-nascido a termo apresenta reserva de ferro adequada até os primeiros quatro a seis meses de vida. Após esse período, o ferro alimentar tem importância fundamental na prevençăo da anemia. $O$ leite, principal componente da alimentação infantil, é pobre em ferro, sendo comum a ocorrência de anemia por ocasiåo do desmame (SZARFARC et al. 1995; VITOLO 2003).

Excluindo os prematuros e as crianças de baixo peso ao nascimento, o aleitamento matemo exclusivo assegura ao lactente as reservas orgânicas adequadas de ferro nos primeiros seis meses de vida. A partir desse período, é a qualidade da alimentação complementar que passa a ser responsável por esse processo (VITOLO 2003).

Estudos atuais discutem se o leite matemo é capaz de manter niveis séricos normais de hemoglobina, porém é importante ressaltar que essas pesquisas apresentam limitaçóes metodológicas, e que as posiçőes técnicas estabelecidas por um grupo de experts não devem ser generalizadas (VITOLO 2003).

\subsection{Anemia}

A anemia é uma condiçăo na qual há uma deficiência no tamanho ou número de eritrócitos ou na quantidade de hemoglobina que eles contêm, limitando a troca de oxigênio e dióxido de carbono entre o sangue e as células teciduais. A classificaçăo é baseada no tamanho da célula, podendo ser macrocítica (grande), microcitica (pequena), ou normocítica (normal), e conteúdo de hemoglobina, sendo hipocrômica (cor pálida) ou normocrômica (cor normal). A maioria das anemias é causada pela ausência de nutrientes necessários para a síntese normal de eritrócitos, principalmente ferro, 
vitamina B12 e ácido fólico. Outras podem resultar de hemorragias, anormalidades genéticas, doenças crónicas ou toxicidade de drogas. As anemias por deficiência na ingestão de nutrientes são determinadas anemias nutricionais (MAHAN e STUMP 1998).

A anemia ou o estado decorrente da incapacidade do tecido eritropoiético de manter normal a concentração de hemoglobina é, atualmente, a carência nutricional de maior prevalência no Brasil (MONTEIRO 1988).

A anemia reflete uma deficiéncia grave de ferro e vem precedida da depleçăo das reservas do mineral e de uma eritropoiese ferro-deficiente. Ela é caracterizada pela diminuiçăo da produção de hemoglobina, pelo aumento da protoporfirina eritrocitária livre e pelo aparecimento de microcitose e hipocromia (glóbulos vermelhos menores e menor concentração de hemoglobina, respectivamente) (DALLMAN e YIP 1997).

Foram identificados três estágios na instalação da deficiência de ferro. O primeiro estágio caracteriza-se pela depleçăo de ferro e ocorre quando o aporte do mineral é incapaz de suprir as necessidades orgânicas. Produz, inicialmente, uma reduçăo dos depósitos, que se caracteriza por ferritina sérica abaixo de $12 \mu \mathrm{g} /$, sem alteraçōes funcionais. Se o balanço negativo continua, instala-se a segunda fase, representada pela eritropoiese ferro deficiente, que se caracteriza pela diminuiçăo do ferro sérico, saturação da transferrina abaixo de $16 \%$ e elevaçăo da protoporfirina eritrocitária livre, podendo ocorrer diminuiçăo da capacidade de trabalho. O terceiro estágio caracteriza-se pela anemia por deficiência de ferro, onde a hemoglobina situa-se abaixo dos padrões para a idade e o sexo, pelo aparecimento de microcitose e de hipocromia (QUEIROZ e TORRES 2000).

Os sintomas da anemia incluem fadiga, anorexia e pica (pelo comprometimento do sistema imunológico), maior propensão a infecções (alteração da imunocompetência), e apatia (pela função muscular inadequada), além de diminuiçăo da atençăo, dificuldades de aprendizado e socialização, implicando em alto indice de reprovação e abandono escolar (MAHAN e STUMP 1998). 
De modo geral, a anemia instala-se em conseqüencia de perdas sanguíneas e/ou por deficiência prolongada da ingestão de ferro alimentar, principalmente em periodos de maior demanda, como crianças e adolescentes que apresentam acentuada velocidade de crescimento. Além disso, a gestaçăo e lactaçăo também săo periodos de maior demanda de ferro (QUEIROZ e TORRES 2000).

Vários estudos indicam que a populaçăo mais atingida pela anemia é a de recém nascidos de baixo peso, a de menores de dois anos e de mulheres grávidas (FREIRE 1998). Em menores de dois anos toma-se muito preocupante, pois, nesta fase ocorre um acelerado crescimento do cérebro, desdobramento e fundamentaçăo dos processos mentais e motores e a anemia ai instalada traz conseqüencias desastrosas ao desenvolvimento dessas crianças (SZARFARC et al. 1995).

Entre as principais causas da anemia, podem estar a ingestão de ferro inadequada, a absorçăo inadequada, a necessidade de ferro aumentada para 0 crescimento do volume sanguíneo (infância, adolescência, gravidez e lactaçăo), e excreção aumentada (hemorragias por lesão, doenças parasitárias) (MAHAN e STUMP 1998).

A infestaçăo parasitária por ancilostomideos tem papel importante na etiologia da anemia por causarem perda crónica de sangue (SZARFARC et al. 1995).

Parasitas como o Ancylostoma duodenale ou Necator americanus podem determinar perdas consideráveis de ferro, seja pelo próprio sangue sugado pelo parasita, como pelo sangramento decorrente da lesão na mucosa intestinal causada pelo parasita. Já por competição pelo alimento podem ser apontados o Ascaris lumbricoides e a Giardia lamblia. Deve ser lembrado, entretanto, que de modo geral, a faixa etária de maior incidência desses parasitas é a de maiores de cinco (5) anos de idade (Queiroz e TORRES 2000). Em estudo realizado por LEVY-COSTA (2002), não houve associaçăo significativa entre ocorréncia de parasitoses e concentração de hemoglobina, já que apenas $10,7 \%$ da populaçăo estudada (crianças de 6 a 59 meses) apresentou diagnóstico de parasitose intestinal. 
Assim, a anemia nutricional mais freqüente é o resultado de uma severa deficiência de ferro (SZARFARC et al. 1995).

A anemia nutricional ferropriva é determinada, em última análise, pelo consumo insuriciente de alimentos ou de alimentos fontes de ferro e/ou de baixa biodisponibilidade do ferro ingerido. Desse modo, a absorção de ferro pelo organismo depende năo só das reservas corporais como da forma e quantidade de ferro dos alimentos e da combinaçăo desses em cada refeiçăo (SZARFARC et al. 1995).

A pesquisa "Saúde e Nutriçăo das Crianças de São Paulo" (abril 1984 a junho 1985) verificou o consumo de ferro por crianças de 0 a 60 meses, concluindo que este năo é suficiente para atender às recomendaçōes, conforme a Tabela 2 (MONTEIRO 1988).

A monotonia alimentar no primeiro ano de vida tem sido objeto de estudo de vários autores, demonstrando que o consumo de alimentos fonte de ferro, nessa faixa etária, é menor que o recomendado (TUDISCO et al. 1988, SICHIERI et al. 1988, CALVO e GNAZZO 1990, SOUZA 1994, SPINELLI e SOUZA 2002).

É importante destacar que o uso excessivo de leite de vaca na dieta de crianças, em substituiçăo as refeiçōes principais, pode ser um determinante da anemia, por dois motivos: o leite de vaca em excesso causa microenterorragias, o que, em longo prazo, promove perda de ferro, e a ausência, ou diminuiçăo, da ingestăo das refeiçōes - que seriam as principais responsáveis pelo suprimento diário de ferro (VITOLO 2003; DEVICENZI et al. 1999).

O leite de vaca, apesar de apresentar o mesmo teor de ferro que o leite matemo, tem biodisponibilidade muito baixa $\mathrm{e}$, como se sabe, as mães freqüentemente substituem uma refeiçăo pela mamadeira (QUEIROZ e TORRES 2000)

O risco de anemia é maior entre as crianças em aleitamento artificial (cerca de trés vezes) e entre crianças em aleitamento misto (cerca de duas vezes), do que em crianças que recebem exclusivamente leite materno (MONTEIRO et al. 2000). 
MALE et al. (2001) observaram associação entre a introdução precoce de leite de vaca e baixa concentração de hemoglobina, e correlação positiva entre concentraçăo de hemoglobina e fórmula infantil.

LEVY-COSTA (2002) encontrou associaçăo positiva entre consumo de leite de vaca e baixos niveis de concentração de hemoglobina e maior risco de anemia.

Quadro 2 - Consumo diário de ferro e \% de adequação por crianças. São Paulo. 1984/85.

\begin{tabular}{|l|c|c|}
\hline Faixa etária (meses) & Ferro (mg) & \% Adequação \\
\hline $0 \vdash-6$ & 1,80 & 40,8 \\
\hline $6 \vdash-12$ & 4,72 & 78,9 \\
\hline $12 \vdash-24$ & 6,08 & 88,2 \\
\hline $241-36$ & 6,80 & 94,1 \\
\hline $361-48$ & 7,24 & 90,8 \\
\hline $481-60$ & 6,96 & 79,1 \\
\hline
\end{tabular}

Fonte: MONTEIRO (1988)

\subsubsection{Diagnóstico}

A deficiência de ferro pode ser avaliada por meio da ferritina plasmática, da saturação de transferrina, da hemoglobina, do hematócrito (MAHAN e STUMP 1998), do ferro sérico, da capacidade total de ligação do ferro, da protoporfinina eritrocitária livre e dos receptores de transferrina (PAIVA et al. 2000).

A ferritina sérica avalia as reservas de ferro corporais e apresenta forte correlaçăo com o ferro em depósito nos tecidos (COOK 1979, 1980; WORWOOD 1995), mas não constitui em bom indicador como parâmetro único, pois năo fomece informaçăo a respeito da prevalência de anemia (COOK 1992).

A saturaçăo da transferrina consiste na relaçăo entre o ferro sérico e a capacidade total de ligação do ferro. Esse indicador também apresenta limitações, incluindo a năo especificidade para diagnosticar a deficiência de ferro, modificando-se na presença de infecção (INACG 1985). 
Os indices utilizados no hematócrito são: volume corpuscular médio (VCM), que avalia o tamanho médio dos eritrócitos; amplitude de variação do tamanho dos eritrócitos ou "red distribution width" (RDW), que avalia a variabilidade no tamanho dos eritrócitos; hemoglobina corpuscular média (HCM) e a concentração de hemoglobina corpuscular média ( $\mathrm{CHCM}$ ), que avaliam a concentraçăo de hemoglobina no eritrócito (PAIVA et al. 2000). Esses índices são mais úteis em diagnosticar a carência de ferro após a manifestaçăo da anemia, uma vez que células hipocrómicas e microcíticas aparecem em maior quantidade no sangue após um decréscimo na concentração de hemoglobina (COOK 1990; HASTKA 1994).

O ferro sérico reflete qualquer declínio adicional no ferro corporal quando as reservas de ferro estão exauridas, mas sua concentração pode estar alterada na presença de processos infecciosos (COOK, 1992).

A capacidade total de ligação do ferro avalia o ferro circulante, o qual aumenta na deficiéncia e diminui na inflamação, tomando-se útil na diferenciaçăo das duas situaçð̌es. Porém, pode-se encontrar na faixa de normalidade na presença das duas situaçőes citadas (COOK 1992), além de ser menos sensivel que a ferritina sérica (COOK 1982).

A protoporfirina eritrocitária livre consiste em indicador, já que sua concentraçăo é aumentada no interior das células quando ocorre redução no suprimento de ferro para os eritrócitos (COOK 1979, 1980). Além de não ser utilizada na prática clínica, já que parece não apresentar correlação com outros indicadores, essa medida encontra-se elevada na intoxicação por chumbo (HASTKA 1996).

SKINE et al. (1990) sugeriram a utilização da relação receptores de transferrina/ferritina sérica, uma vez que, na deficiência de ferro a concentração da ferritina sérica encontra-se reduzida e a dos receptores de transferrina aumentada (PAIVA et al. 2000). Além disso, a concentração de receptores de transferrina não é afetada por processos inflamatórios e infecciosos (BEARD 1994; COOK 1992, VAN DEN BROEK et al 1998).

$O$ estágio final da caréncia de ferro está associado a um significativo decréscimo na concentraçăo de hemoglobina, sendo o parâmetro 
universalmente utilizado para definir anemia (PAIVA et al. 2000). Entretanto, a concentração de hemoglobina, como parámetro único para avaliação de anemia ferropriva, é inadequada por três razōes: é afetada apenas tardiamente na doença, năo separa a deficiência de ferro de outras anemias e os valores de indivíduos normais variam amplamente (MAHAN e STUMP 1998). Além disso, pode se encontrar alterada em condiçōes de infecção e inflamação, hemorragia, hemoglobinopatias, desnutrição protéico-calórica, deficiéncia de folato elou vitamina $\mathrm{B} 12$, uso de medicamentos, desidratação, gestaçăo e tabagismo (BEARD 1996; COOK 1992, 1979, 1980).

A avaliaçăo da deficiência de ferro no organismo é mais bem realizada por uma combinaçăo de parâmetros hematológicos e bioquímicos. $\mathrm{Na}$ sua impossibilidade, a alternativa é o uso isolado da dosagem de hemoglobina (PAIVA et al. 2000).

Idealmente, as dosagens de hemoglobina deveriam ser realizadas no sangue venoso, cujos resultados são mais reproduziveis do que com sangue capilar. No entanto, o custo das seringas e agulhas e, principalmente, a resistência da populaçăo à colheita de sangue venoso tornam o capilar a opção viável. O treinamento da técnica adequada e a reciclagem constante são fundamentais para que esse tipo de colheita possa ser utilizado (DALLMAN e SIIMES 1979).

Na maioria dos casos, a presença de hemoglobina baixa associada à história clínica compativel pode determinar o diagnóstico de anemia ferropriva (ALMEIDA 2002).

A determinaçăo da hemoglobina, além de ser o indicador que define a anemia e, portanto, indispensável no diagnóstico da doença, apresenta as vantagens de ser de fácil operacionalização, baixo custo e ser utilizado internacionalmente em estudos comparativos. Além disso, a concentração de hemoglobina é o primeiro indicador a responder a um programa de intervençåo nutricional com ferro em populações anémicas (INACG, 1985).

Assim, a alternativa para paises em desenvolvimento, onde nem sempre é possivel o uso de vários parámetros combinados, é utilizar a concentraçăo de hemoglobina isoladamente. Entretanto, deve-se considerar 
que, nesse caso, o diagnóstico de anemia năo é específico para a deficiência de ferro (YIP e DALLMAN 1997).

A definiçåo operacional de anemia, em termos dos niveis de hemoglobina, foi estabelecido pela OMS, adotando o nivel de $11,0 \mathrm{~g} / \mathrm{dL}$ para crianças menores de seis anos e gestantes. Para crianças de seis a quatorze anos e mulheres adultas năo grávidas, $12 \mathrm{~g} / \mathrm{dL}$, e homens adultos, $13 \mathrm{~g} / \mathrm{dL}$ (QUEIROZ e TORRES 2000).

Quadro 3 - Niveis de hemoglobina indicativos de anemia

\begin{tabular}{|l|c|}
\hline Grupo segundo sexo e idade & Concentração de Hb (g/dL) \\
\hline Crianças de 6 meses a 5 anos & $<11$ \\
\hline Crianças de 6 a 14 anos & $<12$ \\
\hline Homens & $<13$ \\
\hline Mulheres & $<12$ \\
\hline Gestantes & $<11$ \\
\hline
\end{tabular}

Fonte: DEMAYER (1989)

\subsubsection{Prevalência de anemia}

Estudos têm mostrado que a deficiência de ferro é responsável por cerca de $95 \%$ de todas as anemias nutricionais. Trata-se da deficiência nutricional de maior prevaléncia em todo o mundo, principalmente nos países em desenvolvimento devido, principalmente, à baixa ingestão de ferro biodisponivel (DeMAEYER 1989).

Estima-se que dois milhões de pessoas sofram de anemia e entre elas, mais da metade é anêmica. A prevalência em gestantes e menores de dois anos supera o indice de 50\% (FREIRE 1998).

A Conferéncia Internacional de Nutriçăo de 1992 estabeleceu o compromisso de lutar para reduzir as altas prevalências de anemia, que afetam, principalmente as crianças e as gestantes e a Organização Panamericana de Saúde/Organização Mundial de Saúde (OPAS/OMS) adotou como prioritário o compromisso de combater esta deficiência em todo o continente americano (FREIRE 1998). 
A prevalência da anemia ferropriva no Estado de São Paulo tem aumentado, chamando a atenção dos especialistas e interessados em nutriçăo. A anemia na infância, no periodo inferior a dois anos, é o resultado da alimentaçăo, sobretudo, quando este grupo apresenta curta duração de aleitamento matemo, consumo elevado de alimentos lácteos comuns, introdução tardia e em pequenas quantidades de alimentos fontes de ferro ou consumo elevado de substâncias que comprometem a absorção desse mineral (SZARFARC 1990).

Em estudo realizado no Municipio de São Paulo, verificou-se uma prevalência de $66,3 \%$ de anemia em crianças de 6 a 23 meses, e de 34,0\% em crianças de 24 a 59 meses (LEVY-COSTA 2002).

SILVA et al. (2002) encontraram $60,8 \%$ de prevalência de anemia em crianças de 6 a 12 meses, sendo que destes, 55,6\% apresentaram anemia grave.

TORRES e QUEIROZ (1994) verificaram $59,1 \%$ de anemia em crianças de 6 a 23 meses, atendidas nas unidades básicas de saúde do Estado de São Paulo.

\subsubsection{Anemia e carência de vitamina A}

Recentemente tem sido objeto de estudo, a associação entre a carência de vitamina A e a anemia ferropriva, em razão da magnitude e do impacto destas carências especificas em nivel de Saúde Pública. Pesquisas em curso indicam que a vitamina A participa do processo de absorção e transporte do ferro, assim como em sua liberação no figado e no deslocamento do ferro para a medula óssea e sintese de hemoglobina. Desta forma, a deficiência de ferro pode ocasionar prejuizos na absorção de vitamina $A$ e vice-versa. Deste modo, as carências nutricionais apontam para a administraçăo de doses combinadas de vitamina A e ferro. (HADLER et al. 1999).

Atualmente, também se pode estabelecer que o ferro está envolvido nas reaçס̃es de conversăo do beta-caroteno para a forma ativa da vitamina 
$A$, fato esse que explica, em parte, a importante interação entre estes nutrientes (WOLDE-GEBRIELI et al. 1993)

Mediante tal preocupaçăo, o leite do Projeto VIVALEITE combina a fortificaçăo de ambos nutrientes, ferro e vitamina $A$, com o propósito de maximizar os efeitos benéficos da absorçăo destes para o organismo das crianças.

\subsection{Fortificaçåo de alimentos}

A busca de altemativas para o combate à caréncia de ferro que melhor se adapte a cada regiăo do Brasil foi discutida em reunião promovida pela International Life Sciences Institute - ILSI "International Seminar on Enriching Lives Investing in Nutrition", ocorrido em 1997. Mais uma vez, concluiu-se que a fortificaçăo de alimentos, especialmente aqueles utilizados em programas institucionais, deveriam ser nutrificados com nutrientes cuja deficiência ocorre em proporçóes endêmicas, como ferro, e, freqüentemente, a vitamina $A$.

O Encontro Mundial da Cúpula da Criança, ocorrido em Nova York, Estados Unidos, no ano de 1992, estabeleceu, pela primeira vez, em âmbito mundial, o combate à anemia como parte das prioridades de saúde.

Em decorréncia desse encontro, no ano de 1999, firmou-se um compromisso social no Brasil, entre os vários setores da sociedade, com o objetivo de reduzir a prevalência de anemia entre pré-escolares e escolares até o ano de 2003.

A WHO sugere que a deficiencia de ferro seja controlada por programas de educação nutricional combinando açð̄es estratégicas como a suplementaçăo e fortificaçăo de alimentos com ferro, para aumentar o consumo do mineral em populaçðes de risco (WHO 1992).

Vários paises, como Chile e Argentina fazem uso do enriquecimento de alimentos com ferro e vitaminas, principalmente leite fluido (SOGLIA 2001).

SZARFARC et al. (1995) concluiram em artigo sobre a anemia nutricional no Brasil, que a fortificação de alimentos é um dos caminhos mais 
eficazes na prevençăo e controle da deficiéncia de ferro, seja para a populaçåo em geral, seja para grupos específicos.

Para tanto, a prevençăo da anemia ferropriva deve ser estabelecida com base em quatro tipos de abordagens: educaçăo nutricional e melhoria da qualidade da dieta oferecida, incluindo o incentivo ao aleitamento materno, suplementaçăo medicamentosa, fortificação dos alimentos e controle de infecçóes (QUEIROZ e TORRES 2000).

De acordo com SOGLIA (2001), o uso de ferro adicionado ao leite fluido pode preencher os requisitos necessários para ser utilizado em programas estratégicos de prevenção ou tratamento da anemia ferropriva, principalmente quando inseridos em políticas de alimentaçăo (programas sociais de distribuiçăo de leite, etc), que conceda prioridade aos grupos vulneráveis da populaçăo, tanto do ponto de vista biológico, como económico e social.

Vários autores têm tentado com sucesso demonstrar a eficácia da suplementaçăo de ferro por meio da adição do mineral em veiculo alimentar, principalmente o leite.

VIANNA e GONÇALVES (2002) verificaram que uma fórmula láctea fortificada com ferro é mais eficaz que a administração de sulfato ferroso em gotas, na prevençăo da caréncia de ferro e da anemia em crianças nascidas prematuras.

KIM et al. (1996) observaram a relaçăo entre tipo de dieta e anemia, demonstrando que as crianças que foram amamentadas exclusivamente por seis meses tiveram, em média, hemoglobina mais baixa $(10,9 \mathrm{mg} / \mathrm{dl})$ do que as crianças que recebiam fórmula fortificada com ferro $(11,9 \mathrm{mg} / \mathrm{dl})$ e do que as crianças que passaram de aleitamento materno para formula entre o quinto e o sexto mês de vida (11,9 $\mathrm{mg} / \mathrm{dl})$.

TURCONI e TURCONI (1994), em estudo com crianças de 5 a 24 meses, freqüentadoras de creche, verificou, após 6 meses de consumo de leite em pó enriquecido com sulfato ferroso e ácido ascórbico, um decréscimo de $38,8 \%$ para $7,5 \%$, nos índices de anemia. Ainda, no grupo de 
lactentes que ingeriu $400 \mathrm{ml}$ de leite por dia, a prevalência de anemia baixou de $50 \%$ para $0,0 \%$.

\subsubsection{Legislação}

De acordo com a legislação brasileira, a fortificação de alimentos é definida pela Portaria No 31 - Ministério da Saúde/1998, como a adição de um ou mais nutrientes essenciais contidos naturalmente ou não no alimento, com o objetivo de reforçar seu valor nutritivo e/ou prevenir ou corrigir deficiência(s) de em um ou mais nutrientes, na alimentação da população ou de grupos especificos. De acordo com a Portaria $n^{\circ} 27$ (1998), alimentos que contenham vitaminas e/ou minerais que possibilitem o atendimento de $7,5 \%$ e $15 \%$ da ingestão diária recomendada (IDR) em $100 \mathrm{ml}$ (líquidos) do produto pronto para consumo, podem utilizar, respectivamente, as designações fonte e rico em vitamina(s) e/ou mineral (is) (BRASIL 1998 a,b). 


\section{JUSTIFICATIVA DO TRABALHO}

Decidiu-se realizar estudo de prevaléncia de anemia em crianças entre 6 a 36 meses, por compreender o intervalo etário que apresenta a maior susceptibilidade em relaçăo à ocorrência de anemia ferropriva.

Em razăo da importância dessa patologia como problema de Saúde Pública e da inexistência de estudos anteriores que avaliassem o efeito da ingestão do leite do VIVALEITE nos niveis de hemoglobina de crianças beneficiárias, foi proposta uma pesquisa à SAA, tomando-se pioneira na avaliaçăo nutricional do Projeto em questăo. O presente estudo foi realizado por meio de uma parceria entre a SAA e a Faculdade de Saúde Pública da Universidade de Săo Paulo.

Em estudo realizado por CINTRA et al. (2002), verificou-se uma melhora significativa nos niveis de hemoglobina de pré-escolares que receberam $200 \mathrm{~m} /$ dia de leite fortificado com $3,0 \mathrm{mg}$ de ferro quelato por litro, durante o periodo de trinta dias.

TORRES et al. (1996) observaram uma redução significativa da anemia em crianças menores de quatro anos, que receberam leite fluido adicionado de $3,0 \mathrm{mg}$ de ferro quelato, na quantidade de um litro por dia, por um período de seis meses, concluindo a eficácia da fortificação de leite no combate à carência de ferro.

Em se tratando do mesmo tipo de ferro adicionado ao leite do VIVALEITE, sobretudo, em maiores quantidades, esperava-se que o estudo mostre um impacto positivo no estado de ferro das crianças beneficiárias do referido Projeto.

O enriquecimento do leite do VIVALEITE com ferro e vitaminas parte da preocupaçăo govemamental com o fato de que a anemia ferropriva constitui-se em problema de Saúde Püblica e tem por alicerce o reconhecimento da efetividade da suplementaçăo alimentar no combate a essa patologia. Assim, pretendeu-se com este trabalho, aferir se o Projeto em questăo encontrava-se apto a alcançar o seu objetivo. 
Além disso, os conhecimentos gerados a partir deste estudo poderão ser de grande valia para determinar o alcance dos resultados esperados pelo Projeto, assim como planejar açőes futuras de reformulação, no sentido de aprimorar os seus efeitos. 


\section{OBJETIVOS}

\subsection{Objetivo Geral}

Comparar os valores médios de concentraçăo de hemoglobina de crianças de 6 a 36 meses de idade, beneficiárias do Projeto Estadual do Leite - VIVALEITE, antes e depois de receberem leite fortificado com 7,5mg de ferro quelato por litro, durante um período de seis meses.

\subsection{Objetivos Especificos}

- Caracterizar as famílias beneficiadas pelo Projeto VIVALEITE em relação a indicadores sociais e culturais;

- Descrever as caracteristicas das crianças beneficiárias do Projeto VIVALEITE;

- Verificar a associação entre os valores de hemoglobina e as variáveis que podem interferir para a ocorrência de anemia;

- Avaliar o efeito da orientação nutricional fornecida no momento da primeira entrevista;

- Observar as características operacionais do Projeto VIVALEITE e discutir possiveis modificações e implementações, no sentido de maximizar os seus resultados e efeitos na população beneficiada. 


\section{MATERIAL E MÉTODOS}

\subsection{Aspectos Éticos da Pesquisa}

O presente estudo segue os requisitos éticos e normas que regulamentam pesquisas envolvendo seres humanos - Resolução 196/96, do Conselho Nacional de Saúde/Ministério da Saúde, 1996, tendo sido aprovado pelo Comité de Ética da Faculdade de Saúde Pública, da Universidade de Săo Paulo.

O ANEXO 2 representa o termo de consentimento proposto para os pais ou responsáveis, elucidando os aspectos da pesquisa, como esclarecimento sobre a não obrigatoriedade da participação, a inexistência de condicionamento entre a participação na pesquisa e o recebimento do beneficio (leite), a etiologia, fisiologia e conseqüências da patologia, a forma de coleta e a importáncia da pesquisa para a criança e para a comunidade. Além disso, ministrou-se uma breve palestra anteriormente à coleta, na tentativa de melhor elucidar o termo de consentimento, e também pela possibilidade da falta de alfabetização de alguns pais.

O ANEXO 3 representa o termo de encaminhamento, que foi entregue aos pais ou responsáveis, sempre que a criança apresentou diagnóstico de anemia.

\subsection{Delineamento, Local e População do Estudo}

O presente trabalho constituiu-se em estudo de acompanhamento, onde se verificou a concentraçăo dos niveis de hemoglobina antes e após seis meses de consumo de leite do Projeto VIVALEITE.

O estudo foi desenvolvido em municipios do Estado de São Paulo: Itapeva, Piracicaba, Săo José dos Campos, Taubaté e São Paulo (Zonas Leste, Sul e Centro) (Quadro 1). A escolha do local levou em conta o aumento representativo do número de crianças ingressantes no Projeto à época do levantamento. 
A amostra estudada foi constituida por 399 crianças, na faixa etária de seis a trinta e seis meses de idade, ingressantes no Projeto, sendo 280 crianças no interior do Estado de Săo Paulo e 119 crianças no Município de São Paulo.

Quadro 4 - Distribuição da populaçăo amostral, segundo local de estudo. Săo Paulo, 2003-2004.

\begin{tabular}{|l|c|}
\hline \multicolumn{1}{|c|}{ Local de estudo } & Quantidade de crianças \\
\hline Itapeva & 92 \\
\hline Piracicaba & 60 \\
\hline Såo José dos Campos & 83 \\
\hline Taubaté & 45 \\
\hline Săo Paulo Capital & 119 \\
\hline - Centro & 33 \\
\hline - Leste & 41 \\
\hline - Sul & 45 \\
\hline Total & 399 \\
\hline
\end{tabular}

A amostra de crianças estudada no Município de São Paulo encontrou-se dividida por zonas, nas quais foram selecionadas entidades sociais a serem visitadas (trés delas na Zona Sul, três na Zona Leste e uma no Centro). Chama a atençăo que as amostras foram compostas de poucas crianças em cada localidade, o que ocorreu exclusivamente por questőes relacionadas à operacionalizaçăo do Projeto, como o fato do baixo número de ingressantes com as idades fixadas para o estudo, apesar da especificaçåo da faixa etária expressa no Edital do Projeto VIVALEITE.

Para compor a amostra foram selecionados municípios que estavam cadastrando o dobro da quantidade de crianças que costumavam atender (ajustando sua cota, de acordo com a norma estabelecida pela SAA, desde o ano de 1997), e/ou entidades que, no mesmo período, haviam terminado o processo de cadastramento e aguardavam a entrega do leite. 
A escolha da faixa etária para compor a amostra considerou a vulnerabilidade do grupo para a anemia, condição que proporciona maior visibilidade à resposta a partir de alguma intervenção, no caso, ingestão de ferro suplementar, por meio do leite doado.

\subsection{Obtenção dos dados}

A realizaçăo do trabalho de campo, incluindo entrevista com as mães ou responsáveis, exame de anemia e orientação nutricional, deu-se entre o més de março do ano de 2003 e o més de novembro do ano de 2004.

Os responsáveis pelo Projeto VIVALEITE nos municípios e entidades, após serem informados dos objetivos do estudo, convocaram a população cadastrada para as atividades programadas.

As datas agendadas para a coleta de dados foram propositadamente coincidentes com os dias de entrega do leite, no intuito de permitir a observaçăo dessa parte da operacionalização do Projeto.

$\mathrm{Na}$ ocasião foi aplicado um questionário - ANEXO 4, pela própria autora do trabalho e estagiários da SAA devidamente treinados, às mães ou responsáveis pela criança.

Ao agendar a entrevista e o exame com os responsáveis pelo Projeto nos municípios e entidades, ressaltava-se a necessidade da presença da mãe ou responsável pela criança. Na ausência dessas pessoas, o que aconteceu com pequena freqüência $(n=7)$, o aceite dessa condição ocorreu quando a măe ou responsável compareceu no momento da segunda entrevista.

Para a obtenção das informações referentes à operacionalização do Projeto VIVALEITE foram realizadas visitas a CODEAGRO, nas quais foi possivel assistir a palestras sobre o Projeto, bem como entrevistar funcionários de diferentes áreas de atuação. 


\subsection{Variáveis}

Para descrever as características da amostra estudada, foram utilizadas as variáveis independentes:

1 - Variáveis indicativas da condiçăo socioeconômica

- região;

- escolaridade matema e paterna;

- trabalho materno e paterno;

- estado civil materno;

- composiçăo familiar;

- responsável pelos cuidados da criança;

- renda familiar em salários mínimos (referente a 2003: R\$ 240,00);

- participação em outros programas assistenciais.

2 - Variáveis relativas à criança beneficiária do VIVALEITE

- sexo;

- prematuridade;

- peso ao nascer;

- idade de desmame;

- idade no momento do exame;

- uso de ferro medicamentoso;

- presença de doença;

- consumo de alimentos considerados fonte de ferro;

- consumo de leite; formas de preparo, conservação e administração de refeições lácteas;

- distribuiçăo do leite do VIVALEITE na família.

A variável controle utilizada foi

- consumo de leite do VIVALEITE por todos os membros da família.

As variáveis dependentes utilizadas foram

- concentração da hemoglobina da criança (expressa em g/dL);

- prevalência de anemia. 


\subsection{Categorização das variáveis}

1 - Variáveis independentes

1.1. - Variáveis indicativas da condição socioeconómica

- regiấo - a amostra de crianças foi agrupada de acordo com a localidade - Itapeva, Piracicaba, São José dos Campos, Taubaté, e São Paulo (entidades situadas nas Zonas Leste, Sul e Centro).

- escolaridade materna e paterna: categorizadas em:

- analfabeta;

- $1^{\circ}$ grau incompleto;

- $1^{\circ}$ grau completo;

- $2^{\circ}$ grau incompleto;

- $2^{\circ}$ grau completo;

- superior.

- trabalho materno e paterno - determinado pelo questionamento sobre quem sustentava a família, sendo:

- mãe;

- pai;

- mãe e pai;

- outros.

- estado civil materno - determinado mediante relato da mãe, sendo:

- com companheiro;

- sem companheiro.

- renda familiar: em salários mínimos (referente ao ano de 2003 : R\$ 240,00) - a verificação da renda, além de objeto de caracterização da população, teve por objetivo observar se os critérios do Projeto VIVALEITE estavam sendo devidamente cumpridos. 
- composição familiar - para sua determinação, as mães foram indagadas sobre a quantidade de moradores existentes na casa e o número de filhos vivos.

- quem cuida da criança - pessoa que permanece com a criança durante o dia, tratando de sua higiene e alimentação, sendo:

- måe;

- pai;

- avós;

- creche;

- outros.

- consumo de leite do VIVALEITE por todos os membros da família, categorizados por faixa etária - teve por objetivo conhecer o consumo de leite pelos membros da família e, assim, validar a ingestão pela criança beneficiária. Questionava-se à mãe sobre todas as pessoas da família que moravam na mesma casa e consumiam o VIVALEITE. Para averiguação desse consumo, utilizou-se a informação:

- número de pessoas da família que consumiam leite do VIVALEITE, bem como a quantidade ingerida, por dia e por semana.

- participaçăo em outros programas assistenciais - perguntou-se à mãe se a família recebia auxilio de algum programa assistencial, fosse em forma de recursos financeiros ou de alimentos, e solicitava-se, em caso afirmativo, a especificação do programa.

\section{2. - Variáveis relativas à criança beneficiária do VIVALEITE}

- prematuridade - variável dicotômica - prematuro ( $<9$ meses) ou a termo ( $\geq 9$ meses). 
- peso ao nascer - agrupados nas seguintes categorias (PUFFER e SERRANO 1988):

- baixo peso ao nascer: < 2500 gramas;

- peso deficiente ao nascer: 2500 a 2999 gramas;

- peso adequado: $\geq 3000$ gramas.

- idade de desmame: idade em que a criança deixou o aleitamento materno (seja ele exclusivo ou não), categorizada em:

- De 0 a 2 meses;

- De 2 a 4 meses;

- De 4 a 6 meses;

- De 6 a 12 meses;

-12 e mais.

- idade no momento do exame - em meses, determinada pela diferença entre o dia de nascimento e o dia da entrevista, dividido por 30,43 .

- uso de ferro medicamentoso - variável dicotómica - sim ou não: para classificação afirmativa, considerou-se a utilização do suplemento no momento da entrevista.

Procurou-se conhecer se a população fazia uso de sulfato ferroso, tanto para caracterização da amostra, quanto para verificação de possivel associação entre seu consumo e a concentração de hemoglobina. Como năo se questionou sobre a quantidade e o tempo de consumo, não foi possivel verificar a adesão a esse tipo de proposta de suplementação medicamentosa para controle da anemia.

- presença de doença - variável dicotômica - sim ou não: determinada pelo relato da mãe. 
Mediante resposta afirmativa para presença de doença, questionavase o tipo, sendo este um campo para resposta aberta. A especificidade da doença permitiu a avaliação individual da criança, a fim de decidir se a mesma seria mantida na amostra.

- consumo de alimentos considerados fonte de ferro:

- $n^{0}$ de vezes que a criança consumia came durante a semana ( 0 a 7 );

- $n^{\circ}$ de vezes que a criança consumia carne durante o dia $(0,1$ ou 2$)$;

- $n^{\circ}$ de vezes que a criança consumia feijão durante a semana ( 0 a 7$)$;

- $n^{\circ}$ de vezes que a criança consumia feijão durante o dia $(0,1$ ou 2$)$.

O conhecimento sobre a ingestão de dois tipos de alimentos, fonte de ferro heme (carnes) e năo heme (feijão), teve por objetivo verificar os hábitos da criança em relaçăo à ingestão de alimentos fonte de ferro.

- consumo de outros leites (excluindo-se o VIVALEITE); formas de preparo, conservação e administração de refeições lácteas determinada por meio das informaçōes:

- consumo de outro leite - variável dicotômica - sim ou não;

- tipo de leite consumido, entre as opções:

- nenhum,

- "saquinho" (leite fluido pasteurizado),

- "caixinha" (leite UHT, integral),

- materno,

- leite em pó (não industrializado),

- leite cru,

- modificado,

- "soja";

- volume de leite consumido pela criança, por dia e por semana;

Para mensurar o consumo de leite perguntava-se o tipo de leite mais consumido pela criança. Ao relatar mais de um, a mãe era questionada sobre qual deles seria oferecido mais freqüentemente.

O conhecimento sobre o consumo de leite de vaca por crianças fez-se importante, pois existe uma relação estabelecida na literatura entre o 
consumo desse leite e a ocorrência de anemia ferropriva (LEVY-COSTA e MONTEIRO 2004).

A quantidade de leite relatada pela mãe referiu-se a medidas caseiras, como copo e mamadeira. Mediante a resposta, indagava-se o tamanho do utensílio e, dessa maneira, essa quantidade era assinalada no questionário sob a forma de mililitros. Mediante 0 conhecimento da quantidade e freqüência semanal de consumo de outro leite pôde-se verificar durante quantas vezes na semana o VIVALEITE é consumido. Cada criança recebe cerca de 4 litros semanais de VIVALEITE (15 litros por més), sendo que a quantidade relatada nåo póde ultrapassar essa marca.

- hábito de ferver ou não o leite que costuma utilizar em casa variável dicotómica - sim ou nāo, e em caso afirmativo, hábito de descartar ou nåo a nata formada no processo de fervura - variável dicotômica - sim ou não.

O questionamento sobre a fervura ou não do leite do Projeto VIVALEITE e do descarte ou năo da nata formada, além de ter por intuito a caracterizaçăo dos hábitos da população de estudo, objetivou a discussão acerca da possivel perda de ferro por meio dessa nata caracteristica do processo de fervura.

- consumo de leite do VIVALEITE - determinado a partir das seguintes informaçסes:

- quantidade de leite consumida pela criança, por dia e por semana;

- forma com que a criança consome o VIVALEITE:

- puro,

- água,

- café,

- engrossante (amido de milho, creme de arroz, farinha de arroz, outras farinhas, suplemento alimentar),

- achocolatado,

- açúcar,

- frutas,

- outros; 
- quantidade de água utilizada para diluir o VIVALEITE;

- quantidade de café adicionada ao VIVALEITE;

- armazenamento do leite - dentro ou fora da geladeira.

O conhecimento do volume de leite do VIVALEITE consumido teve por objetivos discutir o volume de leite distribuido pelo Projeto, considerando se este é equivalente ao volume de leite habitualmente consumido pela criança, avaliar a diluiçăo intrafamiliar do leite distribuido, e associar esse consumo com os níveis de hemoglobina apresentados pela criança.

Adotou-se como a mistura adicionada ao leite aquela de maior freqüência na dieta da criança, descrita pela mãe. Em casos de consumo de leite com café ou água, a quantidade adicionada foi descontada do volume total de leite.

A variável que buscou a informação sobre o armazenamento do leite do VIVALEITE na geladeira ou em temperatura ambiente teve por objetivo caracterizar a populaçăo, bem como refletir sobre a operacionalização do Projeto. É importante ressaltar que quando as mães relataram não possuir geladeira, mas utilizar a da casa de outra pessoa, o questionamento teve "sim" por resposta.

2 - Variável controle

- volume total de leite do VIVALEITE, consumido por todos os membros da familia - determinada pela soma do consumo individual de cada membro da família, incluindo a criança beneficiária.

O volume total foi trabalhado como variável controle, para verificar se o consumo de leite relatado pela mãe ou responsável, somando-se todas as pessoas da casa, não extrapolava o total de leite distribuido (quinze litros por més), avaliando, assim, se há veracidade do relato. 
3 - Variáveis dependentes

- concentraçåo da hemoglobina da criança: mensurada antes e após seis meses de consumo do leite do VIVALEITE.

- prevalência de anemia - para a classificaçăo das crianças em relaçăo ao estado de anemia, utilizou-se o critério proposto pela OMS (1975): abaixo de $9,5 \mathrm{~g} / \mathrm{dL}$, anemia grave, entre $9,5 \mathrm{~g} / \mathrm{dL}$ e $11,0 \mathrm{~g} / \mathrm{dL}$, anemia moderada.

\subsection{Dosagem da concentraçăo da hemoglobina}

O diagnóstico da anemia foi feito por meio da avaliação da concentraçăo de hemoglobina, utilizando-se o micrométodo colorimétrico de leitura direta, que consiste de punçăo em sangue digital, obtido mediante lanceta e cuveta descartáveis, onde o sangue se instala por meio da capilaridade, e mensuraçåo pelo hemoglobinómetro portátil HemoCue ${ }^{\circledR}$ (VAN SCHENCK et al. 1986; JOHNS \& LEWIS 1989).

O equipamento mencionado fornece a concentração de hemoglobina por fotometria.

Os responsáveis pela realizaçăo do exame foram a autora do trabalho, e estagiários da SAA, devidamente treinados.

O resultado da concentração de hemoglobina era fornecido à instituiçăo e aos pais ou responsáveis pela criança.

É pertinente ressaltar que ao verificar dosagens de hemoglobina inferiores a $7,0 \mathrm{~g} / \mathrm{dL}$, repetia-se o exame para comprovaçăo do resultado.

\subsection{Orientação Nutricional}

Posteriormente à aplicaçăo do questionário às mães ou responsáveis, ou mesmo durante a sua realizaçăo, procedia-se à orientação nutricional, abordando temas gerais relacionados à alimentação saudável, bem como temas especificos, como recomendaçăo de alimentos fonte de ferro para a 
prevenção e controle da anemia ferropriva e cuidados para o aproveitamento adequado do leite do VIVALEITE (ANEXO 4).

Ao final da entrevista e da orientaçăo nutricional, distribuiu-se um folder às mães, abordando informações sobre alimentação saudável, anemia ferropriva e critérios do Projeto VIVALEITE, elaborado por nutricionistas da SAA (ANEXO 5).

\subsection{Digitação dos dados}

Os questionários foram corrigidos e codificados anteriormente à digitação, utilizando o Software Epi Info 6.04 (CDC 1996). Para a revisão do banco de dados, foi utilizado o módulo aplicativo Excel.

\subsection{Análise de dados}

A população estudada foi caracterizada por meio da estatística descritiva, utilizando-se freqüências, médias, desvios-padrão e medianas, sendo apresentados sob a forma de gráficos e tabelas.

Os valores das variáveis obtidas foram cruzados com os índices de hemoglobina, utilizando-se os métodos estatisticos qui-quadrado, com nível de significáncia de $5 \%(p<0,05)$.

Os níveis médios de hemoglobina, antes e depois do ingresso das crianças no Projeto, foram comparados por meio das técnicas estatísticas Análise de Variância (ANOVA) e Teste T Pareado, adotando-se níveis de significáncia de $5 \%(p<0,05)$. 


\section{RESULTADOS E DISCUSSĀO}

Da amostra total, composta por 399 crianças, houve uma perda no seguimento de 175 crianças, seja por que as crianças sairam do Projeto VIVALEITE, seja por que as mães não compareceram à data estabelecida para o segundo exame e entrevista. As perdas, discriminadas pelo local de estudo, encontram-se na tabela 1. Cabe salientar, que, embora a porcentagem de perdas na amostra constitua um valor significante, as características da populaçăo que năo participou da segunda entrevista/análise são deveras semelhantes àquela que participou, dado que ambas fazem parte de um Projeto no qual os critérios para ingresso incluem a faixa etária das crianças e a renda das famílias.

Tabela 1 - Distribuiçăo das perdas na amostra, segundo local de estudo. Săo Paulo, 2003-2004.

\begin{tabular}{lcc}
\hline Local de estudo & $\begin{array}{c}\text { Quantidade de } \\
\text { crianças }\end{array}$ & Perdas (\%) \\
\hline Itapeva & 92 & 40,2 \\
Piracicaba & 60 & 36,7 \\
Săo José dos Campos & 83 & 56,6 \\
Taubaté & 45 & 28,9 \\
São Paulo Capital & 119 & 47,1 \\
- Centro & 33 & 39,4 \\
- Leste & 41 & 43,9 \\
- Sul & 45 & 55,5 \\
\hline Total & 399 & $\mathbf{4 3 , 8}$ \\
\hline
\end{tabular}

Em todas as tabelas apresentadas a seguir, existem perdas na populaçăo total, devido à ausência de resposta. 


\subsection{Caracterização da amostra das familias do VIVALEITE}

Tabela 2 - Distribuiçăo do $n^{\circ}$ e \% de crianças, segundo características da família. Săo Paulo, 2003-2004.

\begin{tabular}{|c|c|c|}
\hline \multirow{2}{*}{ Variáveis } & \multicolumn{2}{|c|}{ Quantidade } \\
\hline & $\mathbf{n}$ & $\%$ \\
\hline \multicolumn{3}{|l|}{ Escolaridade Materna } \\
\hline $\begin{array}{l}<8 \text { anos de estudo } \\
\geq 8 \text { anos de estudos } \\
\text { Total }\end{array}$ & $\begin{array}{l}233 \\
165 \\
398\end{array}$ & $\begin{array}{r}58,5 \\
41,5 \\
100,0\end{array}$ \\
\hline \multicolumn{3}{|l|}{ Escolaridade Patema } \\
\hline $\begin{array}{l}<8 \text { anos de estudo } \\
\geq 8 \text { anos de estudo } \\
\text { Total }\end{array}$ & $\begin{array}{l}219 \\
133 \\
352 \\
\end{array}$ & $\begin{array}{c}62,2 \\
37,8 \\
100,0 \\
\end{array}$ \\
\hline \multicolumn{3}{|c|}{ Responsável pelo sustento da família } \\
\hline $\begin{array}{l}\text { Măe } \\
\text { Pai } \\
\text { Mãe e Pai } \\
\text { Outros } \\
\text { Total }\end{array}$ & $\begin{array}{c}63 \\
240 \\
16 \\
80 \\
399\end{array}$ & $\begin{array}{c}15,8 \\
60,2 \\
4,0 \\
20,1 \\
100,0\end{array}$ \\
\hline \multicolumn{3}{|l|}{ Estado Civil Matemo } \\
\hline $\begin{array}{l}\text { Sem companheiro } \\
\text { Com companheiro } \\
\text { Total }\end{array}$ & $\begin{array}{l}117 \\
282 \\
399 \\
\end{array}$ & $\begin{array}{c}29,3 \\
70,7 \\
100,0 \\
\end{array}$ \\
\hline \multicolumn{3}{|l|}{ Número de moradores } \\
\hline $\begin{array}{l}\text { De } 2 \text { a } 4 \\
\text { De } 5 \text { a } 6 \\
7 \text { ou mais } \\
\text { Total }\end{array}$ & $\begin{array}{c}195 \\
130 \\
74 \\
399 \\
\end{array}$ & $\begin{array}{c}48,9 \\
32,6 \\
18,5 \\
100,00 \\
\end{array}$ \\
\hline \multicolumn{3}{|l|}{ Número de filhos } \\
\hline $\begin{array}{l}\text { De1 a } 2 \\
\text { De } 3 \text { a } 4 \\
5 \text { ou mais } \\
\text { Total }\end{array}$ & $\begin{array}{c}253 \\
107 \\
39 \\
399\end{array}$ & $\begin{array}{c}63,4 \\
26,8 \\
9,8 \\
100,00\end{array}$ \\
\hline \multicolumn{3}{|c|}{ Quem toma conta da criança durante o dia } \\
\hline $\begin{array}{l}\text { Măe } \\
\text { Pai } \\
\text { Avós } \\
\text { Creche } \\
\text { Outros } \\
\text { Total } \\
\end{array}$ & $\begin{array}{c}309 \\
3 \\
30 \\
27 \\
30 \\
399\end{array}$ & $\begin{array}{c}77,4 \\
0,8 \\
7,5 \\
6,8 \\
7,5 \\
100,0 \\
\end{array}$ \\
\hline \multicolumn{3}{|l|}{ Renda } \\
\hline $\begin{array}{l}\text { s } 2 \text { Salários Mínimos } \\
>2 \text { Salários Mínimos } \\
\text { Total }\end{array}$ & $\begin{array}{c}331 \\
51 \\
382 \\
\end{array}$ & $\begin{array}{c}86,6 \\
13,4 \\
100,0 \\
\end{array}$ \\
\hline
\end{tabular}


Tabela 3 - Distribuição do $n^{\circ}$ e \% de crianças, segundo recebimento de programas assistenciais. Såo Paulo, 2003-2004.

\begin{tabular}{lcc}
\hline Programas Assistenciais & $\mathbf{n}$ & $\%$ \\
\hline Năo recebiam & $\mathbf{3 2 5}$ & $\mathbf{8 1 , 7}$ \\
Recebiam & 73 & 18,3 \\
\hline Total & $\mathbf{3 9 8}$ & $\mathbf{1 0 0 , 0}$ \\
\hline
\end{tabular}

É pertinente salientar que, para a caracterização dos beneficiários do VIVALEITE, utilizou-se toda a populaçăo que compareceu no primeiro exame/entrevista. Entretanto, para os resultados comparativos da situação antes e após inscriçåo no Projeto, somente utilizou-se a população que compareceu nos dois momentos (primeiro e segundo exame/entrevista).

A tabela 2 demonstra que a maioria das mães estudadas não completou o ensino de primeiro grau. Da amostra total, 15 mães não eram alfabetizadas. Assim como no caso das mães, a maioria dos pais não completou o ensino de primeiro grau, sendo que 18 pais não eram alfabetizados.

A maioria das familias tinha por provedor o pai, sendo que a mãe não trabalhava fora de casa, fato ratificado pela verificaçăo de que a maior parte das crianças era cuidada pela måe durante todo o dia.

Em relaçăo ao estado civil matemo, a maior parte das mães morava com um companheiro, porém năo tinha sua condição oficializada, declarando-se amasiada.

Pode-se observar que a maioria das familias era composta de 2 a 4 pessoas, sendo que o valor mais observado foi o de 4 pessoas. Como a maior parte das mảes possuia 1 ou 2 filhos, pode-se dizer que as familias eram compostas, na quase totalidade, por pai, mãe e dois filhos.

Do total das familias, $13,4 \%$ encontravam-se fora dos critérios do Projeto VIVALEITE no tocante à renda, já que o Projeto tem por objetivo o atendimento a famílias que recebam até 2 salários mínimos. O valor mínimo observado foi de $\mathrm{R} \$ 287,25$ e valor máximo foi de $\mathrm{R} \$ 1.100,00$ (recebido por uma única família). Ao se categorizar a renda familiar em renda per capita, observou-se que $100 \%$ das familias apresentavam valor inferior a 0,5 salário minimo. 
VISKI (2004), em estudo de caracterização do Projeto VIVALEITE no Municipio de Santo André, verificou que $36,1 \%$ dos beneficiários encontravam-se fora do principal criterio para cadastramento, ou seja, recebiam mais de 2 salários minimos. A diferença encontrada entre o estudo citado e o presente trabalho pode advir do fato de haver diferenças na operacionalizaçăo do Projeto, de acordo com a regiăo onde este é executado. Seria interessante que o estudo de VISKI houvesse observado a renda per capita das familias, já que, apesar do critério do Projeto estar embasado na quantidade de salários minimos, é sabida e reconhecida a arbitrariedade do municipio e das entidades em referência ao cadastramento dos beneficiários. Assim, desde que as familias beneficiárias sejam realmente carentes do ponto de vista financeiro, o Projeto tem sua legitimidade garantida.

Conforme a tabela 3, a maioria das familias năo recebia outro beneficio do govemo, além do VIVALEITE. Entre as que recebiam, os programas mais citados foram "Cesta Básica" $(n=33)$, seguido pelo "Bolsa Escola" (n=16) e "Bolsa Alimentaçăo" (n=15).

\subsection{Caracterização da amostra de crianças do VIVALEITE}

Tabela 4 - Distribuiçăo do $n^{\circ}$ e \% de crianças, segundo suas características. Săo Paulo, 2003-2004.

\begin{tabular}{lcc}
\hline \multirow{2}{*}{ Variáveis } & \multicolumn{2}{c}{ Quantidade } \\
\cline { 2 - 3 } & $\mathbf{n}$ & $\%$ \\
\hline Sexo & 203 & 50,9 \\
\hline Masculino & 196 & 49,1 \\
Feminino & 399 & 100,0 \\
Total & & \\
\hline Prematuridade & 357 & 89,5 \\
\hline A termo & 42 & 10,5 \\
Prematuros & 399 & 100,0 \\
Total & & \\
\hline Peso ao nascer & 39 & 10,3 \\
\hline$<2500 \mathrm{~g}$ & 96 & 25,3 \\
$\geq 2500 \mathrm{~g}$ e $<3000 \mathrm{~g}$ & 244 & 64,4 \\
$\geq 3000 \mathrm{~g}$ & 379 & 100,0 \\
\hline Total & & \\
\hline
\end{tabular}


A distribuiçăo das crianças, em relação a sexo, mostrou-se homogênea, sendo encontrado cerca de metade das crianças pertencentes ao sexo masculino e metade, ao sexo feminino.

$\mathrm{Na}$ primeira e na segunda entrevista foram relatados pela mãe ou responsável pela criança, os problemas de saúde apresentados por ela na ocasiăo. Apenas algumas mães declararam a presença de doença no momento da entrevista (5 crianças foram declaradas doentes na primeira entrevista e 10 na segunda), sendo, na maioria, gripe ou resfriado. Assim, essas crianças foram mantidas no estudo, não sendo analisadas separadamente dquelas que năo apresentaram doença.

A maioria das crianças estudadas apresentou peso adequado ao nascer, porém as porcentagens de peso inadequado $(10,3 \%)$ e peso insuficiente $(25,3 \%)$ mostraram-se relevantes nessa populaçăo. A média de peso ao nascer foi de $3.11 \pm 0.53 \mathrm{Kg}$, e os valores mínimos e máximos observados, $1.50 \mathrm{Kg}$ e $5.00 \mathrm{Kg}$, respectivamente.

LIMA et al. (2004), de forma semelhante, verificaram $9,8 \%$ de crianças nascidas prematuras e $9,4 \%$ com baixo peso, em estudo realizado na Zona da Mata Meridional de Pernambuco, em crianças aos 12 meses de idade. NEUMAN et al. (2000) também encontraram $7,8 \%$ de crianças nascidas com baixo peso, em estudo realizado no Sul do Brasil com crianças menores de 3 anos.

Tabela 5 - Distribuiçăo do $n^{\circ}$ e \% de crianças, segundo consumo de sulfato ferroso. Såo Paulo, 2003-2004.

\begin{tabular}{lcccc}
\hline \multirow{2}{*}{$\begin{array}{c}\text { Consumo de } \\
\text { sulfato ferroso }\end{array}$} & \multicolumn{2}{c}{ Antes } & \multicolumn{2}{c}{ Depois } \\
\cline { 2 - 5 } & $\mathbf{n}$ & $\%$ & $\mathrm{~N}$ & $\%$ \\
\hline Năo consumiam & 126 & 58,0 & 135 & 60,8 \\
Consumiam & 91 & 42,0 & 87 & 39,2 \\
\hline Total & 217 & 100,0 & 222 & 100,0 \\
\hline
\end{tabular}

A tabela 5 mostra que (entre as crianças que participaram da primeira e da segunda entrevista/exame), no momento da primeira entrevista quase metade das crianças estudadas fazia uso de sulfato ferroso. Na ocasião da 
segunda entrevista (6 meses após a inscrição no Projeto VIVALEITE), notase um discreto decréscimo nesse consumo, o qual pode estar relacionado ao aumento da faixa etária das crianças estudadas, ao final do acompanhamento.

Gráfico 1 - Distribuição das crianças, segundo idade de desmame. São Paulo, 2003-2004.

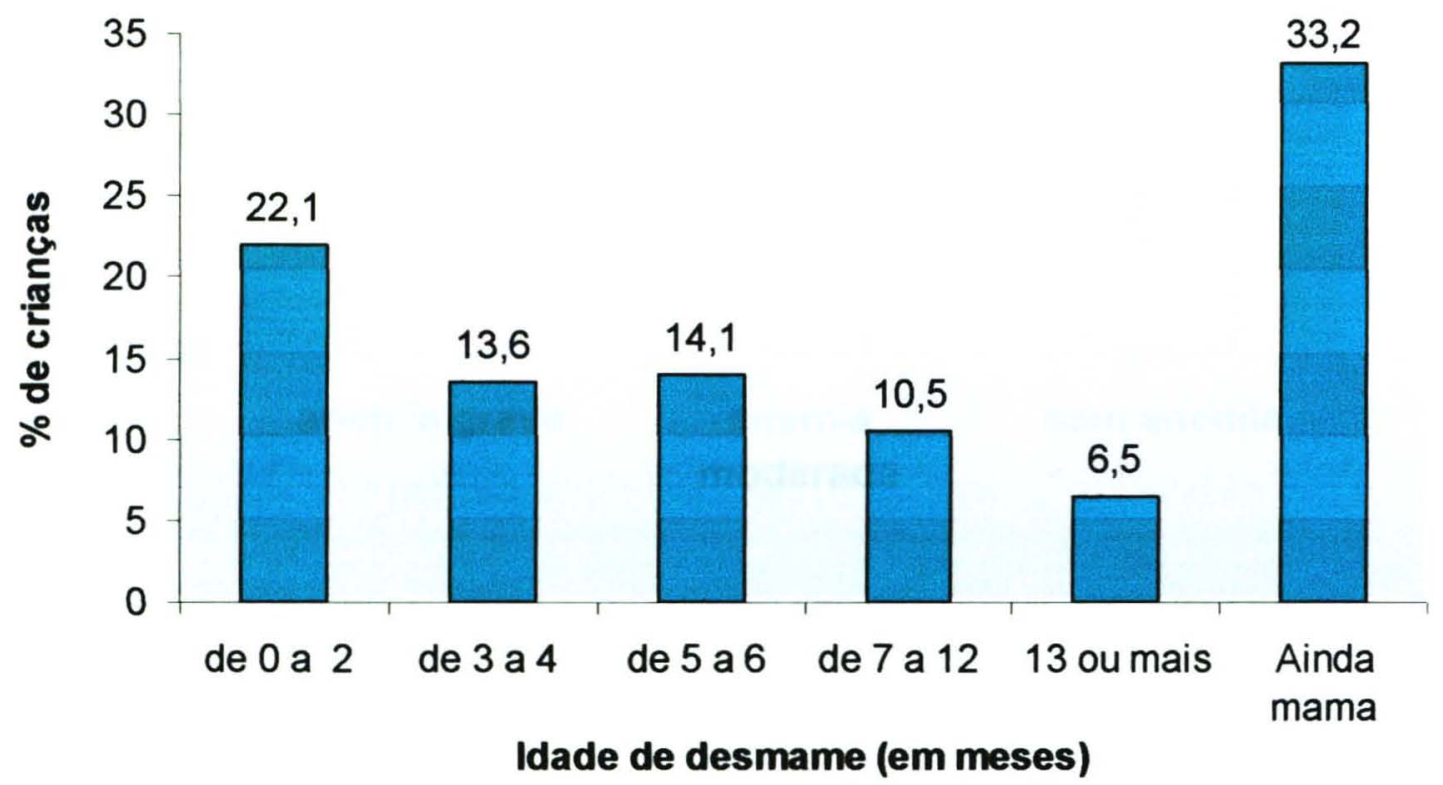

Verificou-se que $33.2 \%$ das crianças ainda se encontravam em aleitamento materno misto, sendo que a idade média dessas crianças foi de $13,8 \pm 5,9$ meses. A proporção de crianças em aleitamento misto é similar à encontrada por SPINELLI (2005), entre crianças menores de 1 ano que freqüentavam serviços públicos de saúde do Brasil. Estes valores permitem supor que as campanhas de incentivo ao aleitamento materno estão surtindo os efeitos esperados entre a população de baixa renda. Em 1984/85, o estudo "Saúde e Nutrição das Crianças de São Paulo" mostrou que a duração média de amamentação era de 111 dias e, que, apenas $53.6 \%$ das crianças estavam sendo aleitadas aos 3 meses de idade. (MONTEIRO e REA 1985, p.55-68). 
Gráfico 2 - Distribuição das crianças, segundo prevalência de anemia no início do acompanhamento. São Paulo, 2003-2004.

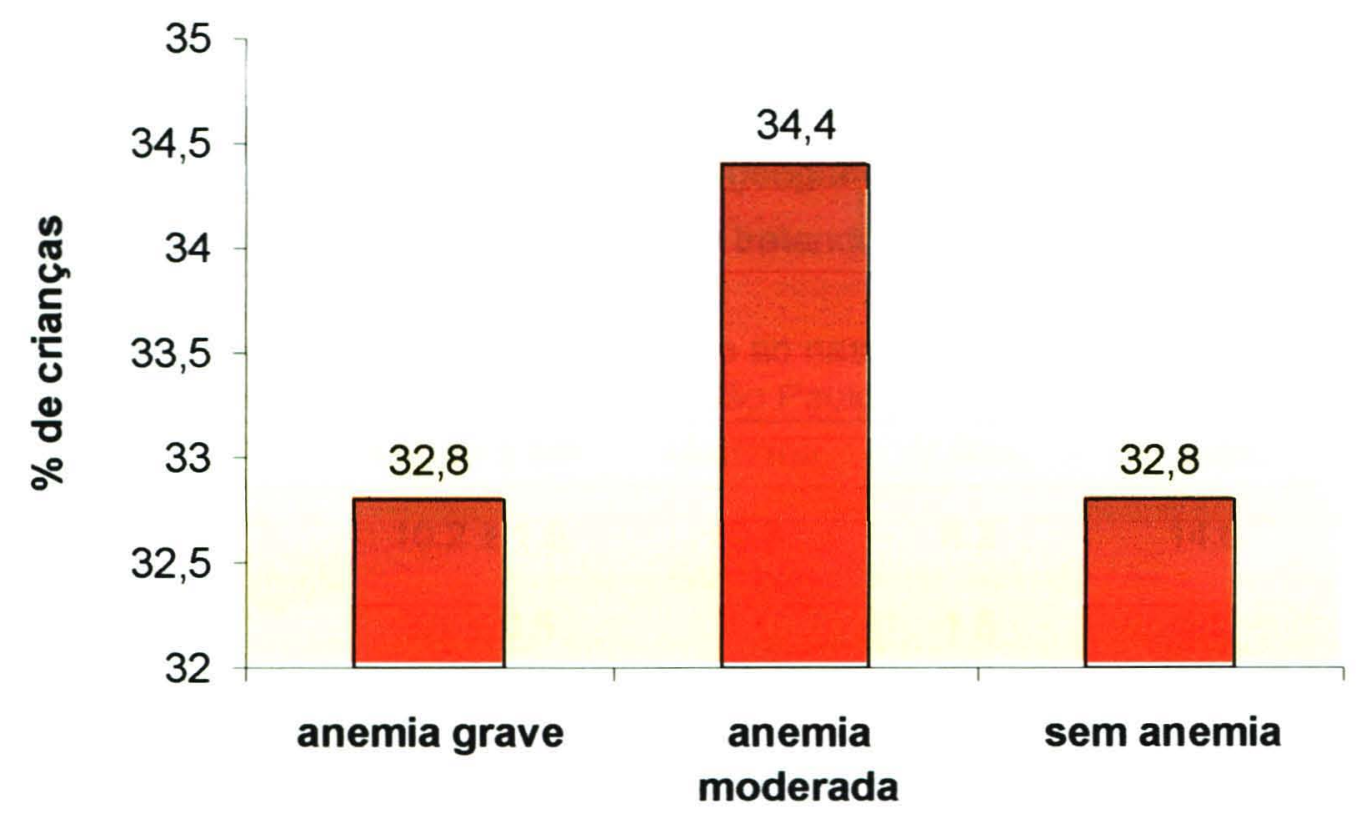

A prevalência de anemia $(<11,0 \mathrm{~g} / \mathrm{dL})$ nas crianças estudadas, no início do acompanhamento, foi de $67,2 \%$, sendo o grupo mais atingido o de crianças de 6 a 12 meses (76,6\%), seguido do grupo de 12 a $24(63,9 \%)$. A média de concentração de hemoglobina observada foi de 10,2 $\pm 1,5 \mathrm{~g} / \mathrm{dL}$.

RIBEIRO et al. (2000) encontraram prevalência de anemia de $65,3 \%$ em crianças de 6 a 12 meses e 69,0\% em crianças de 12 a 24 meses, freqüentadoras de creches no Município de São Paulo. ALMEIDA et al. (2004) encontraram $62,5 \%$ de anemia em crianças de 12 a 72 meses, em estudo realizado no Município de Pontal (São Paulo). TORRES et al. (1995) verificaram uma prevalência de anemia de $70,7 \%$ em crianças de 6 a 23 meses, no Estado de São Paulo. MONTEIRO (2000), em estudo recente no Município de São Paulo, encontrou prevalência de anemia de 46,9\% em crianças menores de 72 meses e de $67,6 \%$ no grupo de 6 a 24 meses. Ainda, LIMA et al. (2004) verificaram, em estudo realizado na Zona da Mata de Pernambuco, uma prevalência de anemia de $73,5 \%$ em crianças aos 12 meses de idade, ASSIS et al. (1997) encontraram 50,0\% em crianças de 12 
a 23 meses, em estudo realizado no semi-árido da Bahia, e NEUMAN et al. (2000), 54\%, em crianças menores de 3 anos, sendo o grupo mais atingido o de 12 a 18 meses, no Sul do Brasil.

Assim, o presente estudo, acordando com os trabalhos supracitados, constata que a anemia ainda se caracteriza como uma patologia de grande abrangência, tanto em referéncia à área geográfica, quanto à quantidade de crianças atingidas, principalmente em se tratando de menores de 2 anos.

Tabela 6 - Médias de hemoglobina, peso ao nascer, desmame e consumo de leite no início do acompanhamento. Săo Paulo, 2003-2004.

\begin{tabular}{ccccc}
\hline Variável & Media \pm DP & Mediana & V.Mín. & V.máx. \\
\hline $\begin{array}{c}\text { Hemoglobina } \\
\text { (g/dl) }\end{array}$ & $10.2 \pm 1.5$ & 10.3 & 6.2 & 14.6 \\
$\begin{array}{c}\text { Peso ao nascer } \\
\text { (gramas) }\end{array}$ & $3.1 \pm 0.5$ & 3.1 & 1.5 & 4.5 \\
$\begin{array}{c}\text { Desmame } \\
\text { (dias) }\end{array}$ & $149 \pm 132$ & 120 & 0 & 730 \\
$\begin{array}{c}\text { Consumo diário } \\
\text { de leite (ml) }\end{array}$ & $699 \pm 440$ & 720 & 0,0 & 2.000 \\
\hline
\end{tabular}

Tabela 7 - Distribuiçăo das crianças, segundo média de consumo diário de leite por idade, relatado pela mãe ou responsável, no início do acompanhamento. Săo Paulo, 2003-2004.

\begin{tabular}{ccccc}
\hline $\begin{array}{c}\text { Idade } \\
\text { (meses) }\end{array}$ & $\mathbf{n}$ & $\begin{array}{c}\text { Média de consumo } \\
\text { (em ml) }\end{array}$ & $\begin{array}{c}\text { Mediana de } \\
\text { consumo (em ml) }\end{array}$ & Desvio-Padrão \\
\hline $6 \vdash 12$ & 157 & 743 & 960 & 475 \\
$12 \vdash 24$ & 200 & 655 & 720 & 428 \\
24 e mais & 38 & 746 & 720 & 325 \\
\hline
\end{tabular}

Em estudo sobre anemia e consumo de leite da vaca, realizado por LEVY-COSTA e MONTEIRO (2004), foram encontradas médias de consumo de leite de vaca, por idade, conforme o Quadro 5. 
Quadro 5 - Média de consumo diário de leite por crianças. São Paulo. 2002

\begin{tabular}{|l|c|}
\hline Idade (em meses) & $\begin{array}{c}\text { Média de consumo diário de leite de vaca } \\
\text { (em ml) }\end{array}$ \\
\hline $6 \vdash 12$ & 600,7 \\
\hline $12 \vdash 24$ & 573,6 \\
\hline $24 \vdash 36$ & 487,7 \\
\hline $36 \vdash 48$ & 475,2 \\
\hline $48 \vdash-60$ & 315,3 \\
\hline
\end{tabular}

O presente trabalho encontrou médias diárias de consumo de leite de vaca maiores que o estudo supracitado. LEVY-COSTA e MONTEIRO (2004) concluiram, ainda, que, enquanto a participação de leite de vaca na dieta diminuiu, a densidade total de ferro aumentou. $O$ consumo elevado de leite de vaca por crianças verificado neste trabalho, no inicio do acompanhamento, pode ser uma das causas da alta prevaléncia de anemia $(67,2 \%)$ encontrada nas mesmas, visto que o consumo de grande quantidade de leite pressupōe a substituiçăo de refeições por este alimento. QUEIROZ e TORRES (2000) relataram que as mães freqüentemente substituem uma refeiçăo pela mamadeira.

Tabela 8 - Distribuiçăo do $n^{\circ}$ e \% de crianças, segundo consumo de leite no início do acompanhamento. Săo Paulo, 2003-2004.

\begin{tabular}{lcc}
\hline \multirow{2}{*}{ Tipo de leite consumido } & \multicolumn{2}{c}{ Quantidade } \\
\cline { 2 - 3 } & $\mathbf{n}$ & $\%$ \\
\hline Leite pasteurizado & 65 & 29,0 \\
Leite UHT & 72 & 32,1 \\
Leite materno & 35 & 15,6 \\
Leite em po & 27 & 12,0 \\
Leite cru & 11 & 5,0 \\
Leite modificado & 1 & 0,4 \\
"Soja" & 1 & 0,4 \\
Outros & 12 & 5,5 \\
\hline Total & $\mathbf{2 2 4}$ & $\mathbf{1 0 0 , 0}$ \\
\hline
\end{tabular}


Tabela 9 - Distribuição do $n^{\circ}$ e \% de crianças, segundo consumo de leite (VIVALEITE ou outro) ao final do acompanhamento. São Paulo, 2003-2004.

\begin{tabular}{lcc}
\hline Consumo de leite & \multicolumn{2}{c}{ Quantidade } \\
\cline { 2 - 3 } & $\mathbf{n}$ & $\%$ \\
\hline Só consumiam VIVALEITE & 21 & 9,4 \\
Consumiam VIVALEITE e outros & 203 & 90,6 \\
\hline Total & $\mathbf{2 2 4}$ & $\mathbf{1 0 0 , 0}$ \\
\hline
\end{tabular}

Tabela 10 - Distribuiçăo do $n^{\circ}$ e \% de crianças, segundo frequência de consumo de leite (não VIVALEITE) ao final do acompanhamento. São Paulo, 2003-2004.

\begin{tabular}{lcc}
\hline Freqüéncia semanal de & \multicolumn{2}{c}{ Quantidade } \\
\cline { 2 - 3 } consumo de outro leite & $\mathbf{n}$ & $\%$ \\
\hline De 0 a 1 vezes & 24 & 10,7 \\
De 2 a 3 vezes & 98 & 43,8 \\
De 4 a 5 vezes & 69 & 30,8 \\
De 6 a 7 vezes & 33 & 14,7 \\
\hline Total & $\mathbf{2 2 4}$ & $\mathbf{1 0 0 , 0}$ \\
\hline
\end{tabular}

No inicio do acompanhamento (apenas para as crianças que compareceram na primeira e na segunda entrevista), a maioria das crianças consumia leite UHT, o qual foi referido pelas mães como "leite de caixinha", seguido do leite pasteurizado, referido como "leite de saquinho". É importante observar que 11 crianças consumiam leite cru. $O$ consumo deste leite somente foi verificado nos municipios do interior do Estado de São Paulo, sendo relatado pelas mães como o leite trazido pela pessoa que trabalha na fazenda, geralmente em garrafas "pet". Cabe salientar que, apesar da tabela 8 tratar do consumo de leite no início do acompanhamento (antes do recebimento do VIVALEITE), algumas crianças $(n=12)$ somente ingeriam leite do VIVALEITE, seja pelo fato de que já se encontravam como beneficiárias do Projeto, seja por que algum parente ou vizinho beneficiário dividia o alimento com as mesmas, ou, ainda, por se acharem na lista de espera, e receberem as "sobras" de leite. Essas crianças foram incluidas na opçăo "outros", quanto ao tipo de leite consumido, na referida tabela. Apesar de categorizados por tipo de leite, vale salientar que, à exceção das crianças que consumiam somente leite materno $(n=35)$ e daquela que ingeria produto à base de soja $(n=1)$, a grande maioria consumia leite de vaca ( $84 \%)$. 
Ao final do acompanhamento, conforme observado na tabela 9, já era prevista a complementaçăo do leite do VIVALEITE, já que a quantidade média de leite consumida pelas crianças no inicio do acompanhamento era maior que o volume de leite oferecido pelo Projeto.

Apenas poucas crianças $(9,4 \%)$, do total da amostra, faziam uso do VIVALEITE de forma exclusiva. O restante, apesar de consumir leite do VIVALEITE, fazia uso de outro tipo de leite. Dentre os tipos de leite mais consumidos pelas crianças encontrou-se, à exemplo do observado na primeira entrevista, o leite "de caixinha" (UHT), seguido do leite "de saquinho" (pasteurizado). Observando-se o número de vezes na semana que a criança consumia outro tipo de leite, de acordo com a tabela 10, podese observar, novamente, que o leite do VIVALEITE não é suficiente para garantir o consumo da criança durante toda a semana, sendo necessária a aquisiçăo de outro leite pela familia. Vale lembrar que, em relaçăo à criança que consumia produto à base de soja no primeiro momento, esta passou a consumir leite do VIVALEITE, complementado pelo leite de "caixinha", demonstrando năo possuir intolerância ou alergia ao leite de vaca.

No que diz respeito ao tratamento térmico do leite no início do acompanhamento, póde-se notar que a maioria das mảes ou responsáveis $(69,8 \%)$ tinha por hábito ferver o leite. Dentre as pessoas que ferviam o leite, grande parte $(57,4 \%)$ descartava a nata formada, năo fazendo uso desta na alimentaçăo da criança.

Quanto ao armazenamento do leite no início do acompanhamento, a maioria dos entrevistados relatou possuir geladeira em casa, conservando-o sob refrigeraçăo. 
Tabela 11 - Distribuiçăo do $n^{\circ}$ e \% de crianças, segundo consumo de leite do VIVALEITE pelo beneficiánio, relatado pela mãe ou responsável, ao final do acompanhamento. Såo Paulo, 2003-2004.

\begin{tabular}{|c|c|c|}
\hline \multirow{2}{*}{ Variáveis } & \multicolumn{2}{|c|}{ Quantidade } \\
\hline & $\mathbf{n}$ & $\%$ \\
\hline \multicolumn{3}{|c|}{$\%$ de consumo do VIVALEITE } \\
\hline $\begin{array}{l}0-125 \\
25-150 \\
50-175 \\
75-1100 \\
\text { Total } \\
\end{array}$ & $\begin{array}{c}8 \\
47 \\
54 \\
115 \\
224 \\
\end{array}$ & $\begin{array}{c}3,6 \\
21,0 \\
24,1 \\
51,3 \\
100,0 \\
\end{array}$ \\
\hline \multicolumn{3}{|c|}{ Consumo referido de VIVALEITE (em ml) } \\
\hline $\begin{array}{l}150-1480 \\
480-720 \\
720-1960 \\
960 \text { e mais } \\
\text { Total }\end{array}$ & $\begin{array}{c}41 \\
82 \\
80 \\
21 \\
224\end{array}$ & $\begin{array}{c}18,3 \\
36,6 \\
35,7 \\
9,4 \\
100,0\end{array}$ \\
\hline \multicolumn{3}{|c|}{ Forma de consumo do VIVALEITE } \\
\hline $\begin{array}{l}\text { Puro } \\
\text { Com Água } \\
\text { Com Café } \\
\text { Com Engrossante } \\
\text { Com Achocolatado } \\
\text { Com Açúcar } \\
\text { Com Frutas } \\
\text { Outros } \\
\text { Total }\end{array}$ & $\begin{array}{c}62 \\
1 \\
22 \\
78 \\
37 \\
19 \\
2 \\
3 \\
224\end{array}$ & $\begin{array}{c}27,7 \\
0,4 \\
9,8 \\
34,9 \\
16,5 \\
8,5 \\
0,9 \\
1,3 \\
100,0\end{array}$ \\
\hline \multicolumn{3}{|c|}{ Freqüência semanal de consumo de VIVALEITE } \\
\hline $\begin{array}{l}\text { De } 0 \text { a } 1 \text { vezes } \\
\text { De } 2 \text { a } 3 \text { vezes } \\
\text { De } 4 \text { a } 5 \text { vezes } \\
\text { De } 6 \text { a } 7 \text { vezes } \\
\text { Total }\end{array}$ & $\begin{array}{c}6 \\
79 \\
117 \\
22 \\
224 \\
\end{array}$ & $\begin{array}{c}2,7 \\
35,3 \\
52,2 \\
9,8 \\
100,0\end{array}$ \\
\hline
\end{tabular}

Tabela 12 - Consumo de leite do VIVALEITE por crianças beneficiárias (ao final do acompanhamento), segundo relato da mãe ou responsável. São Paulo, 2003-2004.

\begin{tabular}{ccccc}
\hline Variável & Média (DP) & Mediana & V.Mín. & V.Máx. \\
\hline $\begin{array}{c}\text { Consumo diário de } \\
\text { leite do VIVALEITE } \\
(\text { em ml) }\end{array}$ & $800(251)$ & 720 & 150 & 1920 \\
\hline
\end{tabular}

De acordo com a tabela 11, pode-se observar que a maioria das crianças compartilhava a quantidade de leite do VIVALEITE recebida com outras pessoas da casa. O estudo verificou que grande parte das crianças 
consumia de 75 a $100 \%$ do total de leite recebido, porém nenhuma criança fazia uso de $100 \%$ do leite recebido.

O consumo médio diário de leite do VIVALEITE pela criança, referido pela mãe ou responsável, foi de $800 \mathrm{ml}$, ressaltando que o consumo deste se fazia de 4 a 5 vezes na semana, totalizando cerca de 3.200 a $4.000 \mathrm{ml}$ de leite por semana. Este fato demonstra que as crianças beneficiárias ingeriam a maior quantidade do leite recebido e que, na maioria das vezes, fazia-se necessário a aquisição de outro leite pela familia, em complementação ao distribuido pelo Projeto, já que a quantidade de leite distribuída não é suficiente para o consumo da criança durante todos os dias da semana.

Salienta-se assim, que, nos casos em que a mãe relatava um consumo de leite maior que $0,5 \mathrm{~L}$, ocorria, na prática, uma ingestão da quantidade total (ou quase) de leite do VIVALEITE no dia do recebimento do mesmo, e uma ausência de consumo deste nos dias em que não havia entrega. Assim, o consumo diário expresso na tabela 12 refere-se, na verdade, ao consumo de VIVALEITE nos dias de entrega. Já que em cada entrega de leite recebe-se de 1 a $2 L$ de leite, toma-se possivel a ocorrência de consumos maiores de $0,5 \mathrm{~L}$, seguidos de ausência de ingestão.

Quanto ao relato da mǻe ou responsável, notou-se que, à priori, a resposta sobre o consumo referia-se, exclusivamente, ao leite do VIVALEITE. Entretanto, ao serem questionadas quanto à "duração" do leite (número de dias da semana nos quais o VIVALEITE é suficiente para o consumo diário), a resposta era modificada. Assim, há uma tendência à demasia na resposta das mães ou responsáveis, viés que pode vir a ser minimizado por conta da insistência do entrevistador.

Em relação à forma de consumo, verificou-se que a maioria das crianças fazia uso do leite adicionado de algum tipo de engrossante, como amido de milho, farinhas, creme de arroz e suplementos. É pertinente observar que o consumo de frutas (batidas com leite) por essa população é extremamente baixo.

No momento da segunda entrevista, póde-se observar que a maioria das mães não fervia o leite do VIVALEITE e quando o fazia, não descartava 
a nata, seguindo as orientaçőes dadas na primeira entrevista. O leite, na maioria das vezes, era armazenado em geladeira, à exemplo do observado anteriormente.

Tabela 13 - Distribuiçăo do $n^{\circ}$ e \% de crianças, segundo consumo semanal de alimentos fonte de ferro. Såo Paulo, 2003-2004.

\begin{tabular}{|c|c|c|c|c|c|c|c|c|c|c|c|}
\hline \multirow{2}{*}{ Alimento } & \multicolumn{2}{|c|}{0} & \multicolumn{2}{|c|}{$1-2$} & \multicolumn{2}{|c|}{$3-4$} & \multicolumn{2}{|c|}{$5-6$} & \multicolumn{2}{|c|}{7} & \multirow{2}{*}{ Total } \\
\hline & $n$ & $\%$ & $n$ & $\%$ & $n$ & $\%$ & $n$ & $\%$ & $n$ & $\%$ & \\
\hline Came & 49 & 12,3 & 115 & 28,9 & 87 & 21,9 & 40 & 10,1 & 106 & 26,7 & 397 \\
\hline Feijąo & 25 & 6,3 & 10 & 2,5 & 18 & 4,5 & 70 & 17,6 & 274 & 69,0 & 397 \\
\hline
\end{tabular}

Nota-se, na tabela 13, que o consumo de came foi semelhante entre um ou dois dias na semana e em todos os dias da semana. Tal comportamento parece ser mais devido ao paladar da criança do que à renda familiar, visto que esta se encontrou homogênea na população de estudo. Comumente, mediante questionamento sobre a alimentaçăo da criança, as măes respondiam que a mesma năo gostava de carne.

$O$ consumo de feijăo mostrou-se bem mais freqũente que o consumo de came. Observou-se que $o$ alimento apresentou uma ótima aceitabilidade por parte da criança, fazendo parte de sua dieta habitual.

Quanto ao consumo diário desses alimentos nas refeiçőes, a came, quando relatado o seu consumo, esteve presente com mais freqüência em apenas uma delas, ao contrário do feijāo, que quando consumido, teve sua ingestăo presente, com mais constância, tanto no almoço quanto no jantar.

Tabela 14 - Distribuiçăo do $n^{\circ}$ e \% de crianças, segundo consumo de VIVALEITE por membros da familia (excluindo-se a criança beneficiária) diluiçăo intrafamiliar. Săo Paulo, 2003-2004.

\begin{tabular}{lcc}
\hline \% de consumo de & \multicolumn{2}{c}{ Quantidade } \\
\cline { 2 - 3 } VIVALEITE & $\mathbf{n}$ & $\%$ \\
\hline De 0 a 5 & 141 & 62,9 \\
De 6 a 15 & 49 & 21,9 \\
De 16 a 24 & 34 & 15,2 \\
\hline Total & $\mathbf{2 2 4}$ & $\mathbf{1 0 0 , 0}$ \\
\hline
\end{tabular}


A maioria das mães (ou responsáveis), quando perguntadas no momento da segunda entrevista (há pelo menos 6 meses de consumo de leite do VIVALEITE) sobre a quantidade de pessoas na casa que consumiam - leite distribuido pelo Projeto, relatou não haver outros moradores, independente da faixa etária, que o consumiam, explanando que este leite era só para a criança beneficiária do Projeto. Entretanto, ao se questionar sobre cada membro da família e sobre o consumo deste em relação ao VIVALEITE, notou-se que, em alguns casos, a informação anterior foi contraditória. Assim, a insisténcia do entrevistador, novamente evitou a possibilidade de um viés na pesquisa.

Considerando como diluiçăo intrafamiliar a situação em que o leite é dividido entre a criança beneficiária e pelo menos uma outra pessoa da familia, observou-se que esse comportamento está presente em 97 famílias, ou seja, em $43,3 \%$ dos casos, apesar do consumo, por essa outra pessoa, ser baixo. Nota-se que as outras pessoas da família consumiam, no máximo, $24 \%$ do total de leite do VIVALEITE, revelando que a criança beneficiária consumia a maior parte do leite distribuido pelo Projeto.

Nota-se, ainda, que a maior diluiçăo intrafamiliar é constatada quando existem crianças menores de sete anos na casa. Entre os 97 casos de diluiçăo intrafamiliar encontrados, 80 (89\%) ocorria em familias que tinham crianças menores de sete anos.

TORRES (1996) et al., em estudo sobre distribuição de leite fluido fortificado com ferro quelato para crianças menores de quatro anos, constataram diluiçăo intrafamiliar em $\mathbf{4 4 , 4 \%}$ dos casos. Verificaram, também, uma melhora mais significativa dos niveis de hemoglobina em crianças cujas familias não consumiam o leite. No grupo em que houve diluição intrafamiliar, a prevalência de anemia passou de $58,5 \%$ para $28,3 \%$, enquanto no grupo em que năo foi verificado esse tipo de comportamento, a prevalência de anemia passou de $65,1 \%$ para $24,8 \%$. Ainda, a ocorrência de anemia decresceu de $62,7 \%$ para $19,4 \%$ nas crianças de famílias com apenas um menor de cinco anos, e de $61,9 \%$ para $35,2 \%$ naquelas com dois ou mais menores de cinco anos. É pertinente dizer, entretanto, que houve 
reduções estatisticamente significantes em termos de ocorrência de anemia, tanto no grupo em que se verificou, quanto naquele em que não foi verificada a diluição intrafamiliar.

Tabela 15 - Distribuição das crianças, segundo prevalência de anemia por faixa etária, ao início e ao final do acompanhamento. São Paulo, 2003-2004.

\begin{tabular}{cccc}
\hline $\begin{array}{c}\text { Idade inicial } \\
\text { (meses) }\end{array}$ & $\begin{array}{c}\text { Prevalência inicial } \\
(\mathbf{\%})\end{array}$ & $\begin{array}{c}\text { Prevalência final } \\
(\mathbf{\%})\end{array}$ & $\begin{array}{c}\text { Idade final } \\
\text { (meses) }\end{array}$ \\
\hline $61-12$ & 75,3 & 56,8 & $121-18$ \\
$121-18$ & 66,2 & 48,2 & $181-24$ \\
$181-24$ & 66,7 & 51,1 & $241-30$ \\
$241-36$ & 33,3 & 15,0 & $301-42$ \\
\hline Total & $\mathbf{6 7 , 9}$ & $\mathbf{4 8 , 7}$ & Total \\
\hline
\end{tabular}

Gráfico 3 - Distribuição das crianças, segundo prevalência de anemia no início e ao final do acompanhamento. São Paulo, 2003-2004.

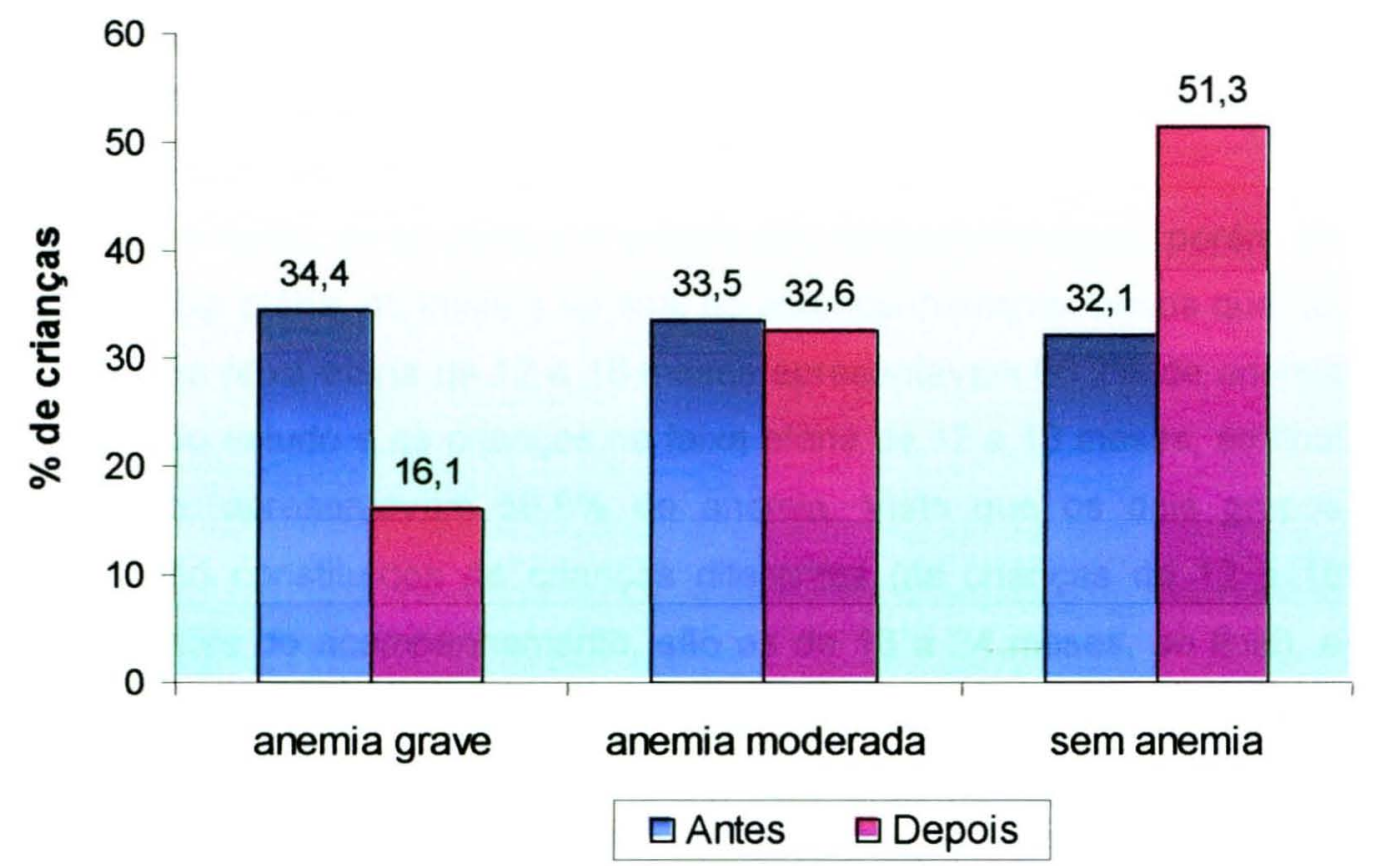

Comparando-se a prevalência de anemia, antes e após 6 meses de consumo de leite do Projeto VIVALEITE, somente em relação às crianças que participaram dos dois exames, pode-se observar uma melhora significativa. No início do acompanhamento, $67,9 \%$ das crianças apresentavam anemia, e ao final do acompanhamento, esse valor decresceu 
para $48,7 \%$, ou seja, $18,5 \%$ do total de crianças estudadas sairam do estado anêmico. Resultados semelhantes foram encontrados por TORRES et al. (1996), que verificaram uma diminuiçăo na prevaléncia de anemia, de 62,3\% para $41,8 \%$ em crianças menores de 4 anos, após 6 meses de consumo de leite fortificado com ferro quelato.

De acordo com o Gráfico 3, pode-se observar, ainda, que grande quantidade de crianças saiu do estado de anemia grave. Entre as crianças que apresentavam anemia grave no inicio do estudo, $78 \%$ melhoraram os índices de hemoglobina, sendo que destes, $44,2 \%$ passaram a apresentar anemia moderada e 33,8\% tornaram-se eutroficas, ao final de 6 meses. Entre as crianças que apresentavam anemia moderada no inicio do estudo, $42,7 \%$ tomaram-se eutróficas ao final do mesmo.

A tabela 15 evidencia uma melhora nos índices de hemoglobina em todas as faixas etárias estudadas, mas os resultados devem ser lidos com ressalvas, já que essa melhora pode ter ocorrido tanto pelo consumo de leite do VIVALEITE, quanto pela condição fisiológica, ou seja, pelo aumento da idade das crianças.

No entanto, ao se comparar grupos de crianças diferentes, porém, de mesma faixa etária, no início e ao final do acompanhamento, temos que, as crianças na faixa etária de 12 a 18 meses apresentavam $66,2 \%$ de anemia ao inicio do estudo e as crianças na faixa etária de 12 a 18 meses, ao final do estudo, apresentavam $56,8 \%$ de anemia. Visto que os dois grupos citados são constituidos de crianças diferentes (as crianças de 12 a 18 meses, antes do acompanhamento, são as de 18 a 24 meses, ao final), e que o primeiro grupo não havia recebido leite do VIVALEITE (ao contrário do segundo, o qual se beneficiou do produto), pode-se atribuir essa melhora ao consumo do alimento em pauta, somado à orientaçăo nutricional oferecida no momento do primeiro exame/entrevista, e não somente à condição fisiológica relativa ao aumento da idade. 


\subsection{Verificaçăo da adesão à orientação nutricional}

Tabela 16- Distribuição do $n^{\circ} e \%$ de crianças, segundo hábito de ferver o leite, antes e depois de orientação. São Paulo, 2003-2004.

\begin{tabular}{|c|c|c|c|c|c|c|}
\hline \multirow{3}{*}{$\begin{array}{l}\text { Hábito de ferver o } \\
\text { VIVALEITE antes }\end{array}$} & \multicolumn{4}{|c|}{ Hábito de ferver o VIVALEITE depois } & \multirow{2}{*}{\multicolumn{2}{|c|}{ Total }} \\
\hline & \multicolumn{2}{|c|}{ Năo Ferve } & \multicolumn{2}{|c|}{ Ferve } & & \\
\hline & $\mathbf{n}$ & $\%$ & $\bar{n}$ & $\%$ & $\mathbf{n}$ & $\%$ \\
\hline Nåo Ferve & 48 & 77,4 & $\overline{14}$ & 22,6 & 62 & 100,0 \\
\hline Ferve & 69 & 44,5 & 86 & 55,5 & 155 & 100,0 \\
\hline Total & 117 & $\overline{53,9}$ & 100 & 46,1 & 217 & 100,0 \\
\hline
\end{tabular}

$X^{2}=19,30$

Valor de $p$ nåo corrigido: 0,00

Tabela 17- Distribuiçăo do $n^{\circ} \mathrm{e} \%$ de crianças, segundo hábito de descartar a nata, antes e depois de orientaçăo. São Paulo, 2003-2004.

\begin{tabular}{lcccccc}
\hline \multirow{2}{*}{$\begin{array}{c}\text { Hábito de descartar } \\
\text { a nata antes }\end{array}$} & \multicolumn{2}{c}{ Hábito de descartar a nata depois } & \multicolumn{2}{c}{ Total } \\
\cline { 2 - 6 } & \multicolumn{2}{c}{ Năo Descarta } & \multicolumn{2}{c}{ Descarta } & \multicolumn{2}{c}{} \\
\cline { 2 - 7 } & $\mathbf{n}$ & $\%$ & $\mathbf{n}$ & $\%$ & $\mathbf{n}$ & $\%$ \\
\hline Năo Descarta & 114 & 92,7 & 9 & 7,3 & 123 & 100,0 \\
Descarta & 62 & 67,4 & 30 & 32,6 & 92 & 100,0 \\
\hline Total & $\mathbf{1 7 6}$ & $\mathbf{8 1 , 9}$ & $\mathbf{3 9}$ & $\mathbf{1 8 , 1}$ & $\mathbf{2 1 5}$ & $\mathbf{1 0 0 , 0}$ \\
\hline$X^{2}=$ & & & & &
\end{tabular}

$X^{2}=22,67$

Valor de $p$ nåo corrigido: 0,00

A maioria das mães ou responsáveis seguiu a orientação dada na primeira entrevista de năo ferver o leite do VIVALEITE e, em caso de necessidade, como a auséncia de geladeira ou aceitabilidade por parte da criança, ferver o leite, mas nåo descartar a nata, oferecendo-a a criança.

Vale dizer que a verificação do sucesso da orientação nutricional tem uma importância relevante, já que alguns estudos constataram a afinidade do ferro quelato com a gordura do leite, promovendo sua fixaçăo na nata formada em decorréncia do processo de fervura, em valores da ordem de 70\% (NAME 1995; TORRES et al. 1996).

Assim, seguida a orientaçăo de năo ferver o leite ou oferecer a nata à criança, tem-se a segurança de uma menor perda de ferro quelato adicionado ao leite. Ainda, visto que a vitamina $\mathrm{A}$ também adicionada ao leite constitui-se em elemento termosensivel, a ausência de fervura garante, do mesmo modo, a sua utilizaçăo de maneira mais completa. 
5.4. Comparaçőes entre a concentraçăo de hemoglobina e as caracteristicas da população estudada

Tabela 18 - Distribuiçăo do $n^{\circ}$ e \% de crianças, segundo características da populaçăo e concentraçăo de hemoglobina, no início do acompanhamento. Săo Paulo, 2003-2004.

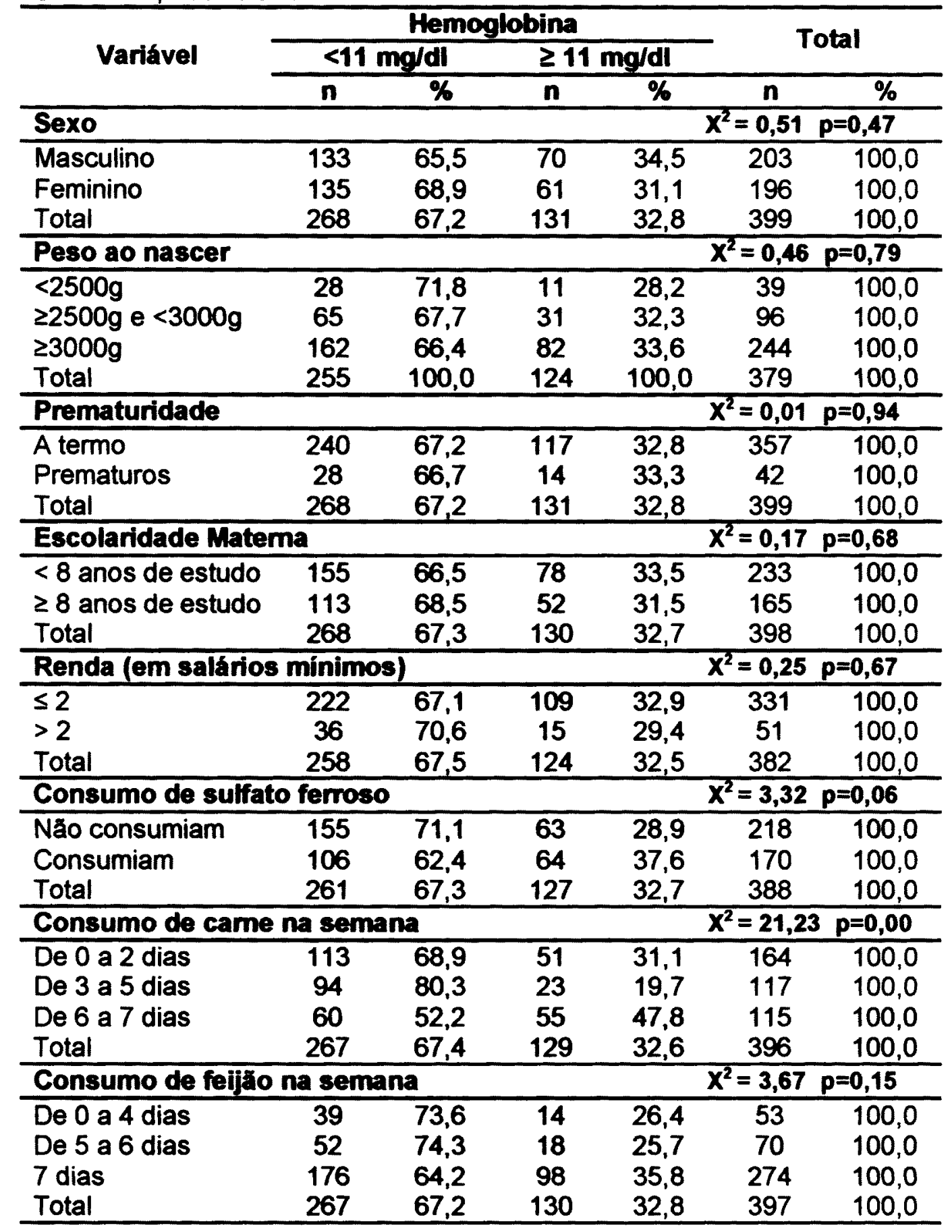


TORRES e QUEIROZ (1994) verificaram que a anemia era mais prevalente em crianças do sexo masculino $(63,1 \%$ em meninos, e $55,2 \%$ em meninas). O mesmo năo foi encontrado no presente trabalho, assim como nos estudos de NEUMAN et al. (2000), MONTEIRO et al. (2000) e LIMA et al. (2004).

Năo se observou associação significativa entre a prevalência de anemia nas crianças estudadas $e$ as variáveis peso ao nascer, prematuridade, escolaridade materna, renda, consumo de sulfato ferroso e consumo de feijåo.

MONTEIRO et al. (2000) verificaram que um aumento no poder aquisitivo das familias, bem como na escolaridade das mães não foi suficiente para aumentar os niveis de concentraçăo de hemoglobina de crianças menores de quatro anos, concluindo que a tendência de aumento da anemia ao longo dos anos pode dever-se ao baixo consumo de alimentos fontes de ferro.

LIMA et al. (2000) não encontraram associação entre as variáveis escolaridade matema, peso ao nascer, aleitamento materno e a prevaléncia de anemia, em crianças menores de 3 anos, no Sul do Brasil, mas encontraram associação positiva entre a idade e os índices de hemoglobina, com pico de prevalência nas crianças de 12 a 18 meses.

HADLER et al. (2002), em estudo sobre a etiologia da anemia em lactentes ( 6 a12 meses) de Goiânia, não encontraram associação entre a prevalência de anemia $e$ as variáveis escolaridade materna e renda per capita. Ainda, concluiram, mediante a utilização da combinação de vários parâmetros de diagnóstico, que a principal etiologia da anemia em lactentes de 6 a 12 meses confirma-se como ferropriva, ou seja, decorrente de um baixo consumo de alimentos fontes de ferro.

SILVA e col. (2002) năo encontraram associação estatistica entre prevalência de anemia e prematuridade. Das crianças nascidas com baixo peso, $66,7 \%$ eram anêmicas. No presente trabalho, das crianças nascidas com baixo peso, $71,8 \%$ eram anêmicas, mas a diferença não foi estatisticamente significante. 
ASSIS et al. (1997) năo encontraram associação estatisticamente significante entre escolaridade matema, renda per capita e prevalência de anemia em crianças de 1 a 72 meses de idade, no semi-árido da Bahia.

LIMA et al. (2004) verificaram que a renda per capita não se constituiu em fator associado aos niveis de hemoglobina. Porém, observaram associaçăo entre peso ao nascer, aleitamento materno exclusivo (<20 dias) e menores niveis de hemoglobina em crianças de 12 meses.

TORRES e QUEIROZ (1994) encontraram uma prevalência de anemia maior em crianças com peso inferior a $2.500 \mathrm{~g}$ em detrimento daquelas que nasceram com peso entre $2.500 \mathrm{~g}$ a $3.000 \mathrm{~g}$. Observaram, ainda, que em menores de 1 ano, havia associação estatisticamente significante entre a presença de anemia e o tempo de aleitamento materno. A prevalência foi de $62,7 \%, 60,6 \%, 57,3 \%$ e $55,5 \%$ nas crianças que nunca foram amamentadas, nas que foram amamentadas até 2 meses, nas que mamaram de 3 a 6 meses e nas que mamaram mais de 6 meses, respectivamente.

SPINELLI (2004) encontrou associaçăo positiva entre baixo peso ao nascer $(p<0,001)$, prematuridade $(p=0,005)$ e prevalência de anemia em crianças de ate 12 meses.

No presente estudo, a idade de desmame não foi comparada à prevalência de anemia, pois a maioria das crianças $(n=132)$ ainda se encontrava em aleitamento materno e a faixa etária estudada foi muito diversificada (entre seis e trinta e seis meses). Como referiram TORRES e QUEIROZ (1994), o reflexo do peso ao nascer, da prematuridade e do tempo de aleitamento matemo sobre as condiçōes de saúde da criança são mais possiveis durante o primeiro ano de vida. Pode-se observar que os estudos que verificaram associação entre peso ao nascer, aleitamento materno, prematuridade e prevaléncia de anemia, a averiguaram em crianças menores de 12 meses.

O fato de não se ter encontrado associaçăo entre renda e niveis de hemoglobina neste trabalho, pode dever-se à homogeneidade da amostra, composta, na sua totalidade, por familias com rendimentos inferiores a 0,5 
salário-mínimo per capita, ou ao fato da renda nāo se constituir, dentre as variáveis socioeconómicas, como único fator a ser considerado, dada a importância de outras, como saneamento básico e serviços de saúde, não contemplados neste estudo.

Quanto à suplementaçăo com sulfato ferroso, são comuns alguns efeitos colaterais como náuseas, vómitos, diarréia ou obstipação intestinal, em pacientes com tratamento oral (QUEIROZ e TORRES 2000; MASSEY 1992). É comum observar falta de adesão a esse tipo de tratamento por conta dos efeitos citados. ALMEIDA et al. (2004) observaram que o tratamento prévio com ferro năo teve influência sobre os niveis de hemoglobina de crianças de 12 a 72 meses. À semelhança deste, o presente estudo não verificou associaçăo entre a referência de consumo do suplemento e a prevalência de anemia. É pertinente salientar que não houve mensuraçăo do consumo e tempo de tratamento, apenas verificaçăo de uso ou năo no momento da entrevista.

Em relaçăo à alimentaçăo das crianças estudadas, apesar de ter-se verificado uma relaçăo estatisticamente significante na tabela 18 , não se pode dizer com certeza que as crianças que mais consumiam carne apresentavam menor prevalência de anemia. Constituiu em fato bastante evidente que as crianças que menos consomem carne (de zero a dois dias na semana) săo aquelas que mais apresentam anemia. Entretanto, esse resultado deve ser interpretado com cautela, já que as crianças que apresentaram um baixo consumo de came podem ser as de menor faixa etária. Nesse caso, a baixa idade seria um agravante para uma maior prevalência de anemia.

ASSIS et al. (1997) observaram tendéncia crescente de prevalência de anemia à medida que aumentou a adequaçăo na ingestăo de alimentos ricos em ferro, mesmo quando controlada pela idade da criança.

Apesar da tabela 18 apontar que as crianças que menos consumiam feijão apresentavam maior prevalência de anemia, essa diferença não foi significativa. Provavelmente por que, embora o feijăo possua um teor relativamente alto de ferro, este é pouco absorvido pelo organismo, mas, 
principalmente porque a quantidade oferecida à criança é, geralmente, muito pequena.

Tabela 19 - Distribuiçăo do $n^{\circ}$ e \% de crianças, segundo concentraçăo de hemoglobina e consumo diário de leite relatado pela mãe ou responsável, no inicio do acompanhamento. Săo Paulo, 2003-2004.

\begin{tabular}{|c|c|c|c|c|c|c|}
\hline \multirow{3}{*}{$\begin{array}{l}\text { Quantidade diária de } \\
\text { outro leite (em ml) }\end{array}$} & \multicolumn{4}{|c|}{ Hemoglobina } & \multirow{2}{*}{\multicolumn{2}{|c|}{ Total }} \\
\hline & \multicolumn{2}{|c|}{$<11 \mathrm{mg} / \mathrm{dl}$} & \multicolumn{2}{|c|}{$211 \mathrm{mg} / \mathrm{dl}$} & & \\
\hline & $n$ & $\%$ & $n$ & $\%$ & $n$ & $\%$ \\
\hline $0 \mapsto 480$ & 80 & 64,5 & 44 & 35,5 & 124 & 100,0 \\
\hline $480-1720$ & 55 & 55,0 & 45 & 45,0 & 100 & 100,0 \\
\hline $720-1960$ & 85 & 81,0 & 20 & 19,0 & 105 & 100,0 \\
\hline 960 e mais & 46 & 68,7 & 21 & 31,3 & 67 & 100,0 \\
\hline Total & 266 & 67,2 & 130 & 32,8 & 396 & 100,0 \\
\hline
\end{tabular}

A tabela 19 mostra que, no presente estudo, houve uma associaçăo positiva entre o consumo de leite de vaca e menor concentração de hemoglobina, concordando com estudo realizado por LEVY-COSTA e MONTEIRO (2004), que encontrou associaçăo positiva entre consumo desse leite e baixos niveis de concentraçăo de hemoglobina. Assim, pode-se dizer que as crianças estudadas consumiam grande quantidade de leite de vaca e ingeriam pouca quantidade de came, fatores que, associados à baixa faixa etária, podem ocasionar altos índices de anemia ferropriva.

Tabela 20 - Distribuiçăo do $n^{\circ}$ e \% de crianças, segundo concentraçăo de hemoglobina por faixa etária, no início do acompanhamento. Sảo Paulo, 2003-2004.

\begin{tabular}{|c|c|c|c|c|c|c|}
\hline \multirow{3}{*}{ Idade da criança } & \multicolumn{4}{|c|}{ Hemoglobina } & \multirow{2}{*}{\multicolumn{2}{|c|}{ Total }} \\
\hline & \multicolumn{2}{|c|}{$<11 \mathrm{mg} / \mathrm{dl}$} & \multicolumn{2}{|c|}{$\geq 11 \mathrm{mg} / \mathrm{dl}$} & & \\
\hline & $\bar{n}$ & $\%$ & $\bar{n}$ & $\%$ & $n$ & $\%$ \\
\hline $61-12$ & 121 & 76,6 & 37 & 23,4 & 158 & 100,0 \\
\hline $12 \vdash-18$ & 82 & 65,6 & 43 & 34,4 & 125 & 100,0 \\
\hline $181-24$ & 47 & 61,0 & 30 & 39,0 & 77 & 100,0 \\
\hline 24 e mais & 16 & 43,2 & 21 & 56,8 & 37 & 100,0 \\
\hline Total & 266 & 67,0 & 131 & 33,0 & 397 & 100,0 \\
\hline
\end{tabular}


A Tabela 20 evidencia uma associaçăo positiva entre a idade da criança e a prevalencia de anemia, constatando que as crianças de 6 a 12 meses săo as mais atingidas pela patologia, seguidas pelo grupo de 12 a 18 meses, fato reiterado por diversos estudos.

MONTEIRO et al. (2000) verificaram que a variaçăo da prevalência de anemia com a idade é intensa, indicando que o risco de deficiência aumenta muito ao longo do primeiro ano de vida, mantém-se elevado no segundo e retrocede a partir do terceiro. $O$ estudo verificou uma prevalência de anemia de $71,8 \%$ em crianças de 6 a 12 meses, com média de hemoglobina de $10,2 \mathrm{~g} / \mathrm{dL}$., valores muito semelhantes aos encontrados no presente trabalho.

SILVA et al. (2002) encontraram $60,8 \%$ de prevalência de anemia em crianças de 6 a 12 meses, sendo que destes, 55,6\% apresentaram anemia grave.

SPINELLI (2005), em publicação recente sobre concentração de hemoglobina em crianças, verificou um aumento na prevalência de anemia, conforme o crescimento da criança, sendo $61,1 \%$ aos 6 meses e $68,4 \%$ aos 12 meses.

ALMEIDA et al. (2004) encontraram uma correlaçăo positiva entre o fator idade $e$ as concentraçőes de hemoglobina e ferritina e correlação negativa entre o fator idade e os niveis de receptor de transferrina.

A auséncia de associaçăo entre as variáveis estudadas e a prevaléncia de anemia, com exceçăo para a idade da criança e o consumo de carne, vem corroborar dois fatos já reconhecidos pela literatura, o de que as crianças de 6 a 12 meses såo as mais susceptiveis à anemia ferropriva, e que a principal etiologia envolvida no desenvolvimento dessa patologia consiste em alimentaçăo quantitativa e qualitativamente deficiente, no que diz respeito a alimentos fontes de ferro. 
Tabela 21 - Distribuiçăo do $n^{\circ}$ e \% de crianças, segundo concentraçăo de hemoglobina e volume de leite do VIVALEITE, referido pelas mães ou responsáveis. Săo Paulo, 2003-2004.

\begin{tabular}{|c|c|c|c|c|c|c|}
\hline \multirow{3}{*}{$\begin{array}{l}\text { Quantidade diária de } \\
\text { VIVALEITE (em ml) }\end{array}$} & \multicolumn{4}{|c|}{ Hemoglobina } & \multirow{2}{*}{\multicolumn{2}{|c|}{ Total }} \\
\hline & \multicolumn{2}{|c|}{$<11 \mathrm{mg} / \mathrm{dl}$} & \multicolumn{2}{|c|}{$\geq 11 \mathrm{mg} / \mathrm{dl}$} & & \\
\hline & $n$ & $\%$ & $n$ & $\%$ & $n$ & $\%$ \\
\hline $150 \mapsto 480$ & 18 & 43,9 & 23 & 56,1 & 41 & 100,0 \\
\hline $480-1720$ & 42 & 51,2 & 40 & 48,8 & 82 & 100,0 \\
\hline $720-1960$ & 38 & 47,5 & 42 & 52,5 & 80 & 100,0 \\
\hline 960 e mais & 11 & 52,4 & 10 & 47,6 & 21 & 100,0 \\
\hline Total & 109 & 48,7 & 115 & 51,3 & 224 & 100,0 \\
\hline
\end{tabular}

A tabela 21 expressa a auséncia de associaçăo entre o aumento do consumo diário de leite do VIVALEITE e a diminuiçăo dos níveis de hemoglobina. Vale dizer que, a despeito de haver consumos diários distintos de leite, as crianças que o ingeriam em maior quantidade, faziam-no por menos vezes na semana, visto que o leite é suficiente para um consumo de apenas $0,5 \mathrm{~L}$ por dia. Assim, como já descrito a respeito da tabela 12, na tabela 21 trata-se, na verdade, do consumo de VVALEITE nos dias de entrega do mesmo às famílias, e năo do consumo durante todos os dias da semana.

Nota-se que as crianças que ingeriam a quantidade de leite preconizada pelo Projeto (0,5L por dia), e, assim, faziam-no durante todos os dias da semana, apresentaram menores prevaléncias de anemia, ainda que em valores não significativos.

Cabe mencionar, ainda, que a maioria das crianças que consumia mais de 0,5L de leite do VIVALEITE por dia, consumia, também, leite de vaca comum, ou seja, quando o volume de VIVALEITE ingerido era demasiado, o de leite de vaca também o era, na mesma proporção. Como descrito neste trabalho, e em outros estudos aqui mencionados, o consumo de leite de vaca está associado positivamente a maiores de prevalências de anemia. Assim, deve-se dizer que o consumo desse tipo de leite constituiuse em fator de influência no momento em que se desejou, neste estudo, comparar o consumo de leite do VIVALEITE à prevaléncia de anemia. 
Tabela 22 - Distribuiçăo do $n^{\circ}$ e \% de crianças, segundo concentração de hemoglobina por faixa etária, ao final do acompanhamento. São Paulo, 2003-2004.

\begin{tabular}{|c|c|c|c|c|c|c|}
\hline \multirow{3}{*}{ Idade da criança } & \multicolumn{4}{|c|}{ Hemoglobina } & \multirow{2}{*}{\multicolumn{2}{|c|}{ Total }} \\
\hline & \multicolumn{2}{|c|}{$<11 \mathrm{mg} / \mathrm{dl}$} & \multicolumn{2}{|c|}{$\geq 11 \mathrm{mg} / \mathrm{dl}$} & & \\
\hline & $\bar{n}$ & $\%$ & $n$ & $\%$ & $\bar{n}$ & $\%$ \\
\hline $12-18$ & 42 & 56,8 & 32 & 43,2 & 74 & 100,0 \\
\hline $181-24$ & 41 & 48,2 & 44 & 51,8 & 85 & 100,0 \\
\hline $24 \vdash 30$ & 23 & 51,1 & 22 & 48,9 & 45 & 100,0 \\
\hline 30 e mais & 3 & 15,0 & 17 & 85,0 & 20 & 100,0 \\
\hline Total & 109 & 48,7 & 115 & 51,3 & 224 & 100,0 \\
\hline
\end{tabular}

No início do acompanhamento, verificou-se uma associaçăo estatisticamente significante entre idade da criança e prevalência de anemia, constatando que a faixa etária de 6 a 12 meses foi a que apresentou menor concentraçăo de hemoglobina, seguida da faixa de 12 a 24 meses.

Ao final do acompanhamento, do mesmo modo, verificou-se associaçăo entre a prevalência de anemia e a idade da criança, evidenciando um aumento na concentraçăo de hemoglobina a partir dos dezoito meses. É consenso na literatura, que, a partir dos vinte e quatro meses, a prevalência de anemia tende a diminuir de forma linear (MONTEIRO e SZARFARC 1987; ROMANI et al. 1991; ASSIS 1997; OSORIO 2000; ALMEIDA et al. 2004; MONTEIRO et al., 2000; LIMA et al, 2000; NEUMAN et al, 2000). 


\subsection{Comparações entre a concentração de hemoglobina, no início e ao final do acompanhamento}

Tabela 23 - Distribuição das crianças, segundo média de concentração de hemoglobina no início e ao final do acompanhamento. São Paulo, 20032004.

\begin{tabular}{ccccc}
\hline $\begin{array}{c}\text { Hemoglobina } \\
\text { (g/dl) }\end{array}$ & $\mathbf{n}$ & $\begin{array}{c}\text { Média } \\
\text { (em g/dl) }\end{array}$ & Desvio-Padrão & $\begin{array}{c}\text { Mediana } \\
\text { (em g/dl) }\end{array}$ \\
\hline Antes do VIVALEITE & 224 & 10,18 & 1,51 & 10,30 \\
Depois do VIVALEITE & 224 & 10,99 & 1,58 & 11,0 \\
\hline
\end{tabular}

T pareado $=8,13$

$p=0,00$

TORRES et al. (1995), em estudo de suplementaçăo alimentar com leite enriquecido em ferro, encontraram, entre os momentos inicial e final, um incremento médio de $1,1 \mathrm{~g} / \mathrm{dL}$ nos niveis de hemoglobina de crianças de 6 a 23 meses, concluindo que a ingestăo suplementar diária entre 6 e 12 mg/ferro/dia ( 2 a 4 mamadeiras de $250 \mathrm{ml}$ por dia), por um período de 6 meses, foi suficiente para reduzir significativamente a caréncia de ferro na populaçăo estudada, podendo-se controlá-la com um periodo maior de tempo.

Assim, tem-se que o Projeto VIVALEITE, apesar de contar com um aporte diário menor de ferro, porém com um periodo maior de utilização, pode vir a desempenhar o efeito desejado, desde que utilizado da maneira preconizada pelos próprios critérios estabelecidos em sua normalização, incluindo o consumo absoluto pela criança beneficiária e a execução de orientaçăo nutricional às mães ou responsáveis. Portanto, existe um potencial efetivo, desde que se façam cumprir esses critérios.

Ainda, o incremento nos niveis de hemoglobina pode ter-se mostrado superior no estudo de TORRES et al., já que as crianças do estudo citado apresentaram, inicialmente, uma média maior de hemoglobina $(10,5 \mathrm{~g} / \mathrm{dL})$.

De qualquer modo, tanto o estudo supracitado quanto o aqui presente mostraram uma significância estatística (analisada por meio do teste $t$ pareado), em termos de aumento da média de concentração de hemoglobina após intervenção mediante leite enriquecido com ferro quelato. 
O estudo "Saúde e Nutrição das Crianças de Săo Paulo" (MONTEIRO 1988), assim como inúmeros outros, mostrou que há uma tendência de diminuição de hemoglobina em crianças até os 16-20 meses de idade, quando se inicia um aumento nos niveis de hemoglobina, possivelmente decorrente da alimentaçăo mais variada que a criança passa a ingerir, bem como da desaceleraçåo do crescimento, que promove uma diminuiçăo das necessidades de ferro. Assim, pode-se confundir uma resposta positiva decorrente da ingestăo de um alimento fortificado em ferro com o aumento da concentraçåo própria da físiologia da criança, em funçăo da idade.

Mesmo com essa ressalva, a discreta melhoria na concentração de hemoglobina sugere, por um lado, que o Projeto tem um efeito positivo nas crianças, e por outro lado, comparando-se com os resultados de TORRES et al. (1996), que o consumo deve ter sido inferior ao relatado pelas mães.

Tabela 24 - Distribuiçăo do $n^{\circ}$ e \% de crianças, segundo concentração de hemoglobina no inicio e ao final do acompanhamento. São Paulo, 20032004.

\begin{tabular}{|c|c|c|c|c|c|c|}
\hline \multirow{3}{*}{$\begin{array}{c}\text { Hemoglobina } \\
\text { antes }\end{array}$} & \multicolumn{4}{|c|}{ Hemoglobina depois } & \multirow{2}{*}{\multicolumn{2}{|c|}{ Total }} \\
\hline & \multicolumn{2}{|c|}{$<11 \mathrm{mg} / \mathrm{dl}$} & \multicolumn{2}{|c|}{$\geq 11 \mathrm{mg} / \mathrm{dl}$} & & \\
\hline & $\mathbf{n}$ & $\%$ & $\bar{n}$ & $\%$ & $\bar{n}$ & $\%$ \\
\hline $\begin{array}{l}<11 \mathrm{mg} / \mathrm{dl} \\
\geq 11 \mathrm{mg} / \mathrm{dl}\end{array}$ & $\begin{array}{l}93 \\
16\end{array}$ & $\begin{array}{l}61,2 \\
222\end{array}$ & $\begin{array}{l}59 \\
56\end{array}$ & 38,8 & $\begin{array}{c}152 \\
72\end{array}$ & 100,0 \\
\hline Total & 109 & 48,7 & 115 & 51,3 & 224 & 100,0 \\
\hline $\begin{array}{l}x^{2}=29,69 \\
p=0,00\end{array}$ & & & & & & \\
\hline
\end{tabular}

A tabela 24 mostra que as crianças obtiveram uma melhora significativa nos níveis de hemoglobina, reiterando os resultados já mencionados neste trabalho. 
Tabela 25 - Distribuiçăo das crianças, segundo concentração de hemoglobina no início e ao final do acompanhamento. São Paulo, 20032004.

\begin{tabular}{lccc}
\hline $\begin{array}{c}\text { Idade em } \\
\text { meses (n) }\end{array}$ & $\begin{array}{c}\text { Media de } \\
\text { Concentração de } \\
\text { Hb inicial } \\
\text { (em g/dl) }\end{array}$ & $\begin{array}{c}\text { Media de } \\
\text { Concentração de } \\
\text { Hb final } \\
\text { (em g/dl) }\end{array}$ & $\begin{array}{c}\text { Incremento } \\
\text { (em g/dl) }\end{array}$ \\
\hline $61-12(93)$ & 9,94 & 10,60 & 0,66 \\
$12-18(71)$ & 10,25 & 11,10 & 0,85 \\
$181-24(45)$ & 10,14 & 10,90 & 0,76 \\
24 e mais (15) & 11,50 & 12,26 & 0,76 \\
\hline Total (224) & $\mathbf{1 0 , 1 8}$ & 10,99 & $\mathbf{0 , 8 1}$ \\
\hline
\end{tabular}

De acordo com a tabela 25 , as crianças maiores de 12 meses foram as que apresentaram um maior incremento nos niveis de hemoglobina, em especial as de 12 a 18 meses, à semelhança do ocorrido no estudo de TORRES et al. (1996), que verificaram um maior incremento nos níveis de hemoglobina $(1,5 \mathrm{~g} / \mathrm{dL})$ em crianças de 12 a 23 meses, após consumo de leite fortificado com ferro quelato. 


\subsection{Consideraçס̃es sobre o Projeto Estadual do leite - VIVALEITE}

É importante referir que, para a narraçåo de todo o histórico e operacionalizaçăo do Projeto Estadual do Leite - VIVALEITE, incluindo os programas antecessores até a sua execuçăo atual, foi necessário utilizar-se do relato de funcionários da instituiçăo que estiveram presentes nos periodos estudados, bem como da leitura de Decretos, Resoluções e documentos internos, como Contratos, Oficios e Cartas, já que não havia, na SAA - CODEAGRO, um documento oficial que transcorresse sobre o Projeto.

\subsubsection{Sobre a operacionalização}

Durante a realizaçăo do trabalho de campo, foram encontrados alguns problemas inerentes à operacionalizaçăo do Projeto VIVALEITE, que, além de dificultarem o desenvolvimento do presente trabalho, conferem obstáculos para uma avaliaçăo do mesmo.

De acordo com o relato das entidades e municipios e de acordo com o observado nos mesmos locais (a coleta de dados foi realizada em dias de entrega de leite), nos dias de entrega sempre existem "sobras" de leite, dado que algumas måes năo comparecem para retirálo. Assim, essa "sobra" é distribuída para outras pessoas não cadastradas, que se apresentam ao local de entrega e aguardam para retirála, sob o prévio conhecimento de sua ocorrência. Essa prática determina uma dificuldade de avaliação do consumo de leite pela criança, uma vez que a maioria delas já fez uso do mesmo, seja por conta das "sobras", seja por ter recebido de outras pessoas, como parente, vizinho ou amigo. No momento da primeira entrevista, onde supostamente as crianças ainda năo faziam uso do leite (iriam ingressar no Projeto), traduziu-se em resposta comum, mediante questionamento sobre o consumo do leite, a ingeståo deste, principalmente porque algum parente ou conhecido era beneficiário do Projeto e dividia a sua cota de leite, mas também por meio do recebimento das "sobras". Consiste em prática comum o compartilhamento do leite entre os membros da familia que residem ou não no mesmo domicilio. 
A observação da ausência das mães no momento de entrega de leite revela um comportamento comum, verificado também, por ocasião do não comparecimento das mesmas, na data agendada para a segunda entrevista/exame. Tal fato pode ser devido a uma falta de interesse intrínseco do comportamento dessa populaçăo no que se refere a um benefício doado pelo govemo elou a uma falta de compromisso com o Projeto.

Quanto à distribuiçăo de leite para pessoas não cadastradas, não se observou uma prática comum entre as entidades e municipios, sobre a quem doar as "sobras", cabendo à instituiçăo esse tipo de decisão. Não raro, essas "sobras" de leite são entregues a instituiçőes como creches e orfanatos, e até mesmo para pessoas idosas. Essa disposição arbitrária faz com que se desvirtuem os critérios do Projeto. Desse modo, seria pertinente uma recomendaçăo por parte da SAA, indicando que as "sobras" sejam entregues a pessoas que atendam aos critérios exigidos pelo Projeto.

Outra dificuldade encontrada na coleta de dados foi a falta de entendimento, por parte dos responsáveis pelo VIVALEITE nas entidades e municipios, dos pré-requisitos estabelecidos para o desenvolvimento adequado da mesma. Para a realizaçăo do exame, solicitou-se a essas pessoas que fossem convocadas crianças na faixa etária de 6 a 24 meses de idade, antes de sua inscriçăo no Projeto. A despeito da solicitaçăo, compareceram crianças já inscritas e de diferentes faixas etárias. Tal fato, além de comprometer o tamanho da amostra e os objetivos do trabalho, revelou o năo cumprimento dos critérios do próprio Projeto, dado que grande parte das crianças que compareceram eram aquelas que ingressariam no VIVALEITE, mesmo sem apresentar a faixa etária prioritária estabelecida.

É pertinente salientar que, por diversos fatores, fossem eles, a distância percorrida pela mãe, a solicitação desta, por achar que a criança sofria de anemia, entre outros, a equipe foi compelida à realizaçăo do exame em crianças que năo apresentavam os critérios pré-determinados pela pesquisa. 
Os fatos supracitados revelam a necessidade de uma pesquisa de campo, por parte da SAA - CODEAGRO, a fim de avaliar a adesão aos critérios e à operacionalizaçăo do Projeto. Ainda, revelam a necessidade da existência de palestras e reunióes para treinamento e reciclagem no que diz respeito as características do Projeto, bem como aos aspectos nutricionais relativos ao leite distribuido.

Em relaçăo à logística de distribuiçăo do leite, identificou-se um fato curioso. A entrega de leite nos municipios do interior do Estado de São Paulo acontece por trés vezes na semana, possibilitando o consumo, pela criança beneficiária, de meio litro de leite por dia, ingestăo pretendida pelo próprio Projeto. No entanto, no Municipio de Sảo Paulo, esta entrega é realizada nas entidades por duas vezes na semana, impedindo o consumo do leite doado somente pela criança favorecida, uma vez que, se este não for consumido por outrem, a ingestão, pela mesma, dar-se-á posteriormente à data de validade do produto (três dias). Assim, o próprio sistema de distribuiçăo de leite na Capital favorece à diluiçăo intrafamiliar do benefício recebido.

VISKI (2004), em estudo do Projeto VIVALEITE no Municipio de Santo André, verificou que, em relaçăo à distribuiçăo do leite, ocorria um intervalo de tempo entre a passagem de um mès para o outro, onde as famílias năo recebiam o beneficio (periodo de, pelo menos, 6 dias). Também constatou que algumas entidades entregavam o leite às famílias até 4 horas após a chegada do caminhăo de entrega.

Mediante relato de funcionários e presença em palestras ministradas para os municipios e entidades, observou-se que, em muitos casos, o laticinio contratado pelo govemo nåo atende às disposições do contrato, entregando o leite duas vezes por semana nos municipios (onde seriam três) e uma vez por semana nas entidades (onde seriam duas).

Ainda, nåo raro o fato supracitado ocorre por solicitaçăo dos próprios responsáveis pelo Projeto nas entidades e municipios. Pode-se cogitar que esse tipo de comportamento aconteça por conta da falta de informação sobre a operacionalizaçăo do Projeto ou pela busca de uma altemativa que 
demande menos trabalho aos agentes envolvidos, aliada à confiança dos mesmos na auséncia de fiscalizaçăo nesse sentido.

Assim, nota-se uma negligência da SAA - CODEAGRO no que diz respeito ao controle do Projeto no âmbito de sua execuçăo, já que os locais de entrega do leite seriam o espaço mais apropriado para uma avaliação da operacionalizaçăo do mesmo, açăo pouco desenvolvida pelos seus gestores.

Outro fato que, por um lado favoreceu a execução do presente estudo, mas por outro, revelou a falta de monitoramento do Projeto em relaçáo ao cadastramento dos beneficiários, consistiu no descumprimento de uma norma estabelecida. Por força de mudanças ocomidas no Projeto no ano de 1997, este passou a distribuir, nos municípios do interior do Estado de Såo Paulo, 15 litros de leite por criança, por mês (ao invés de 30, cota distribuida até a data citada). Dessa forma, todos os municípios, a partir dessa data, deveriam cadastrar o dobro de crianças que costumavam atender. Como observado neste trabalho, esta norma só foi executada (pelos municípios aqui estudados) seis anos depois (em 2003). Faz-se importante explanar ainda, que, frente a essa determinação, algumas prefeituras custearam o leite (năo fortificado) para as novas crianças, ao invés de diminuir a quantidade de leite daquelas já cadastradas. Desse modo, a despeito de todas as crianças estarem cadastradas no VIVALEITE, algumas recebiam leite fortificado, outras năo. Face ao descrito, cabe dizer que a CODEAGRO năo possui informaçóes a respeito de quais e quantos municipios assim procedem, concluindo-se que deve haver crianças que não recebem leite fortificado, apesar de inscritas no Projeto VIVALEITE.

Os municipios estudados neste trabalho não realizavam complementaçăo do leite doado, mas também năo haviam cumprido a norma citada, estando em fase de cadastramento de novas crianças.

Ainda em relaçăo a problemas relativos a operacionalizaçăo do Projeto, que decorrem em dificuldades de realizaçăo de estudos de avaliaçăo de resultados, é pertinente salientar que cada entidade/município beneficiado já tem sua cota (quantidade a ser distribuida) de leite 
estabelecida, sendo bastante incomuns episódios de aumento ou diminuição desses volumes. Dessa maneira, qualquer estudo que pretenda estudar a condiçăo anterior e posterior ao beneficio apresenta dificuldades em ser realizado, em decorréncia da falta de representatividade de amostras, como observado neste estudo.

No tocante aos critérios de atendimento, a prioridade principal consiste em cadastrar familias que recebam menos de 2 salários mínimos. $O$ presente estudo, assim como outros (MONTEIRO et al. 2000; HADLER et al. 2002; ALMEIDA et al. 2004) năo encontrou associaçăo significativa entre renda e prevaléncia de anemia. No entanto, é reconhecido na literatura o fato de que a anemia ocorre significantemente com maior prevaléncia em crianças de 6 a 24 meses (QUEIROZ e TORRES 2000; MAHAN e STUMP 1998; SZARFARC et al. 1995; FREIRE 1998). OSORIO (2002), em estudo sobre os determinantes da anemia em crianças, conclui que a urgência para o tratamento da anemia ferropriva se faz no grupo etário de maior risco - 6 a 23 meses - que deve ser priorizado nos programas de saúde e nutriçăo.

VISKI (2004) relatou em seu estudo no Municipio de Santo André, que as entidades têm seus próprios critérios de inclusão de beneficiários e a maioria delas nåo segue a prioridade da faixa etária (6 a 24 meses). Ainda, observou que, năo raro, quando uma criança é excluída do Projeto por completar 7 anos, há uma substituiçăo automática por seu irmăo menor, independente da faixa etária, concluindo que esses fatos podem gerar uma situaçăo de clientelismo e exclusăo de crianças mais vulneráveis a desvios nutricionais.

Assim, se o Projeto VIVALEITE tivesse por critério primordial a faixa etária, secundada pela renda, maior número de crianças de risco para anemia seriam atendidas e aumentaria a possibilidade de controle da deficiência de ferro, como visto neste trabalho. Além disso, o Projeto constituiria em medida emergencial, e nåo em projeto assistencialista, onde as familias se perpetuam no recebimento do beneficio. 


\subsubsection{Sobre a informação nutricional}

Entre as medidas para o aumento do consumo de ferro da dieta, podem ser consideradas, o aumento do consumo habitual de alimentos fontes de ferro e a mudança de práticas alimentares que levem à combinação dos alimentos fontes com aqueles que favorecem a absorção do mineral e a diminuiçăo do consumo de inibidores da absorção do nutriente às refeiçőes (chá, café, excesso de fibras de cereais, leite de vaca e derivados). Essas mudanças requerem programas educativos $\mathrm{e}$ informativos paralelos, de boa qualidade, disponiveis para a população (SZARFARC et al. 1995).

Nesse sentido, o trabalho em questão, pela ciência da importância da educaçăo nutricional como forma de controle da anemia, realizou orientação nutricional no momento da primeira entrevista, abordando temas essenciais para preencher os requisitos supracitados. Entretanto, tal ação deveria traduzir-se em parte intrinseca do Projeto VIVALEITE, devendo ser realizada constantemente, para os gestores e para os beneficiários do Projeto, principalmente no momento em que novas familias e novas entidades são cadastradas, o que náo é realizado atualmente.

QUEIROZ e TORRES (2000), em artigo sobre anemia ferropriva na infáncia, também concluem que a falta de conhecimento sobre as características da alimentaçăo acaba por levar a práticas alimentares inadequadas. Esse pode ser o mesmo tipo de problema que leva à diluição intrafamiliar do leite do VIVALEITE, ou seja, a mãe, por falta de conhecimento da gravidade da anemia para o desenvolvimento global de seu filho, associada à falta de informação sobre a importância nutricional do leite, acaba por não priorizar o consumo pela criança beneficiária, distribuindo o produto a todos os membros da familia. 


\subsubsection{Sobre o controle de qualidade do leite}

Quanto ao controle de qualidade do leite do Projeto VIVALEITE, existe uma falha no que diz respeito à fortificação do leite, já que a única garantia da presença de ferro e vitaminas no produto consiste em análise quantitativa, năo sendo possivel determinar se o ferro adicionado é realmente um produto quelado. Além disso, năo existe recomendação, por parte da SAA - CODEAGRO, sobre o procedimento correto de adição do mix de vitaminas ao leite. Assim, deveria haver um sistema de vigilância para o controle de qualidade do leite, envolvendo açöes de monitoramento, desde a adição do mix de vitaminas até o momento da distribuição para as familias.

SOGLIA (2001), em estudo sobre os aspectos tecnológicos e nutricionais da fortificação de leite com ferro, afirma que o método de adição de ferro ao leite com uso de compostos solúveis, como o ferro aminoácido quelato, é bastante simples, bastando dissolver a fonte de ferro no tanque de leite, antes da pasteurização e homogeneização, sem necessidade de outros equipamentos, além daqueles já existentes nos laticínios. Assegura, ainda, que para uma boa homogeneidade, deve-se realizar uma pré-mistura, dissolvendo-se o composto em uma pequena quantidade de leite, especificamente, $0,5 \%$ do total de leite a ser enriquecido (de acordo com a Figura 1).

Assim, seria pertinente haver, por parte da equipe técnica da SAA CODEAGRO, um treinamento para os laticínios, abordando o método correto de adiçăo do mix de vitaminas ao leite, bem como um monitoramento de sua execução, por meio de visitas aos mesmos. Ainda, a fim de garantir a adiçăo do mix ao leite do Projeto, deveria ser solicitada aos laticínios a nota fiscal de compra do produto, já que em posse destas é possivel rastrear os lotes do mesmo, via distribuidora, possibilitando o conhecimento da qualidade do mix de vitaminas adquirido pelos laticínios. 
Figura 1 - Fluxograma de adiçåo de ferro ao leite

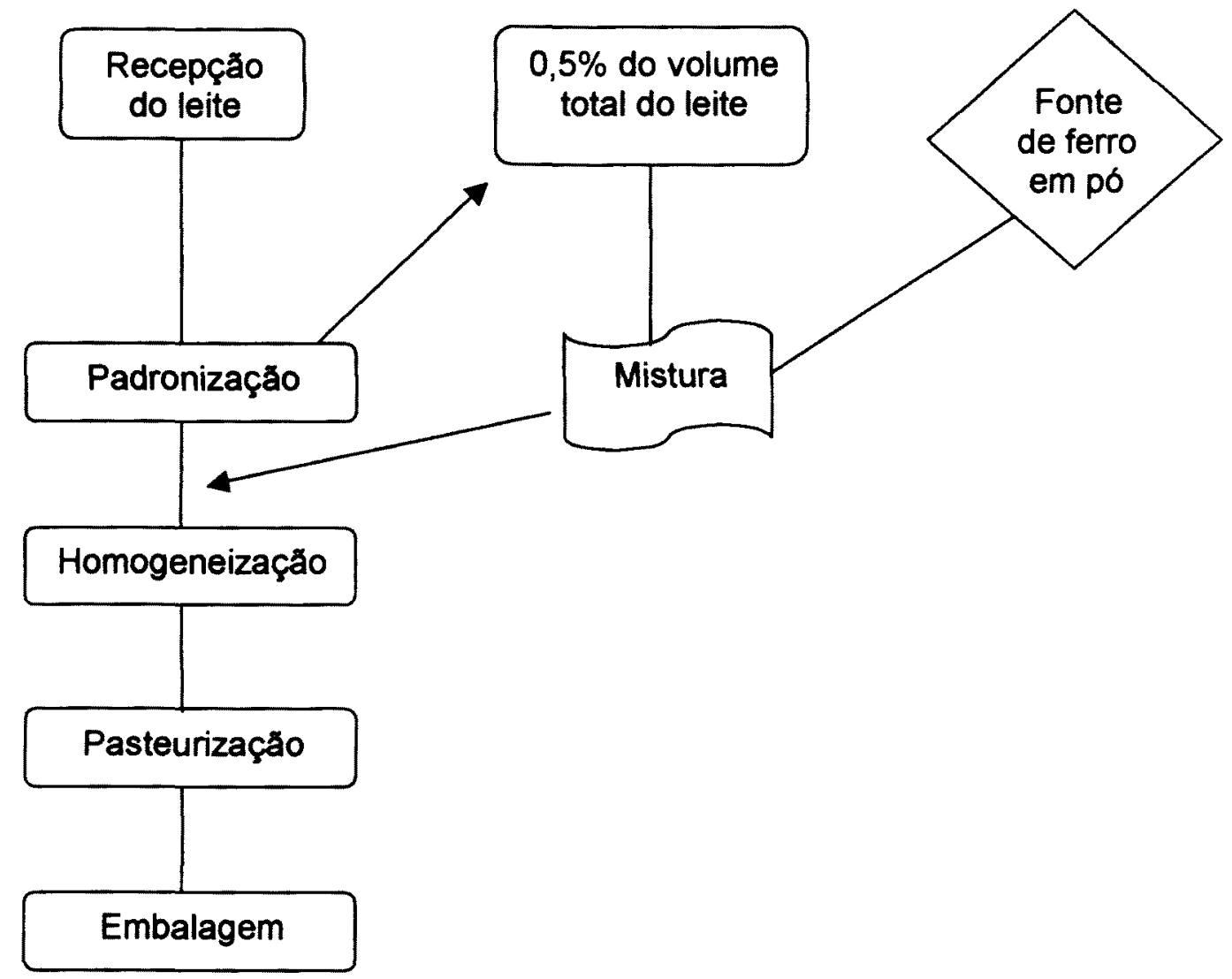

Fonte: SOGLIA (2001) 


\subsubsection{Sobre a avaliação nutricional}

No que se refere à avaliação do Projeto VIVALEITE, nota-se que, atualmente, os maiores esforços nesse sentido são em direçăo a um controle da qualidade do leite distribuido. Quanto à avaliaçăo nutricional, além de alguns projetos esparsos sobre prevalência de anemia, há uma tentativa de avaliaçăo do estado nutricional das crianças, por meio das medidas de peso e estatura e dados de saúde preenchidos em um novo formulário de cadastro, utilizado a partir do ano de 2003, conforme já mencionado neste trabalho. Faz-se essencial aludir para o fato de que, desde o Decreto 44.459, de 22 de dezembro de 1999, o qual instituiu o Projeto VIVALEITE, estabeleceu-se, mediante a Minuta de Convênio (entre a SAA - CODEAGRO e os municípios do interior do Estado de São Paulo), a obrigatoriedade dos municípios de "realizar o acompanhamento nutricional das crianças, com supervisăo de profissionais da área de saúde e envio periódico de informaçరes sobre os resultados alcançados". Entretanto, como relatado anteriormente, a cobrança dessa prática somente aconteceu a partir do ano de 2003.

Assim, nota-se que mudanças no sentido de avaliar os resultados do Projeto ocorrem lentamente e de maneira incompleta, já que, além da SAA CODEAGRO apenas receber os cadastros, sem haver, até o momento, a possibilidade de avaliar os resultados, essa prática só é desenvolvida nos municípios do interior do Estado de Săo Paulo, sem menções de se concretizar no municipio de Săo Paulo. 


\subsubsection{Sobre a intersetorialidade}

Em 1997, como descrito neste trabalho (Decreto 41.612, de 07 de março), instituiu-se a Comissão Estadual, com representantes de outras Secretarias de Estado conveniadas, visando uma maior integração e ações conjuntas do poder Público para o aprimoramento do Programa.

É importante ressaltar que, de acordo com o relato de funcionários da SAA que prestavam serviço desde o ano citado, em detrimento de sua instituiçăo legal, tais comissōes nunca se reuniram no intuito de avaliar os resultados e ditar melhorias para o Projeto VIVALEITE, exceto para discutir a elaboração da Resoluçăo SAA - 24, de 1 de agosto de 2000. Mudanças significativas poderiam ter sido cogitadas e efetuadas se os membros da Comissão houvessem se reunido para discutir, por exemplo, uma forma de avaliaçăo do Projeto, visto que, atualmente, consistem em meios de avaliação do mesmo, como já citado, apenas o recente sistema de controle de qualidade do leite e o acompanhamento antropométrico realizado nos municípios do interior do Estado, este último, ainda carente de resultados por falta de um sistema informatizado para maximizar a sua execução.

Particular importância se dá à ausência da participação da Secretaria de Estado da Saúde (membro da Comissão supracitada) como parceira no desenvolvimento e avaliaçăo dos resultados obtidos com o Projeto, já que a intersetorialidade consiste em parte essencial, nos dias de hoje, para o desenvolvimento e execução de qualquer programa de política pública e de nutriçăo. Nesse sentido, essa conjugação deveria ser implantada e concretizada no intuito de avaliar o Projeto como um todo e especificamente o impacto deste na saúde dos beneficiários. 


\section{CONCLUSÃo}

O presente estudo verificou uma prevalência de anemia de $67,2 \%$ em crianças de 6 a 36 meses ( $n=399$ ), no início do acompanhamento, à semelhança de diversos outros estudos, evidenciando que a anemia ferropriva continua a ser um problema de Saúde Pública, instalando-se precocemente, e atingindo, ainda, com gravidade elevada, as crianças maiores de 1 ano.

Observou-se, ainda, que a anemia está mais intensamente relacionada à deficiência alimentar do que a outros fatores, como escolaridade materna, renda, peso ao nascer e prematuridade, conforme descrito, igualmente, por outros autores.

Comparando-se os grupos que participaram dos momentos inicial e final da pesquisa ( $n=224$ ), póde-se averiguar uma melhora importante na concentraçăo de hemoglobina das crianças e conseqüente diminuição da prevalência de anemia, após a intervençăo.

No início do estudo, 67,9\% das crianças apresentavam anemia. Após 6 meses de consumo do leite do VIVALEITE, esse valor decresceu para $48,7 \%$, ou seja, $18,5 \%$ do total de crianças estudadas saíram do estado anêmico. Póde-se constatar, ainda, que grande quantidade de crianças saiu do estado de anemia grave. Entre as crianças que apresentavam anemia grave no início do estudo, $78 \%$ melhoraram os indices de hemoglobina, sendo que $33,8 \%$ tornaram-se eutróficas, ao final de 6 meses.

A média de concentração de hemoglobina, após 6 meses de consumo de VIVALEITE, aumentou significativamente $(p=0,00)$, de $10,18 \mathrm{~g} / \mathrm{dL}$ para $10,99 \mathrm{~g} / \mathrm{dL}$, havendo um incremento de $0,81 \mathrm{~g} / \mathrm{dl}$ nos niveis de hemoglobina das crianças beneficiárias.

Apesar do estudo ter verificado uma diluição intrafamiliar do leite distribuido, este não se constituiu em fator de impedimento para a melhora nos índices de hemoglobina das crianças beneficiárias.

Além disso, foi possível verificar a adesăo às orientaçőes nutricionais dadas no início do estudo, por meio da diminuiçăo da quantidade de familias 
que procediam à fervura do leite e ao descarte da nata formada, mostrando que, ao se executar uma prática de educação nutricional, pode-se notar resultados concretos.

Visto que o principal objetivo das intervençōes nutricionais é aumentar as reservas orgânicas de ferro de uma populaçăo-alvo, o trabalho em queståo alcançou as expectativas esperadas em um projeto de suplementaçăo alimentar, já que verificou resultados positivos no que concerne a melhoria do estado nutricional de ferro das crianças beneficiárias do Projeto VIVALEITE. Salienta-se que essa melhora pode-se dever ao consumo do leite, bem como pode estar vinculada à orientação nutricional oferecida às măes ou responsáveis pelas crianças.

Possivelmente a melhora observada nos niveis de hemoglobina das crianças tenha ocorrido em razăo do delineamento do estudo, que promoveu a execuçăo das condiçð̌es essenciais para um plano de suplementação alimentar. Desse modo, os resultados positivos devem estar relacionados ao consumo do leite fortificado, somado às orientaçőes nutricionais fornecidas no inicio da pesquisa, fato que reitera a importáncia da educaçăo nutricional para alcançar a efetividade de um projeto dessa relevância.

Assim, o estudo aqui apresentado, como diversos outros, mostra que a estratégia de utilizaçăo de distribuição de algum tipo de alimento fortificado com ferro para a população de baixa renda traduz-se em intervenção altamente efetiva no controle e no combate à anemia ferropriva, com forte respaldo na literatura, desde que acrescido de estratégias fundamentais à sua execuçăo, salientando-se o controle de qualidade, a informação nutricional e os métodos adequados de avaliação. 


\section{Consideraçסes finais}

Está plenamente difundido e aceito pela literatura o fato de que um programa de suplementação alimentar se mostra bastante efetivo para prevençăo e controle da anemia ferropriva, desde que se estabeleçam regras rigidas de controle de qualidade e avaliaçăo desse tipo de intervenção.

O Projeto VIVALEITE conta com diversos fatores positivos que condizem com as perspectivas a serem adotadas para o controle $e$ prevençăo da anemia ferropriva:

- consiste em projeto de suplementaçăo que faz uso de um alimento largamente consumido pela população infantil para veiculo de fortificação - 0 leite;

- utiliza um tipo de ferro comprovadamente de alta biodisponibiidade e que nåo ocasiona alteraçőes nas características organolépticas do produto ferro aminoácido quelato;

- faz uso da combinaçăo de ferro com vitaminas $A$ e $D$, também de grande importância para a saúde infantil, além da vitamina A participar do processo de absorção e transporte do ferro, e da vitamina $D$ auxiliar na absorção do cálcio presente no leite;

- estabelece prioridade de atendimento devidamente respaldado na literatura - crianças de 6 a 23 meses, que săo mais susceptiveis à ocorréncia de anemia ferropriva;

- está iniciando um sistema mais rígido para o controle de qualidade do produto oferecido;

- está iniciando projetos relativos à educação nutricional, embora ainda de forma descontínua;

- está iniciando projeto de avaliaçăo nutricional das crianças beneficiárias, embora consista em procedimento incipiente.

Ainda, o Projeto tem sua relevåncia no sentido em que visa complementar a alimentação de crianças sabidamente alimentadas insuficientemente ao seio, que fazem uso de leite de vaca e que consomem pequenas quantidades de alimentos fonte de ferro, conforme observado 
neste trabalho, buscando complementar as necessidades desse mineral inerentes à faixa etária prioritária.

Embora os aspectos positivos sejam de extrema relevância, é preciso apontar alteraçס̋es necessárias para o aprimoramento do Projeto, no intuito de maximizar os seus resultados para a população beneficiada.

Propóe-se:

Revisão dos critérios, tornando a principal prioridade a faixa etária, ou restriçăo do atendimento para crianças menores de 4 anos (ou mesmo exclusivo a crianças de 6 a 24 meses). Destaca-se que, atualmente, a populaçăo de pré-escolares e escolares conta com a cobertura de programas de suplementação alimentar, como o enriquecimento das farinhas com ferro;

> Pesquisa de campo rotineira (a ser realizada nos locais de distribuiçăo do leite) para avaliaçăo do cumprimento dos critérios propostos pelo Projeto e das condiçőes dos locais de entrega do leite;

Alteraçōes na logística de distribuiçăo do leite, incluindo o aumento nos dias de entrega no Município de São Paulo;

Realizaçăo de palestras informativas, de forma permanente, para os responsáveis pelo Projeto e para os beneficiários, abordando os critérios, a importância nutricional e os cuidados para melhor utilização do leite distribuido;

> Implantação de parcerias, principalmente em relação à Secretaria de Estado da Saúde. A instauração de parcerias entre as Secretarias de Estado permite que açőes, como programas de incentivo ao aleitamento materno, educaçăo nutricional, melhoria da qualidade da dieta, controle de infecções, entre outras, demasiadamente importantes no intuito de prevenir e controlar a anemia ferropriva, possam ser realizadas de maneira conjunta e de forma efetiva e integral. 


\section{REFERÊNCIAS BIBLIOGRÁFICAS}

Almeida CAN et al. Avaliação do estado nutricional de ferro na criança. Rev Pau Pediatr. 2002; 20:37-41.

Almeida LCM, Naves, MNV. Biodisponibilidade de ferro em alimentos e refeiçסes: aspectos atuais e recomendaçסes alimentares. Pediatria Moderna. 2002; XXXVIII (6): 272-326.

Almeida CAN, Ricco RG, Del Ciampo LA, Souza AM, Pinho AP, Oliveira JED. Fatores associados a anemia por deficiência de ferro em crianças préescolares brasileiras. Jornal de Pediatria. 2004; 80(3):229-34.

Andrade KC. A escolha de alimentos para fortificação com ferro. Săo Paulo; 2001. [Dissertaçăo de mestrado - Curso de Pós-Graduação Interunidades em Nutriçăo Humana Aplicada. FCF/FEAFSP - USP].

Angelis RC, Ctenas MLB. Biodisponibilidade de ferro na alimentação infantil. São Paulo; 1993. (Nestlé: Serviço de Informaçăo Científica - Temas de Pediatria número 52).

Arraval SRM. Consumo de ferro suplementar no controle da anemia. São Paulo; 2001. [Dissertação de mestrado - Faculdade de Saúde Pública USP]

Ashmead HD. Conversations on chelations and mineral nutrition. New Canaan, Connecticut: Keats Publishing, 1989.

Assis AMO, Santos LMP, Martins MC, Araújo MPN, Amorim, DQ, Morris SS, Barreto, ML. Distribuiçăo da anemia em pré-escolares do semi-árido da Bahia. Cad. Saúde Pública [Periódico on-line] 1997; 13 (2). Disponível em URL:http://uww.scielo.br [2005 junho 22].

Beard JL, Connor JR, Jones BC. Iron in the brain. Nutr. Rev. 1993; 10:51: 157. 
Beard JL, Dawson H, Piñero DJ. Iron metabolism: a comprehensive review. Nutr Rev. 1996; 54:295:317.

Beard JL. Iron deficiency: assessment during pregnancy and its importance in pregnant adolescents. Am J Clin Nut. 1994; 59 suppl: 502s-10s.

Bothwell TH. et al. Nutritional iron requirements and food iron absorption. Journal of Internal Medicine. 1989; 226: 357-65.

Brasil. Ministério da Saúde. Secretaria de Política de Saúde. Organização Pan Americana da Saúde. Guia alimentar para crianças para crianças menores de dois anos. Brasilia: Ministério da Saúde, 2002a. 152p. (Série A - Normas e Manuais Técnicos; $\left.n^{\circ} 107\right)$.

Brasil. Ministério da Secretaria de Vigilância Sanitária. Portaria $n^{\circ} 27$, de 13 de janeiro de 1998. Estabelece o Regulamento Técnico referente à informaçăo nutricional e complementar. Diário Oficial da União, Brasília, 16 jan 1998. Seção 1.

Brasil. Ministério da Secretaria de Vigilância Sanitária. Portaria $n^{\circ} 31$, de 13 de janeiro de 1998, republicada em 30 de março de 1998. Estabelece o padrăo de identidade e qualidade de alimentos adicionados de nutrientes. Diário Oficial da União, Brasilia, 30 mar 1998, Seçăo I.

Bresolin AMB, Issler H, Bricks LF, Lima IN. Alimentação da criança normal. In: Sucupira ACSL et al. Pediatria em consultório. Săo Paulo; 2000. p.6182.

Brunken G, Szarfarc SC. Anemia ferropriva em pré-escolares: consequências, formas de controle e histórico das políticas nacionais para reduçăo da deficiência. Cadernos de Nutrição (SBAN). 1999; 17: 1-19.

Brunken G, Szarfarc SC. Ferro: metabolismo, excesso e toxicidade e recomendaçס̋es. Cadernos de Nutrição (SBAN). 1999; 18: 23-35. 
Calvo EB, Gnazzo N. Prevalence of iron deficiency in children aged nine to 24 months from a large urban area of Argentina. Am J Clin Nutr. 1990; $52: 534-40$.

Castro IRR. Efetividade da suplementaçăo alimentar na recuperação nutricional de crianças: avaliação do Programa “Leite é Saúde” (PLS) no município do Rio de Janeiro. Sảo Paulo; 1999. [Tese de doutorado UFRJ].

Cavalcanti NF, Ribeiro H. Condiçðes socioeconómicas, programas de complementaçăo alimentar e mortalidade infantil no Estado de São Paulo (1950 a 2000). Saúde e Sociedade. 2003; 12 (1): 31-42.

CDC (Center for disease control and prevention)MHO (World Health Organizacion). Epi Info 6, version 5.04. A world processing, database and statistics program for public health. Attanta: CDC/Geneva:WHO, 1996.

Cintra IP, Oliveira CL, Vellozo, EP, Fagioli D, Siva, R, Aires AP, Fisberg, M. Utilizaçăo de leite fortificado com ferro na merenda escolar do municipio de Săo Paulo. Pediatria Modema. 2002; 38 (10), 475-79.

Cook JD, Baynes RD, Skikne BS. Iron deficiency and the measurement of iron status. Nutr Res Rev. 1992; 5:189-202.

Cook JD, Finch CA. Assessing iron status of a population. Am J Clin Nutr. $1979 ; 32: 2115-9$.

Cook JD. Adaptation in iron metabolism. Am J Clin Nutr. 1990; 51:301-8.

Cook JD. Clinical evaluation of iron deficiency. Semin Hematol. 1982; 19: 6-18.

Cook JD. Iron: methods in hematology. London: Churchil Livinstone; 1980. v.1. 
Dallman PR \& Siimes MA. Iron deficiency in infant and childhood: a report of the Intemational Nutritional Anemia Consultative Group (INACG). Washington, D.C: The Nutrition Foundation; 1979.

Dallman PR \& Yip R. Hierro. In: Ziegler EE; Filer JR. Conocimientos Actuales sobre Nutrición. $7^{\mathbf{a}}$ ed. Washington: OPAS/OMS/ILST; 1997. p.294-311.

Dallman PR. Developmental changes in red blood cell production and function. In: Rudolph AM, editor. Pediatrics. Norwalk: Appleton and Lange; 1991. p.1091-5.

Dallman PR. Diagnóstico laboratorial da deficiência de ferro no lactente e na criança pequena. In: Anais Nestle; 1996; 52:18-23.

Dallman PR. Iron deficiency and the immune response. Am $\mathbf{J}$ Clin Nutr. 1987; 46: 329-34.

De Maeyer EM. Preventing and controlling iron deficiency anemia through primary health care. Geneva: WHO; 1989.

Deandraca I et al. Phychomotor development and behavior in iron deficient anemic infants. Nutr Ver. 1977; 55: 125-32.

Devicenzi, MU, Ribeiro LC, Sigulem, DM. Suplementação de ferro na infância. Diagnóstico \& Tratamento. 1999; 4(1): 49-52.

Fisberg $M$ et al. Anemia and protein energy malnutrition among preschool children in São Paulo city, Brazil. In: Annals of the XXI International Congress of Pediatric; 1995 sep; Cairo.

Fisberg M, Braga JAP, Tadei JAA, Ferreira AMA, Kliamca PE, Schmidt, BJ. Utilização de suplemento alimentar enriquecido com ferro, na prevenção de anemia em pré-escolares. Pediatria Modema. 1996; XXXII(7): 753-8. 
Fisberg M, Braga JAP, Kliamca PE, Ferreira AMA, Berezowski M. Utilização de queijo petit suisse na prevençăo da anemia carencial em pré-escolares. Clin Pediatr. 2001; 6(19): 14-24.

Freire WB. Strategies of the PAHONHO for the control of iron deficiency in Latin America. Nutr Ver. 1972; 55:193-8.

Freire, W B. La anemia por deficiencia de hierro: estrategias de la OPS/OMS para combatirla. Salud Pública de México. 1998; 40 (2): 199-205.

Ghassemi H. Supplementary feeding in programmes in developing countries: lessons of the eighties - Part I: finding of the report. Asia Pacific J Clin Nutr. 1992; 1: 131-52.

Ghassemi $\mathrm{H}$. Supplementary feeding in programmes in developing countries: lessons of the eighties - Part II: discussions and references. Asia Pacific J Clin Nutr. 1992; 1: 195-206.

Gibson RS. Principles of nutrition assesment. New York: Oxford University Press; 1990.

Glassemi $H$ et al. Positive deviance in child nutrition: with emphasis on psychosocial and behavioural aspects and implications for development. In: United Nations University food and nutrition bulletin; 1990; Tokyo (Japan). Tokyo: United Nations University; 1990.

Guerra-Shinohara EM, Paiva RP, Santos HG, Sumita NM, Mendes ME, Nuñez LM et al. Determinação da ferritina sérica por dois métodos imunológicos automatizados. Rev Bras Anal Clin. 1998; 30(2):39-40.

Hadler MCCM, Juliano Y, Sigulem DM. Anemia do lactente. J Pediatr. 2002, 78(4): 321-6.

Hatska J, Lasserre JJ, SchWarzbeck A, Hehlmann R. Central role of zinc protoporphyrin in staging iron deficiency. Clin Chem. 1994; 40:768:73. 
Hatska J, Lasserre JJ, SchWarzbeck A, Reiter A, Hehlmann R. Laboratory tests of iron status: correlation or common sense? Clin Chem. 1996; 42:718:24.

Instituto Nacional de Alimentaçăo e Nutrição (INAN). Considerações sobre a anemia nutricional. Brasilia, INAN; 1986. 31p (mimeo).

International Nutritional Anemia Consultative Group (INACG). Measuraments of iron status. Washington (D.C.); 1985.

Johns WL, Lewis SM. Primary health screening byhaemoglobinometry in a tropical community. Bull. WHO 1989; 67:627-633.

Kim SK, Cheong WJ, Jun IH, Choi JW, Son BK. Red blood cells indices and iron status according to feeding practices in infants and young children. Acta Paediatr. 1996; 85:139-44.

Lerner A. \& lancu TC. Advances in understanding the bioavailability and absorption of iron. Front Gastrointest Res. 1988, 14:117-34.

Levy-Costa RB, Monteiro CA. Consumo de leite de vaca e anemia na infância no Municipio de São Paulo. Rev. Saúde Pública, 2004, 38 (6):30-7.

Levy-Costa RB. Consumo de leite de vaca e anemia na infância no Municipio de São Paulo. Săo Paulo; 2002. [Tese de doutorado - Faculdade de Saúde Pública].

Lima ACVMS, Lira PIC, Romani, SAM, Eickmann SH, Piscoya MD, Lima MC. Fatores determinantes dos niveis de hemoglobina em crianças aos 12 meses de vida na Zona da Mata Meridional de Pernambuco. Rev. Bras. Saúde Matern. Infant. 2004; 4(1): 35-43.

Mahan LK, Stump SE. Alimentaçăo, nutriçăo e dietoterapia. São Paulo: Roca; 1998. 
Male c, Persson LA, Freeman V, Guerra A, Van't Hof MA, Haschke F e Eurogrowth Iron Study Group. Prevalence of iron deficiency in 12-mo-old infants from 11 European areas and influence of dietary factors on iron status (Euro-Growth Study). Acta Paediatr. 2001; 90:492-8.

Marcondes E, organizador. Pediatria básica. $8^{\mathbf{a}}$ ed. São Paulo: Sarvier; 1992. v.1.

Martinez C, Ros G, Periago MJ, López G. Biodisponibilidad del hierro de los alimentos. Archivos Latinoamericanos de Nutricion. 1999, 49 (2): 106-12.

Massey AC. Microcity anemia. Differential diagnosis and management of iron deficiency anemia. Medical Clinics of North America. 1992, 76: 549-66.

Ministério da Saúde - Coordenação Técnica de Alimentação e nutrição. Projeto para controle da anemia ferropriva em crianças menores de 2 anos nos municipios do projeto de redução da mortalidade na infância. Brasilia (DF), MS. 5p (mimeo).

Monteiro CA, Szarfarc SC. Estudo das condições de saúde das crianças do Município de São Paulo - 1984-1985. Rev Saúde Pública. 1987; 21:255-60.

Monteiro CA. Saúde e Nutriçăo das crianças de São Paulo: Diagnóstico, Contrastes e Tendéncias. $1^{\text {a }}$ ed. São Paulo: HUCITEC; 1988.

Monteiro CA. Trajetória da saúde na cidade de São Paulo: mudança secular das estatísticas de jovens nascidos de 1950 - 1976. In: Congresso Brasileiro de Epidemiologia; 1998; Rio de Janeiro. Rio de Janeiro: ABRASCO; 1998.

Monteiro CA, Szarfarc SC, Mondini L. Tendência secular da anemia na infância na cidade de São Paulo (1984-1996). Rev Saúde Pública. 2000; 34(supl), 62-72. 
Monteiro CA. Evoluçăo da nutriçăo infantil nos anos 90. In: Monteiro CA, organizador. Velhos e novos males da saúde no Brasil: a evolução do país e suas doenças. $2^{\mathrm{a}}$ ed. Săo Paulo: Hucitec/Nupens/USP; 2000. p. 37592.

Monteiro CA, Szarfarc SC, Brunken GS, Gross R, Conde WL. A prescrição semanal de sulfato ferroso pode ser altamente efetiva para reduzir niveis endêmicos de anemia na infância. Rev. Bras. Epidemiol. 2002; 5:71-83.

Name JJ. Food fortification with amonoacid quelated. In: International Conference on human nutrition; 1995 Jan 21-22; Salt Lake City (Utah); 1995.

Neuman NA, Tanaka OY, Szarfarc SC, Guimarães PRV, Victora CG. Prevalência e fatores de risco para anemia no Sul do Brasil. Revista de Saúde Pública [Periódico on-line] 2000; 34 (1). Disponivel em URL:http://www.scielo.br [2004 junho 22].

Organizacion Mundial da La Salud. Anemias Nutricionales - Informe de um Grupo de Expertos de la OMS. Ginebra; 1972 (Organizacion Mundial de La Salud - Serie de Informes Técnicos; 503).

Oski FA, Honig AS. The effects of therapy on the developmental scores of iron-deficient anemia adolescents. Nutr. Rev. 1997; 55:125-32.

Oski FA, Naiman JL. Hematologia do recém-nascido. $3^{\mathrm{a}}$ ed. São Paulo: Manole; 1984.

Osório MM. Fatores determinantes da anemia em crianças. J Pediatr. 2002; 78(4): 269-78.

Paiva AA, Rondo PHC, Guerra-Shinohara EM. Paråmetros para avaliação do estado nutricional de ferro. Revista de Saúde Pública [Perídico on-line] 2000; 34 (4). Disponivel em URL:http://www.scielo.br [2004 abril 26]. 
Pineda O, Ashmed HDW. Effectiveness of treatment of iron-deficiency anemia in infants and young children with ferrous bis-glycinate chelate. Nutrition. 2001; 17:381-4.

Pineda $O$. Uso de ferro bisglicina quelato no tratamento da anemia ferropriva em crianças. Boletim CELANEM (Centro Latino Americano de Nutrição e Estudos Metabólicos. 2003; 1(1): 2-3.

Puffer RR, Serrano CV. Características del peso al nascer. Washington DC: OMS; 1988. (Publicación Científica, n.504).

Queiroz SS, Torres MAA. Anemia ferropriva na infância. J Pediatr. 2000; Supl. 3: 298-303.

Ribeiro LC, Devincenzi UM, Sigulem DM. Anemia ferropriva na primeira infância: controle e prevenção com doses intermitentes de ferro quelato glicinato. Compacta Nutrição. 2000.

São Paulo (Estado). Resolução da Secretaria de Agricultura e Abastecimento do Estado de São Paulo - SAA - 24, de 1 de agosto de 2000. Regulamenta o Projeto Estadual do Leite "VIVALEITE", estabelecendo as regras de credenciamento e de participaçăo de entidades da sociedade civil e de Prefeituras Municipais na sua execuçăo. Diário Oficial do Estado de São Paulo, Săo Paulo, 1 ago. 2000. Seção I.

São Paulo (Estado). Resolução de Estado da Saúde - SS - 489, de 6 de setembro de 1994. Aprova Norma Técnica que redefine critérios e beneficiários dos Programas de Suplementaçăo Alimentar nas Unidades Básicas de Saúde do Estado de São Paulo. Diário Oficial do Estado de São Paulo, São Paulo, 7 set. 1994. Seçăo I, p.27.

Såo Paulo (Estado). Resolução de Estado da Saúde - SS - 75, de 12 de março de 1991. Aprova critérios para inscrição e acompanhamento de crianças no Programa Integrado de Suplementação Alimentar - PISA. Diário Oficial do Estado de Såo Paulo, São Paulo, 13 abr. 1991. Seção I, p.34. 
Săo Paulo (Estado). Decreto n.37.736, de 27 de outubro de 1993. Cria o Conselho Estadual de Alimentação e dá providéncias correlatas. Diário Oficial do Estado de São Paulo, São Paulo, 27 out 1993.

Săo Paulo (Estado). Decreto n.37.739, de 27 de outubro de 1993. Institui o Programa "Săo Paulo Vidalimento - Leite" e dá providéncias correlatas. Diário Oficial do Estado de São Paulo, São Paulo, 27 out 1993.

São Paulo (Estado). Decreto n.40.036, de 5 de abril de 1995. Institui o "Programa Campo/Cidade - Leite", em substituição ao Programa "São Paulo Vidalimento - Leite" e estabelece diretrizes para sua execuçăo. Diário Oficial do Estado de São Paulo, Săo Paulo, 5 abr. 1995.

Săo Paulo (Estado). Decreto n.41.612, de 7 de março de 1997. Estabelece novas diretrizes para a execução do "Programa Campo/Cidade - Leite" e dá providéncias correlatas. Diário Oficial do Estado de São Paulo, São Paulo, 7 mar. 1997.

Săo Paulo (Estado). Decreto n.44.569, de 22 de dezembro de 1999. Institui o Projeto Estadual do Leite "VIVALEITE" dentro do Programa Estadual de Alimentação e Nutrição para populações carentes, em substituição ao Programa Campo/Cidade - Leite, de que trata o Decreto $n^{\circ} 41.612$, de 7 de março de 1997, e dá providéncias correlatas. Diário Oficial do Estado de Såo Paulo, Săo Paulo, 22 dez. 1999.

Såo Paulo (Estado). Processo ATL n.807, de 13 de maio de 1996. Encaminha indicação n.456, de 1996, da Comissão de Saúde e Higiene/Assembléia Legislativa do Estado. Informe. São Paulo, 5 mai. 1996.

Sichieri R, Szarfarc SC, Monteiro CA. Relação entre dieta e ocorrência de anemia ferropriva em crianças. J Pediatr 1988; 6:169-74. 
Silva DG, Franceschini SCC, Priori SE, Ribeiro SM, Szarfarc SC, Souza SB et al. Anemia ferropriva em crianças de 6 a 12 meses atendidas na rede pública de saúde do município de Viçosa, Minas Gerais. Rev Nutr. [Periódico on-line] 2002; 15 (3). Disponivel em URL:http://uww.scielo.br [2005 maio 9].

Soglia SLO, Abreu LR, Barcelos MFP. Aspectos tecnológicos e nutricionais da fortificação do leite com ferro. Higiene Alimentar. 2001, 15 (88): 50-55.

Soglia SLO, Abreu LR, Barcelos MFP. Enriquecimento de leite tipo C com ferro aminoácido quelato: biodisponibilidade e caracteristicas físicoquímicas e sensoriais. Viçosa; 1996. [Tese de mestrado da Universidade Federal de Viçosa].

Souza SB. Anemia e alimentação no primeiro ano de vida. São Paulo; 1994. [Tese de doutorado da Faculdade de Saúde Pública da USP].

Souza SB, Szarfarc SC, Souza JMP. Anemia no primeiro ano de vida em relaçåo ao aleitamento materno. Rev. Saúde Pública [Periódico on-line] 1997; 31 (1). Disponivel em URL:http://www.scielo.br [2005 junho 22].

Spinelli MGN, Souza SB. Consumo de alimentos fonte de ferro e de estimulantes de sua absorçăo por crianças menores de um ano. Ped Modema 2002; XXXVIII (4): 141-6.

Spinelli MGN. Concentraçăo de hemoglobina, prevalência de anemia e fatores de risco associados, em crianças brasileiras menores de um ano: um estudo multicêntrico de abrangência nacional. São Paulo; 2004. [Tese de doutorado - Faculdade de Saúde Pública da USP].

Spinelli MGN. Fatores de risco para anemia em crianças de 6 a 12 meses. Rev. Pan. Salud. Pública. 2005; 17 (2): 84 - 91.

Srikantia SG et al. Anemia and immune response. Lancet . 1976; 1307-9. 
Stefanini MLR, Lemer BR, Lei DLM, Chaves SP. Fome e Política: história, implantação, desenvolvimento, avaliação e implicações de um programa federal de suplementação alimentar do Estado de São Paulo. São Paulo: Instituto de Saúde; 1994.

Stekel A. Necessidades de hierro em el lactente y del nino. In: Resumo do IV Seminário Nestlé Nutrition - (El hierro em la alimentación del lactente y del nino); 1982 nov23-dez3; Manila (NY):Raven Press; 1984. p. 7-70.

Szarfarc SC et al Anemia control by the use of intermittent ferrous bisglycine incorprted in meals. Arch Latinoamericanos de Nutr. 2001 (remitted).

Szarfarc SC, Stefanini MLR, Lerner BR. Anemia Nutricional no Brasil. Cadernos de Nutrição. 1995; 9: 5-24.

Szarfarc SC, Berg G, Santos ALS, Souza SB, Monteiro CA. Prevenção de anemia no primeiro ano de vida em centros de saúde do município de Santo André, São Paulo. Jomal de Pediatria. 1996; 72(5): 329-34.

Taboada H. Rol de hierro em la nutrición infantil - primeira parte. Rev Chil Ped. 54:47-57, 1983.

Taboada H. Rol de hierro em la nutrición infantil - segunda parte. Rev Chil Ped. 54:47-57, 1983.

Taddei, JAAC. Avaliação antropométrica do impacto nutricional de um programa de suplementação alimentar. São Paulo; 1987. [Tese de doutorado - Faculdade de Saúde Pública].

Tomkins A, Watson FE. Malnutrition and Infection: a review. Geneve: WHO; 1999.

Torres MAA, Sato K, Queiroz SS. Anemia em crianças menores de dois anos atendidas em Unidades Básicas de Saúde no Estado de São Paulo, Brasil. Rev Saúde Pública. 1994; 28:290-94. 
Torres MAA, Sato K, Lobo NF, Queiroz SS. Efeito do uso de leite fortificado com ferro e vitamina $C$ sobre os niveis de hemoglobina e condição nutricional de crianças menores de dois anos. Rev Saúde Pública. 1995; 29:301-7.

Torres MAA, Sato K, Lobo NF, Queiroz SS. Fortificaçăo do leite fluido na prevenção e tratamento da anemia carencial ferropriva em crianças menores de 4 anos antes. Rev Saúde Pública. 1996; 30: 350-7.

Tudisco ES, Marin P, Shrimpton R, Costa M, Donohu E. Alimentação de desmame em áreas periurbanas em quatro capitais brasileiras. J Pediatr $1988 ; 64: 231-6$.

Turconi VL, Turconi SJ. Redução da anemia ferropriva em lactentes através de leite enriquecido. Pediatria Moderna. 1994; 30 (7): 1088-1094.

[UNICEF] Fundo das Naçőes Unidas para a infância. Situação Mundial da Infância. Brasilia - DF. 1993.

UNICEF/UNUMHO/MI. Technical workshop, 1998. Preventing iron deficiency in women and children: background and consensus on key technical issues and resources for advocacy, planning and implementing national programs. New York: 7-9 october, 1998.

UNICEF. Situaçăo Mundial da Infåncia. Brasilia, DF; 1998.

Valente, F. O combate à Fome e a desnutrição e a promoção da alimentação adequada no contexto do Direito Humano à Alimentação um eixo estratégico do desenvolvimento humano sustentável. São Paulo: Instituto da Cidadania, 2001.

Van Den Broek NR, Letsky EA, White AS, Shenkin A. Iron status in pregnant women: which measurements are valid? Br L Haematol. 1998; 103:817-24. 
Van Schenck $H$, Falkensson $M$, Lundberg B. Evaluation of "HemoCue", a new device for determining haemoglobin. Clin Chem. 1986; 32: 526-9.

Vannuchi $H$, Freitas MLS, Szarfarc, SC. A prevalência de anemias nutricionais no Brasil. Cademos de Nutrição. 1992; 4: 7-26.

Vianna GMC. Gonçalves AL. Comparação entre dois métodos de suplementação de ferro para a prevenção da anemia ferropriva no primeiro ano de vida em crianças nascidas prematuras. Jomal de Pediatria. 2002; 78(4): 215-20.

Viski MM. Política Pública de Suplementação Alimentar: Caracterização do Projeto Vivaleite no Municipio de Santo André - São Paulo. São Paulo; 2004. [Tese de mestrado da Faculdade de Saúde Pública da USP]

Vitolo, MR. Nutrição: da gestaçăo à adolescência. $1^{\text {a }}$ edição. Rio de Janeiro: Reichmann \& Affonso Editores Ltda, 2003. VI.

Walter T. Impact of iron deficiency on cognition in infancy and childhood. Eur J Clin Nutr. 1993; 47:307-16.

Walter T et al. Iron, anemia and infection. Nutr Rev. 1997; 58:111-24.

Walter T, Olivares M, Pizarro F, Muñoz C. Iron, anemia and infection. Nutr Rev. 1997; 55:111-24.

Weinber ED. Iron susceptibility to infection dieses. Science. 1974; 184: 952-6.

Wolde - Gebriel Z, West CE, Gebru H, Tadesse AS, Fisseha T, Gabre P et al. Interrelationship between vitamin $A$, iodine, and iron status in schoolchildren in Shoa region, Central Ethiopia. Br J Nutr. 1993; 70: 593607. 
World Health Organization. National strategies for overcoming micronutrient malnutrition. $89^{\text {th }}$ session of the executive board. Geneva; 1992.

Worwood M. Iron deficiency anaemia. In: Dacie SJV, Lewis SM, editors. Pratical haematology. Hong Kong: Churchill Livingstone; 1995. p. 437-44.

Yip R, Dallman PR. Hierro. In: Organización Panamericana de La Salud. International Life Sciences Institute. Conocimentos actuales sobre nutrición. $7^{\text {th }}$ ed. Washington (DC):OPS - Publicación Cientifica, 565; 1997.

*De acordo com as normas da Universidade de Săo Paulo. Faculdade de Saúde Pública. Biblioteca /CIR Guia de Apresentação de Teses. Cuenca AMB, Noronha DP, Ferraz MLEF, Andrade MTD de. São Paulo: A Biblioteca, 1998. 
ANEXOS 


\section{Anexo 1: Organização e Operacionalização do Projeto VIVALEITE}

\section{Operacionalizaçåo do Projeto - Capital e Região Metropolitana}

Na Capital e Região Metropolitana a inscrição das famílias, o controle da idade dos beneficiários e da respectiva renda familiar, bem como a distribuição do produto, são atividades efetuadas por entidades da sociedade civil sem fins lucrativos que, uma vez cadastradas, recebem o leite diretamente das usinas, das quais o produto é adquirido mediante licitação pública, modalidade pregão presencial, efetuada pelo Governo do Estado, por meio da CODEAGRO.

Todo o processo, desde a inscrição dos beneficiários até o repasse do produto, possui caráter filantrópico e voluntário, não havendo remuneração ou ajuda de custo de qualquer espécie para as atividades desenvolvidas pelos líderes comunitários, representantes de entidades cadastradas e municipios.

Da mesma forma, é expressamente vedado à entidade sob pena de descredenciamento, independentemente das sançōes penais cabiveis:

- cobrar contribuição de qualquer natureza para a inscrição das familias no Projeto ou para a entrega de leite;

- condicionar a participação da família no Projeto ao seu ingresso no quadro associativo da entidade ou ao pagamento de contribuição asssociativa;

- condicionar a distribuição do leite à aquisição, ou venda, pelas familias inscritas no Projeto, de bilhetes, bingos, rifas, sorteios, produtos ou à execução de qualquer atividade com o intuito de angariar receitas para a entidade;

- condicionar a inscrição da familia no Projeto à sua filiação ou participação político-partidária ou religiosa;

- descumprir exigência de ordem sanitária imposta pelo Poder Público;

- alterar o endereço de entrega do leite, sem prévia autorização da CODEAGRO. 


\section{a) Cadastramento das entidades}

A entidade que pleiteia ingresso no Projeto deve encaminhar ofício onde conste, necessariamente, os seguintes dados:

- Nome da associação;

- No de CNPJ da entidade;

- Endereço completo para correspondência (inclusive com CEP);

- Telefone para contato;

- Nome do presidente ou responsável.

É eventualmente convocada a associação em função das condiçōes de atendimento que apresentar, do relatório de atividades da entidade e, sobretudo, da localização de sua sede, a mais próxima da entidade descredenciada em caso de substituição desta, ou da comunidade onde se pretenda iniciar atendimento. Para seleção da entidade, é realizada visita por equipe técnica da CODEAGRO.

No ato de cadastramento, a entidade deve apresentar os seguintes documentos:

- estatuto social no qual conste, de forma explícita, a finalidade não lucrativa da instituição bem como, no caso de dissolução da mesma, o destino de seu patrimônio à outra entidade de fins congêneres (registrado em cartório);

- ata de eleição dos integrantes da diretoria em exercicio (registrada em cartório);

- inscrição no Cadastro Nacional de Pessoas Jurídicas (CNPJ);

- cédula de identidade e do cartão de identificação de contribuinte $(\mathrm{CIC})$ do presidente, seu substituto legal e da pessoa responsável pelo efetivo recebimento e distribuição do leite;

- relatório sucinto das atividades exercidas pela entidade.

\section{b) Prestação de contas}

As entidades da sociedade civil, mensalmente e em periodos préestabelecidos, comparecem na CODEAGRO ou a entidades sede, para efetuar a Prestação de Contas de sua atuação, apresentando as Fichas de Assinaturas, colhidas no mês precedente, atestando o recebimento mensal do produto por parte das mães beneficiárias, as vias de Nota Fiscal de recebimento do produto, as possíveis alteraçōes nos seus dados, bem como outros impressos que eventual 
e previamente venham a ser solicitados. Ainda, no ato da Prestaçāo de Contas são entregues as fichas de exclusão ou cadastramento de novas crianças no Projeto.

Tal material é recepcionado e conferido pela Equipe de Execução do Projeto. A equipe para recebimento da prestação de contas comparece mensalmente aos locais definidos, conforme cronograma pré-estabelecido, e conta com a colaboração de voluntários da comunidade, envolvidos com o Projeto, selecionados e treinados pela CODEAGRO.

\section{c) Cadastramento dos beneficiários}

As fichas de exclusão e cadastramento de crianças são entregues na prestação de contas e são enviadas, quinzenalmente, a uma empresa contratada, que as digita em um programa de gerenciamento de dados, por meio do qual os funcionários da CODEAGRO podem ter acesso e controlar todas as informaçōes das entidades.

Inscrição dos beneficiários: Para a obtenção do benefício a crianças na faixa etária preconizada, a familia deve apresentar junto à entidade:

1-Certidão de Nascimento da criança;

2-Documento de Identificação (RG) da mãe ou detentora da tutela/do idoso;

3-Carteira de Vacinação da criança ou do idoso;

4-Atestado de Residência (conta de luz);

5-Atestado de Rendimentos (hollerite);

Substituicaão de beneficiários: Procede-se à substituição de beneficiários, quando: - A criança inscrita completar 07 anos;

- Houver necessidade de atendimento aos critérios de prioridade e preferência;

- A renda familiar ultrapassar 02 salários mínimos;

- O beneficiário ou seu representante nāo comparecer nem justificar sua ausência por mais de 03 vezes no local e horário pré-estabelecido pela entidade para entrega do leite e assinatura da lista. 


\section{d) Orientação aos gestores do Projeto}

Ao ingressarem no VIVALEITE, as entidades assistenciais, por meio de seus presidentes e voluntários, participam de uma palestra, onde se elucida sobre toda a operacionalização do Projeto, incluindo critérios de inclusão e exclusão de beneficiários, documentação, direitos e deveres da entidade, do laticínio responsável pela entrega do leite, da CODEAGRO, da distribuidora de leite (em caso de haver uma) e dos beneficiários. A importância nutricional do leite e os cuidados necessários para seu consumo adequado só passaram a ser temas inerentes das palestras a partir do mês de junho de 2005.

\section{Operacionalizaçăo do Projeto - Municipios do interior do Estado}

A distribuição do leite no interior é efetuada por intermédio das Prefeituras Municipais, com base em convênios firmados entre a SAA e a Municipalidade, por meio dos quais são fornecidas cotas de leite de acordo com o percentual correspondente ao número de familias de baixa renda residentes no respectivo município. Após a celebração do convênio, o prefeito do município deve nomear uma instituiçăo para coordenar o Projeto (Secretaria de Agricultura, Secretaria de Saúde, Secretaria de Promoção e Assistência Social, etc), sendo que sua escolha não é influenciada pela SAA. Na instituição selecionada como coordenadora, será nomeada uma pessoa responsável pelo Projeto, a qual estabelecerá qualquer contato que se julgar necessário por ambas as partes envolvidas na execução do Projeto.

\section{a) Convênio com as prefeituras}

Para a celebração do convênio entre as prefeituras e a Secretaria de Agricultura, são solicitados tais documentos:

- declaração do exercício do mandato do prefeito;

- declaração de aplicação do mínimo constitucional na educação de $25 \%$;

- declaração do não impedimento de receber auxílios e subvenções pelo TCE;

- certidão negativa de débito junto ao INSS (atualizada); 
- lei municipal que autoriza a celebrar convênios com a Secretaria de Agricultura e Abastecimento do Estado de São Paulo;

- declaração de cumprimento da lei orgânica Municipal;

- comprovante de entrega de prestação de contas ao TCE;

- portaria ou decreto indicando membros para comporem a Comissão Municipal que supervisionará o Projeto;

- plano de trabalho.

O plano de trabalho deve conter:

- identificação do objeto a ser executado;

- quantidade de litros de leite a serem distribuidos mensalmente;

- especificação do(s) local (is) de distribuição;

- quantidade de beneficiários atendidos;

- forma de controle e avaliação do estado nutricional das crianças beneficiárias do Projeto, através da curva de crescimento da criança.

\section{b) Prestação de contas}

A prestação de contas dos municipios dá-se quinzenalmente e inclui as informaçōes: quantidade de litros de leite relativa à cota do municipio, quantidade de litros de leite recebida, e reiteração das condiçōes estabelecidas nos termos do convênio.

O envio das notas fiscais de recebimento do leite acontece semanalmente, sendo que as mesmas são recebidas e conferidas por equipe técnica do Projeto, que elabora cartas recibo, as quais são encaminhadas para o Centro de Finanças, a fim de se efetuar o pagamento dos laticínios.

\section{c) Cadastramento dos beneficiários}

O cadastramento das crianças nos municípios dá-se via on line, e a atualização dos cadastros e substituição das crianças são realizadas conforme necessidade do município. $O$ sistema é acompanhado e monitorado por equipe técnica do Projeto.

Os documentos requeridos para a obtençăo do benefício pela familia, bem como os critérios de substituição das mesmas são os mesmos da Capital. 


\section{d) Orientação aos gestores do Projeto}

As prefeituras participam de palestras realizadas nos municipios ou na SAA, todos os inícios de ano, por meio da presença do responsável pelo VIVALEITE, onde são abordados todos os aspectos relativos ao Projeto, incluindo a importância nutricional e os cuidados necessários para um consumo adequado do leite.

\section{Operacionalizaçăo do Projeto - Aspectos comuns à Capital, Região Metropolitana e Interior do Estado}

\section{Obrigações das partes envolvidas}

$>$ Obrigacões comuns (SAA e municípios)

1- Colaborar, acompanhar, supervisionar, avaliar e divulgar a implantação e o desenvolvimento das açōes decorrentes do convênio assinado entre a SAA e o municipio;

2- Fazer menção ao convênio sempre que for divulgado o andamento ou os resultados dos trabalhos nele previstos;

3- Assegurar o cumprimento dos termos e disposiçōes do Decreto $n^{\circ} 44.569$, de 22 de dezembro de 1999, e das normas estabelecidas por Resolução do Secretário de Agricultura e Abastecimento;

4- Assegurar o cumprimento dos termos e disposiçōes legais em vigor, atinentes à espécie, notadamente, a Lei Estadual $n^{\circ} 6.544$, de 22 de novembro de 1989 e a Lei Federal $n^{\circ} 8.666$, de 21 de junho de 1993, com as alterações posteriores;

5- Participar da Comissão Municipal responsável pela execução do Convênio, composta de 1 representante de cada partícipe e 1 representante do Conselho Municipal dos Direitos da Criança e do Adolescente. 


\section{Obrigaçōes da SAA com os municipios/entidades}

1- Entregar às entidades e municípios, por meio da empresa contratada como fornecedora do produto na região, a cota de leite pré-estabelecida ( 3 vezes por semana no interior e 2 vezes por semana na Capital e Região Metropolitana);

2- Proceder à fiscalização e supervisão do fornecimento do leite, através da Coordenadoria de Abastecimento, conforme os termos do convênio e o contrato, assinado entre a SAA e a empresa fornecedora;

3- Proceder à avaliação periódica do convênio (nos Municípios).

\section{Obrigaçōes das entidades com a SAA (Termo de Responsabilidade)}

1-Repassar o produto aos beneficiários de forma inteiramente gratuita, sem imposições ou condicionamentos de qualquer espécie;

2-Preencher as fichas de cadastro das familias a serem atendidas pelo Projeto e verificar o cumprimento dos requisitos estabelecidos para este fim; 3-Divulgar junto à comunidade as condiçōes para percepção dos benefícios do Projeto e os critérios para sua inserção;

4-Manter atualizado o cadastro das familias;

5-Distribuir aos beneficiários do Projeto (2 vezes por semana), os 15 litros de leite/mês, mediante assinatura mensal dos mesmos, atestando 0 recebimento do benefício;

6-Providenciar a exclusão das famílias que descumpram as condições para permanência no Projeto, ou seja, aquelas cuja renda mensal passar a ser superior a 2 salários-mínimos, cujos filhos completarem 7 anos ou que faltarem por 3 vezes consecutivas na assinatura da lista de presença;

7-Comunicar mensalmente à CODEAGRO as alteraçōes no cadastro das famílias;

8-Encaminhar à CODEAGRO, periodicamente e em datas préestabelecidas, os formulários contendo as assinaturas dos beneficiários, atestando o recebimento do produto, bem como discriminando dados das notas fiscais recebidas (número, quantidade de litros e data) - prestação de contas; 
9-Informar à CODEAGRO as irregularidades constatadas quanto à qualidade e quantidade do leite, bem como em relaçăo à embalagem; 10-Acompanhar o cumprimento das obrigaçōes estabelecidas para a permanência dos beneficiários no Projeto;

11-Informar à CODEAGRO as alteraçōes de seu estatuto social ou na composição de sua diretoria, no prazo máximo de 30 dias da ocorrência;

12-Informar à CODEAGRO, necessariamente com antecedência de 10 dias, eventual alteração no endereço de distribuição do leite;

13-Informar aos beneficiários o nome completo da entidade social e o número de credenciamento junto à CODEAGRO;

14-Participar de reuniōes de orientação, quando convocada;

15-Prestar à CODEAGRO, quando solicitadas, informações e esclarecimentos acerca do andamento dos trabalhos.

\section{Obrigaçōes dos municípios com a SAA}

1- Realizar o cadastramento das crianças a serem beneficiadas pelo Programa, residentes no território municipal, que preencham as condições estabelecidas no Decreto;

2- Efetuar o controle mensal das crianças beneficiárias, atualizando o cadastro quanto ao rendimento familiar e à idade das crianças e zelando pela destinação do reforço nutricional;

3- Definir o órgão do Município que responderá pelo Projeto, e indicar, por escrito, o seu responsável e os locais adequados para a sua instalação e funcionamento;

4- Distribuir às crianças beneficiárias (3 vezes na semana), a cota de 15 litros de leite/mês (podendo ser cadastradas até 2 crianças por família);

5- Permitir a verificaçăo, pela SAA, de toda a operação de distribuiçăo, bem como das fichas cadastrais e documentos comprobatórios;

6- Afixar nos locais de cadastramento e distribuição, a lista dos beneficiários, os critérios e horários estabelecidos para a entrega do leite;

7- Apresentar relatório mensal sobre o desenvolvimento do Programa, conforme modelo instituído pela Coordenadoria de Abastecimento. 


\section{$>$ Obrigaçōes das entidades/municipios com o laticinio}

1- Receber o leite por meio de um representante designado para tal fim, que verificará as condições da mercadoria e de seu armazenamento;

2- Preencher o carimbo no corpo da nota fiscal, com o nome do municipio/entidade, nome e $n^{\circ}$ da cédula de identidade (RG) do responsável pelo recebimento, data e assinatura;

3- Entregar a $1^{\mathbf{a}}$ via da nota fiscal devidamente preenchida para a empresa, no dia do recebimento do leite;

4- Enviar cronograma para a empresa, contendo: locais de distribuição, quantidade e horário.

O representante da entidade ou prefeitura deve ser orientado a manter contato com o laticínio para informar-se das causas de eventuais ocorrências de atrasos na entrega que podem ocorrer por diversos motivos (trânsito, acidentes, enchentes, etc.), bem como para verificar as entregas em feriados, agendando a reposição do produto.

Obrigacões do laticínio com as entidades/municipios

1- Fornecer leite pasteurizado, com teor de gordura mínimo de $3 \%$ (três por cento), enriquecido com 7,5mg de ferro (aminoácido quelato), 2000Ul de Vitamina A e 400UI de Vitamina D por litro;

2- Embalar o leite em sacos plásticos de 1 (um) litro, padronizados, com 0 logotipo do Projeto, dados da empresa fornecedora, indicações técnicas e data de validade;

3- Entregar o leite, no prazo máximo de 1 (um) dia após a data de fabricação, em temperatura inferior a $7^{\circ} \mathrm{C}$ (sete graus Celsius);

4- Fornecer recipientes isotérmicos (caixa de isopor) para manutenção do produto na mesma temperatura da entrega, em quantidade suficiente para - acondicionamento da quantidade total recebida no dia, nos locais de distribuiçăo;

5- Entregar o leite no mínimo duas (2) vezes na semana nas três primeiras semanas e uma (1) vez na quarta semana, nas entidades; e no mínimo três 
(3) vezes na semana, perfazendo doze (12) entregas no mês, nos municipios;

6- Entregar o leite em locais pré-determinados pelas prefeituras e entidades, de acordo com o cronograma mensal acertado entre o licitante $e$ as entidades ou municípios, sendo que o horário de entrega deve ser das $6 \mathrm{~h}$ às $12 h$, por determinação da SAA;

7- Possuir caminhão de entrega do leite com certificado de vistoria, de acordo com o código sanitário vigente, conforme especifica a Portaria CVS-15, de 07/11/91, e demais alteraçōes introduzidas pela Portaria CVS-16, de 24/10/2004;

8- Substituir, de imediato ou no prazo de 24 horas, em caso de embalagem danificada ou furada, a quantidade de leite necessária.

\section{$>$ Obrigacões dos beneficiários}

- Crianças:

1-apresentar identificação do responsável legal;

2-apresentar certidão de nascimento e carteira de vacinação da criança;

3-apresentar comprovante de renda familiar e, quando necessário, da condição de desemprego ou de ser a mãe arrimo de família.

- Idosos:

1-apresentar o documento de identidade;

2-apresentar carteira de vacinação;

3-apresentar prova de rendimento familiar e, quando for o caso, atestado médico de ser portador de doença crônica com necessidade de uso constante de medicamentos.

\section{Controle de Qualidade}

Orientaçōes sobre problemas operacionais especificos das entidades relacionados a atrasos na entrega do leite, inadequaçōes relativas à qualidade ou distribuição do mesmo, esclarecimentos e informaçōes diversas a mães inscritas, 
entidades e representantes das Prefeituras são realizadas por meio do sistema 0800.

As denúncias de atuação irregular por parte dos municipios e entidades cadastradas no Projeto (imposição de taxas às famílias inscritas, inobservância dos critérios de renda ou idade de beneficiários, etc.) recebidas pelo sistema 0800 , são apuradas por meio de Vistorias que poderão resultar, caso comprovada a procedência, em advertência sob a forma de convocação de representantes para assinatura de Termo de Compromisso, ou no descredenciamento, com conseqüente remanejamento dos beneficiários inscritos para outra instituição.

Até o ano de 1999, a coleta de amostras de leite para análise era realizada, apenas, mediante denúncias de irregularidades relativas à qualidade do produto.

A partir de abril de 1999, iniciou-se a coleta sistemática de amostras e o seu envio ao Instituto de Tecnologia de Alimentos (ITAL), para análise. Inicialmente, esse sistema restringiu-se aos municipios do interior do Estado de São Paulo, passando à Capital e Grande Săo Paulo após ajustes necessários.

Assim, para garantir a boa qualidade do produto, a CODEAGRO passou constantemente a coletar amostras e a enviá-las ao Instituto Adolfo Lutz (IAL) e ao Instituto de Tecnologia de Alimentos (ITAL), para análises físico-químicas, microbiológicas e análises especiais (vitamina A e ferro), em todo o Estado.

O número de amostras era relativo ao contrato, sendo coletada uma amostra para cada cem mil litros de leite distribuídos pelas Usinas, totalizando seis (6) litros por amostra. No entanto, sendo constatadas irregularidades, ou mesmo em casos de denúncia, reservava-se o direito de coletar nova amostra.

O cronograma de coleta assegurava que todas as Usinas tivessem amostras analisadas pelo menos uma vez durante a vigência do contrato. As amostras da Capital e Grande São Paulo eram retiradas diretamente do ponto de distribuição por uma equipe de técnicos da CODEAGRO, sendo encaminhadas para o Instituto Adolfo Lutz (IAL). No tocante ao Interior do Estado de São Paulo, as amostras eram coletadas e enviadas diretamente ao Instituto de Tecnologia de Alimentos (ITAL), pela Prefeitura, previamente informada das datas, através de ofício emitido pela CODEAGRO. No referido ofício, constavam as instruções, as 
quais eram válidas, também, para a coleta de amostras da Capital e Grande São Paulo:

- referente à coleta: cada amostra deve ser composta por seis (6) embalagens de um (1) litro de leite cada, do mesmo lote de fabricação, que estejam dentro do prazo de validade e cuja temperatura não seja superior a $10^{\circ} \mathrm{C}$. As amostras não devem ser congeladas.

- referente ao transporte: as amostras devem ser transportadas em embalagens térmicas, com gelo, de tal forma que, durante o percurso fique assegurado que a temperatura do leite não ultrapasse os $10^{\circ} \mathrm{C}$ e que não haja danos na embalagem.

Em casos de irregularidades na análise, as providências tomadas consistiam em: advertência por escrito ao fornecedor, comunicação à prefeitura e solicitação de envio de nova amostra para análise. Caso o novo resultado indicasse um produto irregular, iniciavam-se as medidas legais cabiveis, solicitando-se, inclusive, a ação da Vigilância Sanitária.

No ano de 2005, foi elaborado um novo sistema para o controle de qualidade do leite, o qual foi aprovado e concretizado, mediante a criação de uma nova equipe de organização de trabalho (Monitoramento da Qualidade do Leite) composta por médicos veterinários, oficial administrativo e estagiários. $O$ objetivo do novo sistema é prevenir a ocorrência de uma nāo-conformidade, garantindo aos beneficiários a qualidade higiênico-sanitária e nutricional do leite consumido.

Assim, estabeleceu-se uma parceria entre a CODEAGRO e a Coordenadoria de Defesa Agropecuária (CDA), no intuito de garantir uma maior rigidez no controle de qualidade do leite, já que a CDA tem aval legislativo para apreender lotes de leite inadequados. Essa parceria somente é executada para o monitoramento nos municipios do interior do Estado de São Paulo.

O novo procedimento operacional de controle de qualidade do leite nos municípios do interior do Estado de Sāo Paulo consiste em:

- Programação: realizada pela CDA - consiste em elaboração de cronograma de fiscalização e coleta, por empresa, por semana, levando-se em conta a vigência do contrato (entre o laticínio e a CODEAGRO -SAA) e a cota mensal distribuida pelo laticinio (deve-se realizar 1 análise a cada 100.000 litros 
de leite distribuídos, por laticinio). $\mathrm{O}$ referido cronograma deve ser enviado ao ITAL e à CODEAGRO;

- Fiscalização e coleta de amostras: realizada pela CDA - consiste em aplicação de "Termo de Fiscalizaçāo Volante", que objetiva avaliar as condições gerais de distribuição do leite. Após a aplicação do termo pelo responsável técnico da CDA, procede-se à coleta e a liberação do produto para distribuição às familias. Caso se verifique irregularidade relativa à temperatura do leite, a coleta e a liberação para distribuição às familias são impedidas.

- Análise e laudo: realizados pelo ITAL - consiste em realização de análises físico-químicas, microbiológicas, de Vitamina $A$ e de Ferro e envio de laudo à CODEAGRO, para tomada das devidas providencias. Posteriormente, e com o respectivo pagamento da análise por parte do laticínio, envio do laudo para 0 mesmo.

O novo procedimento operacional de controle de qualidade do leite na Capital e Grande São Paulo consiste em:

- Programação: realizada pela CODEAGRO - consiste em elaboração de cronograma de coleta, por empresa, por semana, levando-se em conta a vigência do contrato (entre o laticinio e a Secretaria de Agricultura) e a cota mensal de leite entregue pelo laticinio. $O$ referido cronograma deve ser enviado ao IAL. Os funcionários da CODEAGRO são os responsáveis pela verificação da temperatura do leite, coleta de amostras e encaminhamento das mesmas ao IAL;

- Análise e laudo: realizados pelo IAL - consiste em execução de análises físico-químicas, microbiológicas, de Vitamina $A$ e de Ferro e envio de laudo à CODEAGRO, para tomada das devidas providências. Posteriormente e com o respectivo pagamento da análise por parte do laticínio, envio do laudo para 0 mesmo.

A coleta de amostras deve obedecer aos seguintes procedimentos:

- o leite deve ser coletado no caminhão, antes de ser descarregado no local de distribuição;

- deve ser coletada uma (1) amostra, constituida por seis (6) embalagens de um (1) litro de leite; 
- deve-se aferir a temperatura do caminhão e do leite;

- as amostras devem ser transportadas em embalagens térmicas, com gelo, não devendo ser congeladas;

- os horários de coleta são baseados nos horários de entrega do leite nos municípios/entidades;

- as amostras devem ser transportadas de tal forma que, durante o percurso fique assegurada a integridade das mesmas, evitando-se o aumento da temperatura e danos na embalagem;

- no momento da entrega das amostras de leite no laboratório são devidamente preenchidas e protocoladas três (3) vias de solicitação de análise, das quais uma cópia permanece no laboratório, uma cópia é arquivada na CDA e outra cópia é enviada à CODEAGRO - somente para as amostras coletadas nos municipios;

- no momento da entrega das amostras de leite no laboratório são devidamente preenchidas e protocoladas duas (2) vias de solicitação de análise emitidas pela CODEAGRO, das quais uma cópia permanece no laboratório, e outra retorna à CODEAGRO - somente para as amostras coletadas na Capital e Grande São Paulo.

As características observadas na distribuição/ ponto de entrega são:

- temperatura;

- embalagem e rotulagem;

- data de validade;

- higiene do caminhão e das caixas de isopor;

- quantidade de leite entregue;

- condiçōes do local de entrega;

- condições do transporte;

- reposição do leite;

- fornecimento e reposição das caixas de isopor;

- cumprimento do cronograma elou horários de entrega;

- volume de leite da embalagem. 
Em casos de constatação de irregularidades observadas nos laudos de análise do leite ou em decorrência do monitoramento, procede-se à notificação do laticinio, mediante assinatura de Termo de Ciência. Caso haja reincidência de irregularidade, procede-se à aplicação de multa (com publicação no Diário Oficial), e posterior descredenciamento do laticínio do Projeto, seguido de impedimento de participação em processo licitatório do Estado de São Paulo, por um período de até cinco (5) anos.

Mediante reclamaçōes ou denúncias advindas do serviço de 0800 , de e.mails ou contatos telefônicos diretos, procede-se:

- contato telefônico com o laticínio, relatando o problema e definindo um prazo para sua solução;

- visita técnica ao local responsável pela reclamação/denúncia, para verificação do problema e definição de ação corretiva.

\section{Adiçáo do mix de vitaminas}

Não consta de nenhum documento da SAA (Decreto, Resolução, Contrato com os laticínios) um procedimento padrão de adição do mix de vitaminas ao leite do Projeto VIVALEITE. Assim, o laticinio ao adquirir o produto da empresa, adiciona-o ao leite de acordo com suas próprias determinaçōes ou, ainda, mediante instruções do fabricante.

\section{Contratação do Beneficio}

A compra do leite distribuido é realizada por meio de processo licitatório e segue a modalidade "Pregão Presencial", onde o laticínio que dispor do menor preço, desde que atendidas as normas do Projeto, será declarado vencedor. São realizadas duas licitaçōes distintas, uma para os 606 municipios do interior do Estado de São Paulo, compreendendo 59 blocos de atendimento, e outra para a Capital e municípios da Grande São Paulo, compreendendo 9 blocos de atendimento. 


\section{Metas}

Implantar, para todo o Estado, o sistema de cadastramento de beneficiários via on line e disponibilizar a complementação do mesmo com os dados referentes ao acompanhamento nutricional das crianças.

Implementar as ações de desenvolvimento comunitário e resgate da cidadania por meio da difusão dos serviços prestados pelo Estado (obtenção de documentação básica, localização e condiçōes de acesso a serviços de saúde, educação, segurança, etc.) e incremento da cidadania por meio de ações de geração de renda, erradicação do analfabetismo, combate à evasão escolar, campanhas de saúde preventivas junto a crianças e mulheres de baixa renda, combate à desnutrição e ao trabalho infantil, por intermédio de ações conjuntas com outras Secretarias e Orgãos Públicos Municipais.

\section{Abrangência}

Para o atendimento da população beneficiada, participam cerca de 4.700 entidades da sociedade civil sem fins lucrativos na Capital e Região Metropolitana e 606 municípios do interior do Estado, o que se traduz em atendimento a 720.000 beneficiários, sendo 40.000 idosos e 680.000 , para os quais são distribuídos cerca de 11.000.000 litros de leite, por mês.

\section{Recursos}

Os recursos destinados à compra do leite distribuído são de $R \$ 10.805 .227,20$ mensais, ou aproximadamente $R \$ 130.000 .000,00$ por ano. Esses valores são aproximados, dado que o preço do leite varia de acordo com os blocos de atendimento em que são divididos os municípios do interior do Estado, a Capital e a Regiāo Metropolitana. O orçamento é baseado em uma previsão (estudo) do preço médio do litro do leite. O preço médio do litro do leite adquirido na última licitação (janeiro de 2005) foi de $R \$ 1,01$ para os blocos da Capital e Regiäo Metropolitana e de R\$1,05 para os blocos dos municípios do interior do Estado. 
UNIVERSIDADE DE SÃO PAULO/FACULDADE DE SAÚDE PÚBLICA DEPARTAMENTO DE NUTRIÇÃO

Av. Dr. Arnaldo, 715 - Cerqueira Cesar CEP: 01246-904 São Paulo/SP

Tel./FAX: (011) 3066-7705/ 7771/7762

Tel.: (011) 3062.6748

e-mail:hnt@fsp.usp.br

\section{Termo de Consentimento Livre e Esclarecido}

Fui informada(o) sobre a pesquisa "Concentração de hemoglobina em crianças antes e depois de sua inscriçăo no Projeto Estadual do leite - Vivaleite", cuja responsabilidade é de Ana Carolina Enciso de Sá, aluna do curso de mestrado da Faculdade de Saúde Pública da Universidade de São Paulo, em projeto conjunto com a Secretaria de Agricultura e Abastecimento do Estado de São Paulo.

A anemia ferropriva é uma doença que ocorre pela falta de ferro no organismo. A criança anêmica pode apresentar os seguintes sintomas: fraqueza, palidez, menor capacidade de resistir às infecções, menor capacidade de aprendizado e atenção. As crianças que tem entre 6 meses e 2 anos de idade correm um grande risco de se tornarem anêmicas.

O objetivo da presente pesquisa é observar se o leite doado pelo Projeto Vivaleite é eficaz no sentido de colaborar com uma melhora no estado nutricional de ferro da criança beneficiada.

Em caso de a criança encontrar-se anèmica, esta receberá um Termo de Encaminhamento, com o resultado do teste de hemoglobina e a recomendação de tratamento em um posto de saúde.

Caso eu concorde em participar da pesquisa, responderei a um questionário de aproximadamente dez minutos de duração e disponibilizarei meu filho(a) para a realização de exame que consiste em coleta de uma gota de sangue para medir concentração de hemoglobina realizado com material descartável, e que não implica em nenhum prejuízo para a criança.

O exame a ser realizado tem o intuito de verificar se a criança encontra-se ou não anêmica(o).

Jamais terei meu nome mencionado na ocasião da apresentação dos resultados e não receberei nenhum pagamento pela minha participação.

Estou ciente de que, se, por algum motivo, não queira participar da pesquisa, o leite me será entregue normalmente.

Se eu concordar em participar da pesquisa, será pedido que eu assine o Termo de Consentimento Livre e Esclarecido. Caso eu não assine, minha decisão será plenamente respeitada, e tal fato não me impedirá de participar da pesquisa.

Depois de leitura completa e conjunta, minha e da pesquisadora responsável, deste Termo de Consentimento, decidi por participar da pesquisa, de modo livre e esclarecido.

Assinatura da participante:

Assinatura da pesquisadora:

Pesquisadora: Ana Carolina Enciso de Sá

Endereço: Rua Professor Machado Tolosa, 148, Mooca - Sāo Paulo - SP, Tel: 66950299

São Paulo,

de 2003. 
Anexo 3: Questionário para as mães ou responsáveis

Nome do municipio

Data:

12003.

Nome da criança

Nome

( ) mãe ou pai ( ) outros

CARACTERISTICAS DA CRIANÇA

[ $\mathrm{Hb}$ ] g/dl

Nascimento: Peso ao nascer: 9 Prematuro ( ) S ( ) N Tempo de VIVALEITE meses Tempo de amamentação: dias meses

Quem cuida da criança: ( ) mãe ( ) pai ( ) avós ( ) creche ( ) outros

Toma outro leite? ( ) Sim （）Não Qual?

Quanto? Mam./dia Copos/dia ( ) X/Sem. Obs

Consumo VIVALEITE ( )Puro Com água $\mathrm{ml}$ Com café $\mathrm{ml}$ Outros

Ferve o leite? ( )S ( )N Despreza a nata? ( )S ( )N Usou recentemente sulf. ferroso? ( )S ( )N Oferece carne? ( ) X/dia e ( ) X/semana Obs:

Oferece feijão? ( ) X/dia e ( ) X/semana Obs:

Encontra-se doente? ( ) Sim ( ) Nāo Qual?

\section{CARACTERISTICAS FAMILIARES}

Contribuem para o sutento familiar: ( ) mãe ( ) pai ( ) outros

Escolaridade materna: ( ) analfabeta

10 grau

20 grau

Escolaridade paterna: ( ) analfabeta 10 grau 20 grau

No moradores: No filhos vivos:

Renda familiar: $\mathbf{R} \boldsymbol{\$}$

Estado civil: ( ) Solt. ( ) Cas. ( ) Amas. ( ) Outros Armazena o leite na geladeria? ( ) S ( ) N Recebe alimentos de outros programas: ( )S ( )N Qual?

\section{QUANTIDADE PER CAPITA DO LEITE DO VIVALEITE}

\begin{tabular}{|l|l|l|l|l|l|l|}
\hline Parentesco em relação à mãe & $\begin{array}{l}\text { Idade } \\
\text { (anos) }\end{array}$ & Quant./ dia & Unidade * & $\begin{array}{l}\text { Todos } \\
\text { os dias }\end{array}$ & $\begin{array}{l}\text { Freq. } \\
\text { Semanal }\end{array}$ & Nunca \\
\hline Filho beneficiado & & & & & & \\
\hline A própria & & & & & & \\
\hline & & & & & & \\
\hline & & & & & & \\
\hline & & & & & & \\
\hline
\end{tabular}

Unidade *MM = mamadeira média $(240 \mathrm{ml}) ; \mathrm{MP}=$ mamadeira pequena $(150 \mathrm{ml}) ; \mathrm{CR}=$ copo de requeijão $(240 \mathrm{ml}) ; \mathrm{CA}=$ copo americano $(150 \mathrm{ml})$.

Responsável pela coleta das informaçóes: 


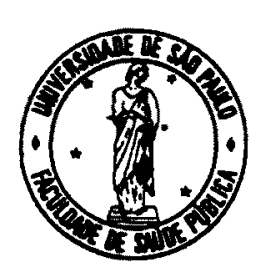

UNIVERSIDADE DE SÃO PAULO/FACULDADE DE SAÚDE PÚBLICA

DEPARTAMENTO DE NUTRIÇÃO

Av. Dr. Arnaldo, 715 - Cerqueira Cesar

CEP: 01246-904 São Paulo/SP

Tel./FAX: (011) 3066-7705/7771/7762

Tel.: (011) 3062.6748

e-mail:hnt@fsp.usp.br

Venho por meio deste, informar que no dia / 2003, a criança

realizou exame de dosagem de hemoglobina, por meio de punção de uma gota de sangue, mensurada no aparelho Hemocue ${ }^{\circledast}$. Este exame foi realizado por nutricionistas da Faculdade de Saúde Pública Universidade de São Paulo, para a pesquisa “Concentração dos níveis de hemoglobina em crianças de 6 a 36 meses, antes e depois de sua inscrição no Projeto Estadual do Leite - VIVALEITE”.

$O$ nível de hemoglobina encontrado foi de $\mathrm{mg} / \mathrm{dl}$, estando dentro dos padrões de normalidade para a idade / sendo necessário acompanhamento médico. Recomenda-se que o responsável procure um posto de saúde para tratamento adequado. 
Anexo 5: Orientação Nutricional

\section{Orientacão mutricional}

Definição, causas e conseqüências da anemia ferropriva:

A anemia ferropriva é uma doença causada pela falta de ferro no organismo, ou seja, pelo baixo consumo de alimentos fonte de ferro. As crianças menores de 2 anos são as mais susceptiveis pelo rápido crscimento, que demanda maiores quantidades de ferro.

As consequências são fraqueza, apatia, dificuldades no aprendizado, menor vontade de brincar, facilidade em contrair doenças

\section{> Alimentaçåo:}

- Incentivo ao consumo de carnes e visceras (principalmente o fígado) pelas crianças, explanando que são os alimentos que mais contêm ferro, mineral essencial para o não desenvolvimento da anemia ferropriva;

- Incentivo ao consumo de feijão, explanando que, dentre os alimentos de origem vegetal, este é o que mais contém ferro;

- Incentivo ao consumo de alimentos ou sucos citricos durante ou após as refeições principais, elucidando que seriam facilitadores da absorção do ferro de origem vegetal. 


\section{Leite distribuído pelo Projeto VIVALEITE:}

- Não ferver - a fervura pode ocasionar perda de ferro pela adesão deste à nata formada e normalmente descartada após este processo (NAME 1995; TORRES et al. 1996), bem como promover perdas de vitamina A, a qual se degrada em decorrência de temperaturas elevadas;

- Não descartar a nata, em casos de necessidade de fervura do leite (ausência de geladeira ou aceitabilidade por parte da criança), fazendo com que a criança a consuma;

- Agitar o saquinho de leite - para misturar o conteúdo da embalagem à gordura aderida às bordas do saquinho, no sentido de evitar as possiveis perdas de ferro pela adesão deste à gordura;

- Lavar a embalagem;

- Não diluir o leite com água;

- Priorizar a criança mais nova, no consumo do leite em casa, - a fim de estender ao domicílio a prioridade já existente no Projeto (crianças de 6 meses a 2 anos de idade). 
Anexo 6: Folder sobre o Projeto VIVALEITE

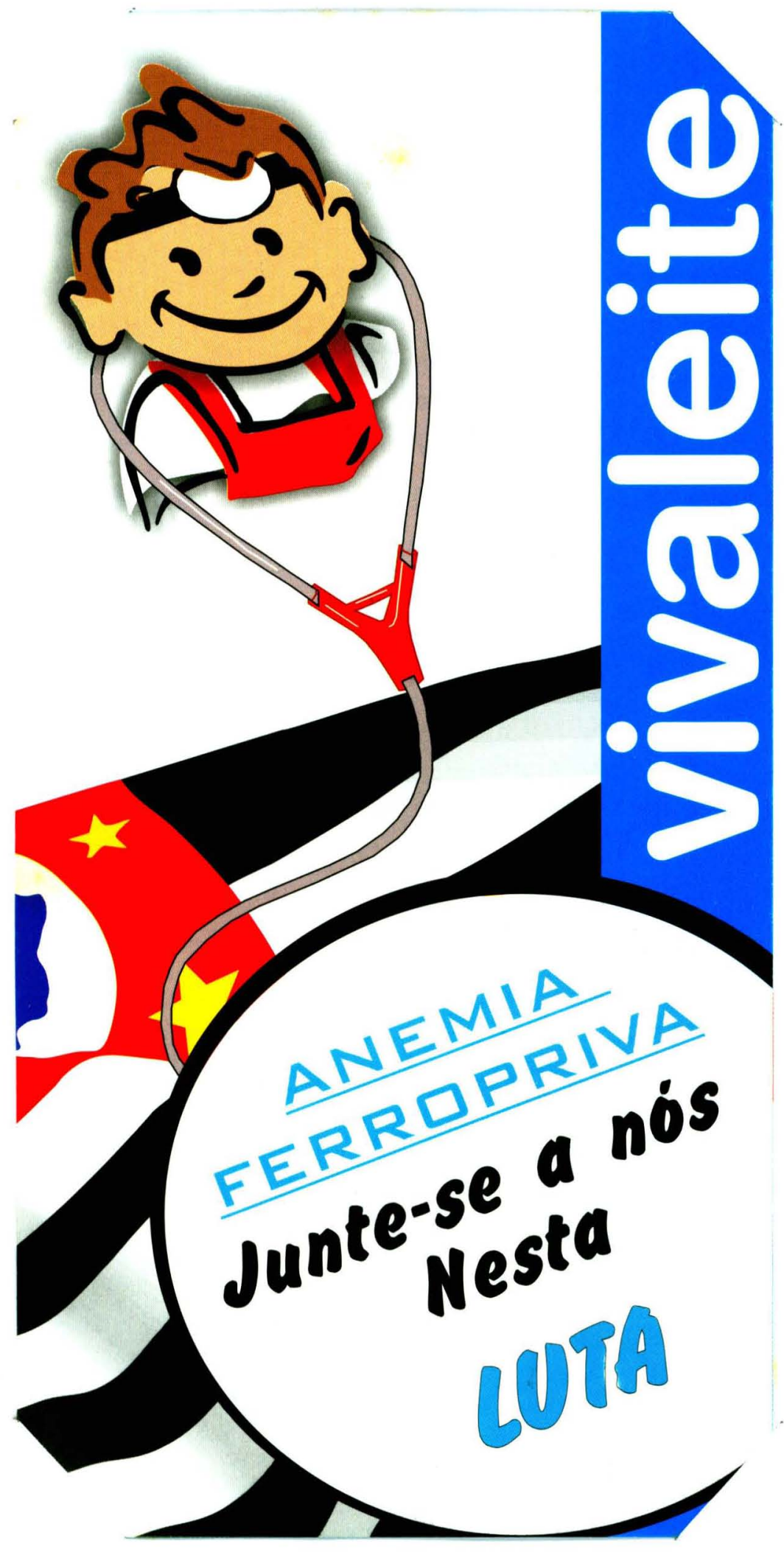




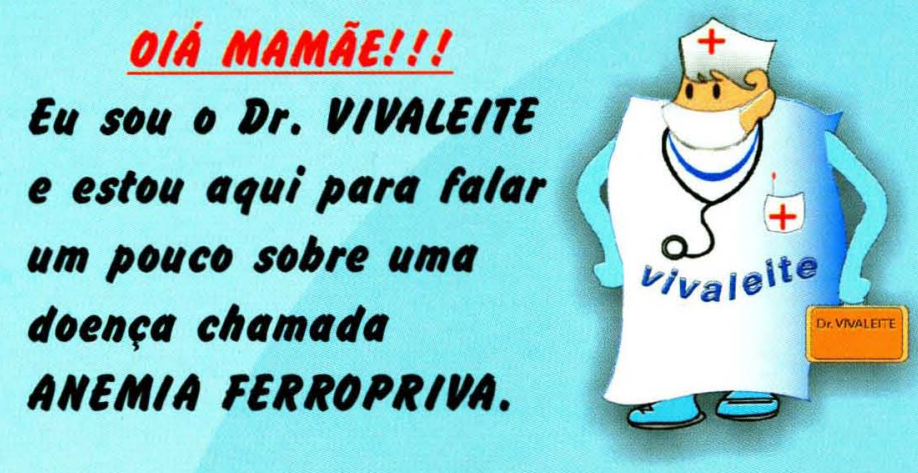

VOCÊ SABE O QUE É ANEMIA FERROPRIVA?

A ANEMIA FERROPRIVA é uma doença causada pela falta de ferro no organismo que deixa a criança fraca, apática, descorada, com menos vontade de brincar e racilmente doente. Ela areta principalmente as crianças menores de 2 anos.

\section{SABE POR QUE?}

Porque nesta idade 16 meses a 2 anos) o seu Mtho esth passando por uma rase de crescimento rápido, o que aumenta a necessidade de ferro.

Outros motivos saio: a alimentaçäo que pode estar inadequada em quantidade - qualidade, presença de verminoses doenças intestinais.
Foi por isso que, pensando na saúde de seu rilho, - Governo do Estado de Säo Paulo resolven travar uma luta contra essa doença. Para isso, distribui gratuitamente leite enriquecido com Ferro e vitaminas A e $D$, através do Projeto Estadual do Leite. VIVALEITE.

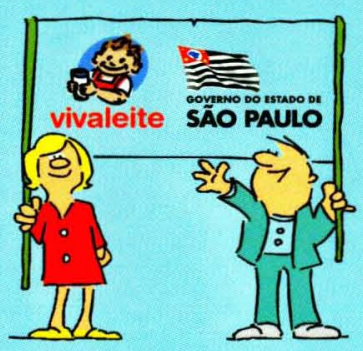

Mäe, vocé rambém pode ajudar seu milho na luta contra essa doença!

Sabe como?

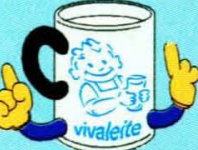

Certifique-se que sen filho menor

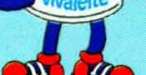
de 2 anos está tomando todo o leite recebido.

sempre que puder, indura nas refeiçóes do seu Bllho, alimentos que contenham rerro, tais como:

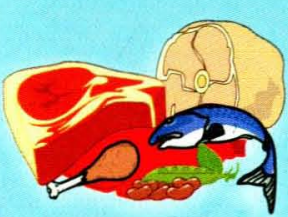

Figado, carnes em geral (bovina, aves e peixes) $e$ reijão.

Procure servir, após as refeiçóes, sucos ou frutas ricas em vitamina C, como laranja, mexirica, limäo e abacaxi ( a vitamina $C$ aumenta o aproveitamento de rerro pelo organismo).
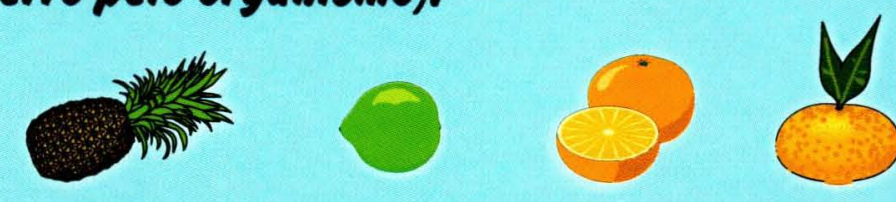

Orereça para o seu fillho somente o leite materno até os 6 meses de idade, pois ele é - mellior alimento nesta fase.

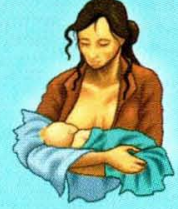

Evite oferecer cha e café junto ou próximo is refeiçóes, pois estas bebidas prejudicam a absorção do rerro.

Näo substitua o almoģo e o jantar pela mamadeira.

- leite deve ser oferecido no café da manhä e no intervalo entre as refeiçóes.

LEMBRE-SE: S6 com a sua ajuda, o Governo do Estado de Säo Paulo poderá vencer essa terrivel doença e assion, garantir a sacide e um futuro feliz para sew mellho.

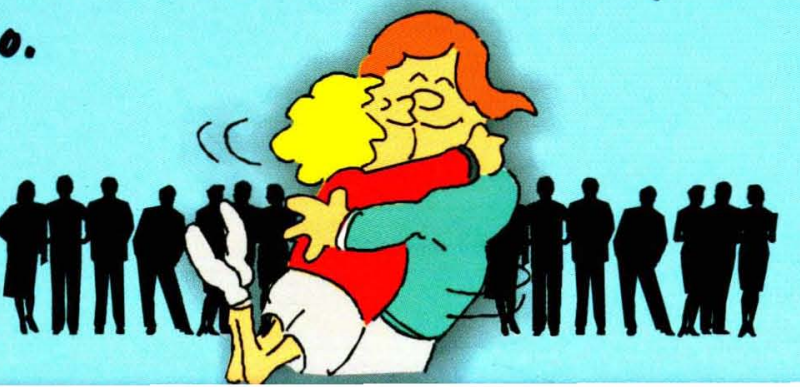


